\title{
New Insights on the Sequence Stratigraphic Architecture of the Dakota Formation in Kansas-Nebraska-Iowa from a Decade of Sponsored Research Activity
}

\author{
Greg A. Ludvigson, Kansas Geological Survey, The University of Kansas, Lawrence, KS \\ Brian J. Witzke, Iowa Geological Survey, Iowa Department of Natural Resources, Iowa City, IA \\ R. M. Joeckel, Nebraska Conservation and Survey Division, School of Natural Resources, The University of \\ Nebraska-Lincoln, Lincoln, NE \\ Robert L. Ravn, The IRF Group, Anchorage, AK \\ Preston Lee Phillips, Department of Geology and Geography, University of North Carolina at Pembroke, Pembroke, NC \\ Luis A. González, Department of Geology, The University of Kansas, Lawrence, KS \\ Robert L. Brenner, Department of Geoscience, The University of Iowa, Iowa City, IA
}

\begin{abstract}
The Cretaceous Dakota Formation in the areas of Kansas, Nebraska, and Iowa contains a rich and well-preserved microflora of fossil palynomorphs. A comprehensive listing of these taxa is presented in this publication as part of a continuing effort to develop a refined biostratigraphic scheme for mid-Cretaceous terrestrial deposits in North America. The Dakota Formation in this region contains four distinctive Albian-Cenomanian palynostratigraphic zones that are used to partition the unit into successive depositional cycles, and each zone records deposition in fluvial-estuarine environments. The late Albian Kiowa-Skull Creek depositional cycle at the base of the Dakota Formation is recognized throughout the study area, and is also recognized in other parts of the Cretaceous North American Western Interior basin. The overlying newly recognized latest Albian "Muddy-Mowry Cycle" is formally defined for the first time in this paper and correlates with depositional cycles recognized by other workers in other parts of the Western Interior basin. The Cenomanian lower Greenhorn Cycle is already widely recognized by many other workers throughout the Western Interior basin. Laterally extensive thin zones of pervasive carbonate mineral cementation are noted in fluvial-estuarine deposits in the Dakota Formation. They are believed to have formed as synsedimentary cements that precipitated below estuarine marine-flooding surfaces in settings related to discharging paleoground waters. The existence of these early diagenetic cementation zones has important implications for the recognition of diagenetic barriers and baffles to modern fluid flow in the Dakota Formation. New stable isotopic data on these authigenic cements are reported in this paper and add to a body of published data on the $\delta^{18} \mathrm{O}$ of mid-Cretaceous paleoprecipitation in North America.
\end{abstract}




\title{
New Insights on the Sequence Stratigraphic Architecture of the Dakota Formation in Kansas-Nebraska-Iowa from a Decade of Sponsored Research Activity
}

\author{
Greg A. Ludvigson, Kansas Geological Survey, The University of Kansas, Lawrence, KS \\ Brian J. Witzke, Iowa Geological Survey, Iowa Department of Natural Resources, Iowa City, IA \\ R. M. Joeckel, Nebraska Conservation and Survey Division, School of Natural Resources, The University of \\ Nebraska-Lincoln, Lincoln, NE \\ Robert L. Ravn, The IRF Group, Anchorage, AK \\ Preston Lee Phillips, Department of Geology and Geography, University of North Carolina at Pembroke, Pembroke, NC \\ Luis A. González, Department of Geology, The University of Kansas, Lawrence, KS \\ Robert L. Brenner, Department of Geoscience, The University of Iowa, Iowa City, IA
}

\section{Introduction}

In 1994, a long-term research program to investigate the stratigraphy of the Cretaceous Dakota Formation in Iowa and immediate environs (Brenner et al., 1981; Witzke and Ludvigson, 1982, 1987, 1994; Witzke et al., 1983; Ravn and Witzke, 1994, 1995) was geographically expanded to include exposures and research drillcores in Nebraska and Kansas, under the auspices of NSF grant number EAR-9628128. This research program included 1) systematic collection, identification, and correlation of palynostratigraphic samples, with the goal of improving biostratigraphic and chronostratigraphic resolution in the interval, and 2) systematic collection of stable isotope paleoclimate proxy data to address the mid-Cretaceous climate-change record contained within the Dakota Formation.

Initial major findings on the regional stratigraphy of the Dakota Formation were published by Brenner et al. (2000). They showed that strata of the Dakota Formation, as originally defined by Meek and Hayden (1862) from its type region in the Missouri River valley (fig. 1), include Albian units that are time-stratigraphic correlates to the marine shales of the Kiowa Formation in Kansas, and Cenomanian units that are time-stratigraphic cor- relates to the Graneros marine shale in Colorado (fig. 2). Brenner et al. (2000) partitioned the Dakota Formation into three major sedimentary sequences bounded by correlative unconformities $\left(\mathrm{D}_{0}, \mathrm{D}_{1}\right.$, and $\left.\mathrm{D}_{2}\right)$, correlations that were based on recognition of four palynostratigraphic zones (fig. 3). This report presents a more complete discussion of the palynostratigraphy of the Dakota Formation, with updated information on the stratigraphic ranges of some key palynologic taxa.

Published findings on the stable isotope paleohydrology and paleoclimatology of the Dakota Formation have described work on pedogenic sphaerosiderites from paleosols (Ludvigson et al., 1998c; White et al., 2001; Ufnar et al., 2002, 2004a, 2004b; White et al., 2005). Concomitant works on other terrestrial stable isotope proxies from the unit are just beginning to emerge in the peer-reviewed scientific literature (see Ufnar et al., 2004a; Phillips et al., 2007). One important facet of this emerging work pertains to the field recognition of early diagenetic cementation of high-frequency (i.e. parasequence) boundaries in estuarine facies of the Dakota Formation. We present previously unpublished results on this topic in this report.

\section{Palynofloras of the Dakota Formation}

Mid-Cretaceous sediments of the midcontinent, as in much of North America, contain extraordinarily rich and well-preserved fossil palynomorphs. Through much of the region, these populations are dominated by the spores and pollen of terrestrial plants, reflecting the mid-Cretaceous seaway regression that punctuated Albian-Cenomanian time. These microfossils record a biostratigraphic succession of great utility for correlation and age interpretation. Detailed documentation of the regional AlbianCenomanian microfloral succession is in preparation and is beyond the scope of this publication, but a number of key forms are illustrated here, and some brief comments on their significance are in order.

Numerous comparative studies are valuable in assessing the ages of strata examined in the region. In the immediate area, the publications of Pierce (1961) from Minnesota, Ward (1986) from Kansas, and Ravn and Witzke $(1994,1995)$ from Iowa are especially relevant. From surrounding areas, the studies of Brenner (1963), Singh (1964, 1971, 1983), Hedlund (1966), Norris (1967), Agasie (1969), Playford (1971), Phillips and Felix (1972a, 1972b), Romans (1975), Srivastava (1977), Wingate (1980), Nichols and Jacobson (1982), and Ravn (1995) are especially useful. Overall, the assemblages and succession from nearby areas are well documented, and a record of the palynostratigraphy from this area central to the Cretaceous midcontinent seaway is of great value in interrelating these earlier studies.

The taxa illustrated in plates 1 and 2 are from numerous localities in Kansas, Nebraska, Iowa, and South Dakota, and represent characteristic material from strata of late Albian through Cenomanian age. Of particular interest for Albian-age interpretation are the fern-related spore species Plicatella jansonii (Pocock) Dörhöfer 1977, Plicatella unica (Markova) Dörhöfer 1977, Impardecispora marylandensis (Brenner) Venkatachala et 


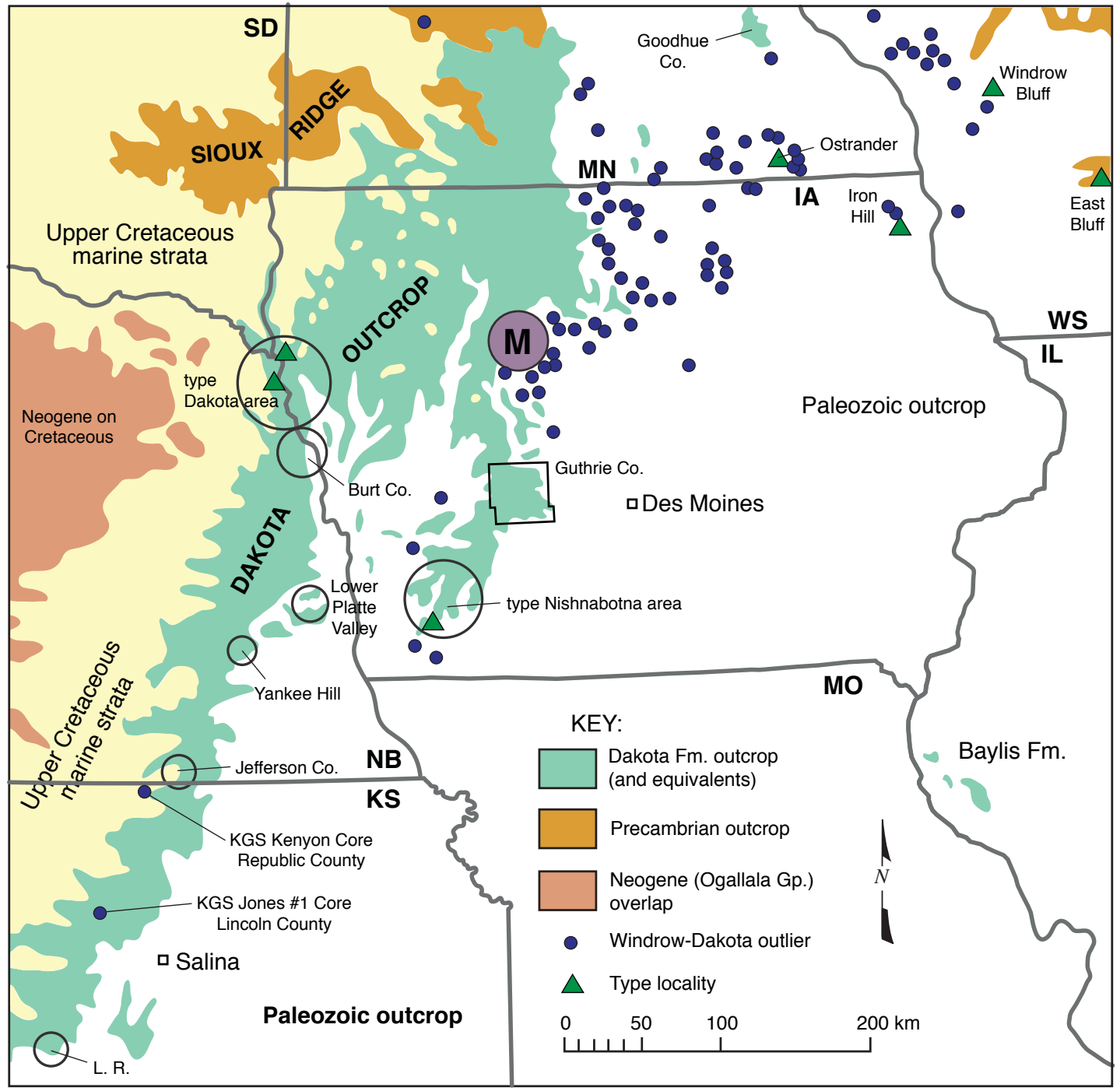

FIGURE 1 -Generalized regional outcrop map of the Dakota Formation and equivalent strata between southern Minnesota (MN) and northern Kansas (KS). Blue-green-colored outcrop denotes the Dakota Formation in western Iowa (IA) and eastern Nebraska (NB), the Dakota and Kiowa Formations in Kansas, and equivalent units in Minnesota. Eastern outliers (dots) include the Dakota Formation in Iowa; the Windrow Formation in Iowa, Wisconsin (WS), and Minnesota; and the Baylis Formation in western Illinois (IL). Cretaceous strata lap the margins of the Sioux Ridge, a long-lived paleotopgraphic feature composed of resistant Precambrian Sioux Quartzite. General study areas are circled and labeled. Guthrie County, Iowa, is outlined. Abbreviations: L.R. - Little River; M - Manson Impact Structure (of late Campanian age). State boundaries are dashed. From Ludvigson and Witzke (1996).

al. 1969 (not illustrated), Impardecispora apiverrucata (Couper) Venkatachala et al. 1969, Impardecispora excavata Ravn 1995, the gymnospermous pollen species Nicholsipollis mimas Ravn 1995, and the angiospermous pollen species Quadricolpites reticulatus Wingate 1980, all of which appear to be restricted in the region to Albian strata. Species appearing to be restricted to Cenomanian strata include Microreticulatisporites sacalii (Deák \& Combaz) Ravn 1986, Lycopodiacidites arcuatus Hedlund 1966, and Cicatricosisporites crassiterminatus Hedlund 1966.
The other taxa illustrated have observed ranges spanning various portions of late Albian and Cenomanian strata in the region.

Also of note is the presence of the gymnospermous pollen grain designated here as Jiaohepollis $\mathrm{n}$. sp. (formal description of this new species is in preparation). As far as we know this report documents the first known occurrence of pollen corresponding to this genus in North America. The genus is originally based on species described from strata of earlier Cretaceous age in China.

\section{Palynostratigraphy and Correlation of the Dakota Formation in the Type Area, Iowa, Nebraska, and Kansas}

The Dakota Formation of Iowa, Nebraska, and Kansas contains one of the most diverse mid-Cretaceous palynofloras known anywhere in the world. The mid-Cretaceous was a remarkable time for the evolution of plant communities in a greenhouse world. This interval was marked by the literal blossoming and explosive radiation of the angiosperms, one of the most important episodes in the history of life on earth. Abundant and well-preserved palynomorph assemblages have been routinely recovered 




\begin{tabular}{|lcl|}
\hline Lignite & r Red Mottling & - Palynomorphs \\
Sandstone & s Spherosiderite & - Marine Mollusks \\
\hline Mudstone & m. Marine Palynomorphs & क Burrows \\
& x Bentonite & - Carbonaceous leaves \\
& i Pedogenic Fabrics & \\
\hline
\end{tabular}

FIGURE 2-Regional cross section of the Dakota Formation and temporal equivalents denoting three unconformity-bounded sequences based on lithostratigraphy and the palynostratigraphy outlined in this report. Graphic logs in study areas are based on measured sections, archived drillcores, well $\operatorname{logs}$, and composites of these as noted. Solid lines represent sequence boundaries $\left(\mathrm{D}_{0}, \mathrm{D}_{1}, \mathrm{D}_{2}\right)$; dashed lines represent major facies boundaries. From Brenner et al. (2000).

from unoxidized lignitic and mudrock units in the formation, and these samples have provided the primary basis for correlation of the Dakota Formation, a predominantly nonmarine sedimentary succession. Palynostratigraphy became essential for correlating strata within the Dakota Formation, as the better-known and more refined Cretaceous marine biostratigraphy (based on mollusks, foraminifera, nannofossils) is largely inapplicable to the nonmarine facies succession that comprises the bulk of the formation.

Initial reports of the rich palynofloras in the Dakota type area were based on assemblages derived primarily from upper Dakota strata of western Iowa, and these floras provided evidence for a lower to middle Cenomanian correlation of these strata (Ravn, 1981; Ravn and Witzke, 1994, 1995). These reports suggest that lower Dakota strata in the type area are most likely of Albian age, but sampling was inadequate to fully demonstrate an Albian correlation at that time. Renewed sampling during the 1990s and early 2000s resulted in the recovery of rich palynomorph assemblages from lower Dakota strata in Iowa, Nebraska, and Kansas that contained well-defined Albian palynofloras. Preliminary assessments of lower Dakota palynostratigraphy were presented by Witzke, Ravn, et al. (1996), Witzke, Ludvigson, Ravn, et al. (1996), and Witzke and Ludvigson (1998), but the full taxonomic listing of the constituent palynofloras and their biostratigraphic significance have not yet been presented. Additions and corrections to the four-part biostratigraphic scheme proposed for the Dakota Formation by Witzke, Ravn, et al. (1996) and Witzke, Ludvigson, Ravn, et al. (1996) are noted in this paper. Within the context of these four biostratigraphic subdivisions (units 1-4), all identified palynotaxa recovered from the Dakota Formation of Iowa, Nebraska, and Kansas are listed here for the first time. Publication of the full systematic treatment of these palynofloras with locational and stratigraphic details must await further study.

Numerous leaf-compression floras also have been discovered in the Dakota Formation of Iowa, Kansas, and Nebraska, but only a few of these have been studied (e.g., Upchurch and Dilcher, 1990). All known compression floras are dominated by angiosperms (especially platinoids and magnoliaceans at most localities), but fern and gymnosperm (taxodiacean) compressions are also known. By contrast, the Dakota palynofloras are dominated by pteridophyte (fern) spores, probably because the angiosperms are relatively stingy in their production of pollen. The biological relationships of most Cretaceous palynotaxa are known with varying degrees of confidence, but absolute certainty of these relationships requires exceptional preservation of palynomorphs as- 


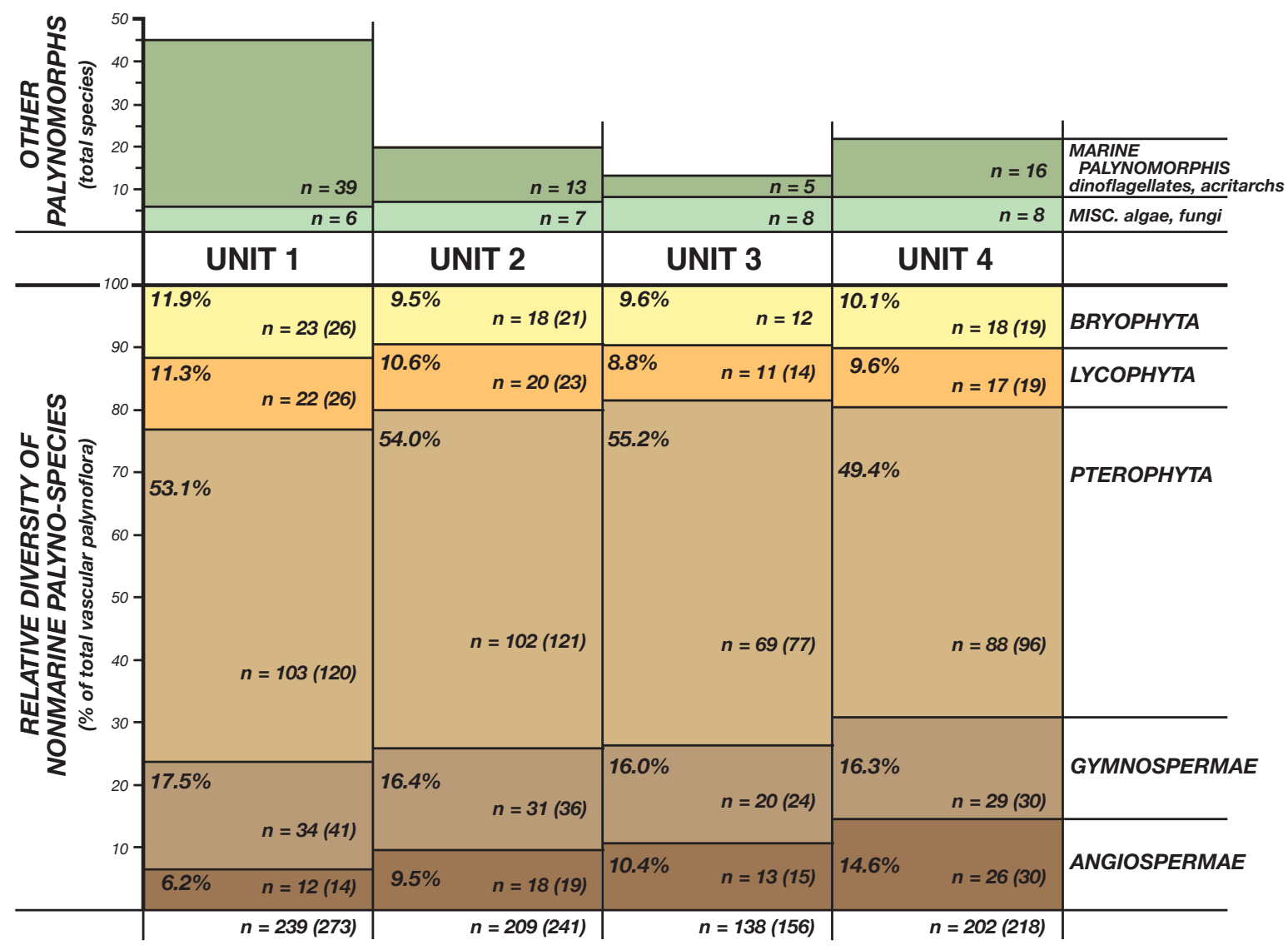

FIGURE 3-Relative palynospecies diversity within major vascular plant groups in Dakota palynostratigraphic units 1 through 4 (\% of total vascular palynoflora for each unit). Data tabulated from tables 1-7. A relative increase in angiosperm-pollen diversity through the Dakota succession is recognized. Absolute diversity of other algal, fungal, and marine palynomorph species is also shown. $\mathrm{n}-$ total number of species identified (number in parentheses includes additional unidentified species).

sociated with reproductive bodies of known plant compressions. The accompanying tables (tables 1-4) are intended to list spore and pollen taxa according to their most likely relationships with major plant groups. In some cases, these relationships are not clearly known or are controversial. For example, although Foveosporites and Reticulatisporites are listed with the pteridophytes, some authors have suggested relationships with lycophytes or bryophytes, respectively. Regardless, the pteridophyte dominance of the Dakota palynofloras remains evident (fig. 3).

Pteridophyte taxa include probable representatives of the osmundaceans, schizaeaceans, gleicheniaceans, matoniacaeans, marsiliaceans, polypodiaceans, and others. Water ferns and tree ferns likely are represented. Bryophyte (mosses and liverworts) and lycophyte (lycopods and selaginellaceans) spores also are abundant and diverse in the Dakota assemblages. Fungal hypha and algal spores are present in many assemblages.

Pollen grains from gymnosperms and angiosperms generally are less abundant than the pteridophytes, but the diversity of these forms is notable. Gymnosperm pollen suggests the presence of pines, podocarps, taxodiaceans, and araucariaceans in the region. Additional gymnosperms include cycadophytes, various incertae sedis, and certain "advanced" gymnosperms (gnetaleans, erdtmanithecales). The diversity of gymnosperm pollen, however, is not reflected in the Dakota compression floras, perhaps suggesting that many palynotaxa were part of the regional pollen rain. Angiosperm pollen shows an overall increase in diversity and complexity upward through the Dakota Formation (fig. 3), the only significant stratigraphic change in diversity through the Dakota succession. This increase in diversity likely reflects part of the ongoing mid-Cretaceous explosive angiosperm radiation. The biological relationships of many of the Dakota angiosperm pollen taxa remain problematic. Primitive angiosperms are included in the floras (e.g., Asteropollis). Compression floras suggest that the angiosperms were dominated by forms with magnoliacean and platinoid leaf types, but a variety of other types are also present.

The floral composition and sedimentary character of the Dakota Formation indicate humid subtropical to warm temperate climates in the region during the mid-Cretaceous. Abundant mosses and lycophytes suggest that wet habitats were common in the Dakota depositional environments. The common occurrence of algal spores is especially noteworthy, indicating that wetland and ponded settings were common in the Dakota depositional systems. Sedimentary features, including sideritic paleosols (saturated wetland soils), kaolinitic mudstones (indicative of humid weathering), and abundant lignites and carbonaceous shale (swampy wetlands), all support moist to wet environments during most or all of Dakota deposition. Of note, there are no sedimentary features suggesting arid or dry conditions (e.g., calcareous paleosols). Nevertheless, large vertical features within some plinthic paleosols and the presence of tree rings in wood indicate seasonality, probably resulting from changes between wetter and drier seasonal cycles. Overall, the Dakota environments probably were characterized by heavily vegetated, moist to swampy forests that covered much of the expansive low-lying coastal plain along 
TABLE 1 -Dakota Palynostratigraphic Unit 1; early Late Albian; Cass, Sarpy, Jefferson counties, Nebraska; Guthrie County, Iowa; Stanton, Lincoln counties, Kansas; identifications by Robert L. Ravn. Biostratigraphically significant taxa (first or last occurrence) are underlined. Those taxa that are restricted to the palynostratigraphic unit are shown in bold type.

\begin{tabular}{|c|c|c|c|}
\hline BRYOPHYTA & Cicatricosisporites apicanalis & I. sp. indet. & C.torosa \\
\hline Aequitriradites spinulosus & C. aralicus & Laevigatosporites gracilis & Cycadopites nitidus \\
\hline Chomotriletes minor & C. australiensis & L. haardtii & C.sp. indet. \\
\hline Contignisporites glebulentus & $\underline{\text { C.claricanalis }}$ & L. ovatus & Equisetosporites concinnus \\
\hline C. sp. & C.goniodontos & L. sp. (large) & E. sp. indet. \\
\hline Couperisporites complexus & C.cf. hughesii & Lobatia involucrata & Eucommiidites minor \\
\hline C. tabulatus & C.cf. ludbrooki & Lophotriletes babsae & $\overline{\text { E.troedssonii }}$ \\
\hline Foraminisporis asymmetricus & C.mediostriatus & Microfoveolatisporis sp. indet. & E.? sp. \\
\hline F. wonthaggiensis & C. minutaestriatus & Microreticulatisporites sacalii & Exesipollenites scabratus \\
\hline Interulobites exuperans & C.patapscoensis & M. uniformis & E.tumulus \\
\hline I. intraverrucatus & C.potomacensis & M.? sp. indet. & E.? sp. \\
\hline$\overline{\text { I. cf. triangularis }}$ & C.psuedotripartitus & Neoraistrickia robusta & Inaperturopollenites pseudoreticu- \\
\hline I. sp. indet. & C.cf. spiralis & N.truncata & latus \\
\hline Polycingulatisporites reduncus & C.cf. stoveri & Nevesisporites simiscalaris & Jiaohepollis flexuosus \\
\hline Rogalskaisporites cicatricosus & C.venustus & Nodosisporites stellantis & Laricoidites magnus \\
\hline Stereigranisporis regius & C. cf. venustus of Ravn, 1995 & $N$. spp. indet. & Monosulcites minimus \\
\hline Stereisporites antiquasporites & $C$. spp. indet. & Ornamentifera echinata & Nicholsipollis mimas \\
\hline S.psilatus & Cingulatisporites cf. levispeciosus & Osmundacidites wellmanii & Parvisaccites radiatus \\
\hline$S$. sp. indet. & C.? sp. indet. & Pilosisporites cf. notensis & Piceaepollenites sp. indet. \\
\hline Taurocusporites segmentatus & Concavissimisporites granulosus & P.trichopapillosus & Pinuspollenites constrictus \\
\hline Triporoletes cenomanianus & C.punctatus & $P$. spp. indet. & Podocarpidites multesimus \\
\hline T. laevigatus & C.cf. variverrucatus & Plicatella cristata & P.cf.potomacensis \\
\hline$\underline{\text { T. radiatus }}$ & Converrucosisporites sp. indet. & P.cf.fucosa & $P$. sp. indet. \\
\hline T. reticulatus & Corniculatisporites sp. indet. & $\underline{\text { P.jansonii }}$ & Pristinuspollenites inchoatus \\
\hline T. simplex & Costatoperforosporites foveolatus & P. matesovae & P. sulcatus \\
\hline T.sp. 1 & Crybelosporites pannuceus & P.potomacensis & P.cf. microsaccus \\
\hline \multirow[t]{2}{*}{ T.sp. 2} & C. striatus & P.cf. problematica & $P$. sp. indet. \\
\hline & C. sp. indet. & P. tricornitata & Rugubivesiculites reductus \\
\hline LYCOPHYTA & Deltoidospora hallii & P. unica & R.rugosus \\
\hline Camarozonosporites ambigens & D. maculosa & $P$. sp. indet. & R.woodbinensis \\
\hline C.wrenni & D. mesozoica & Plicifera dicarpoides & Steevesipollenites sp. \\
\hline$\overline{C . \mathrm{sp} . \text { (small) }}$ & D. minor & Polypodiisporonites cenomanianus & Taxodiaceaepollenites hiatus \\
\hline Densoisporites circumundulatus & $D$. sp. indet. & Psilatriletes radiatus & Thomsonisporites rasilis \\
\hline D.microrugulatus & Dictyophyllidites cf. harrisii & Punctatisporites couperi & Tsugaepollenites discoides \\
\hline D.velatus & D. cf. impensus & P.globosus & $T$. sp. indet. \\
\hline$\overline{\text { Discisporites discoides }}$ & D. incomptus & $P$. sp. indet. & Vitreisporites pallidus \\
\hline Divisisporites? sp. indet. & $D$. sp. indet. & Reticulosporis elongatus & indet. bisaccate pollen \\
\hline Echinatisporis varispinosus & Disaltriangulisporites irregularis & $R . . \mathrm{sp}$ (large) & \\
\hline E. sp. indet. & D. mutabilis & Reticulatisporites castellatus & ANGIOSPERMAE \\
\hline Kraeuselisporites breviculus & D.perplexus & $\underline{\text { Scopusporis excavatus }}$ & Asteropollis asteroides \\
\hline K. hastilobatus & Extrapunctatosporis pseudoreticu- & $\underline{\text { S. lautus }}$ & Foveomonocolpites sp. indet. \\
\hline Leptolepidites proxigranulatus & $\underline{\text { latus }}$ & S. spackmanii & Fraxinoipollenites constrictus \\
\hline L. verrucatus & Foveogleicheniidites cf. confossus & $S$. sp. indet. & F. venustus \\
\hline L. sp. indet. & Foveosporites labiosus & Stoverisporites lunaris & Liliacidites doylei \\
\hline Lycopodiacidites canaliculatus & F.pantostiktos & Tigrisporites reticulatus & Phimopollenites sp. indet. \\
\hline L. triangularis & F. senomanicus & T. scurrandus & Quadricolpites reticulatus \\
\hline L. wardii & F. subtriangularis & T. verrucatus & Retimonocolpites dividuus \\
\hline$L$. sp. indet. & $F$. sp. indet. & Tribosporites canadensis & $R$. sp. indet. \\
\hline Retitriletes austroclavatidites & Gleicheniidites senonicus & Undulatisporites pannuceus & Rousea sp. indet. \\
\hline R. reticulumsporites & $G$. sp. (small, thick) & U. undulapolus & $R . ? \mathrm{sp}$. (strongly prolate) \\
\hline R. cf. saltimaniolus & Granulatisporites michinus & $U . ?$ sp. indet. & Sabalpollenites scabrus \\
\hline R. singhii & G.? sp. indet. & Verrucosisporites conspicuus & Tricolpites sp. indet. \\
\hline$R$. spp. indet. & Impardecispora apiverrucata & V. rotundus & Verrumonocolpites sp. indet. \\
\hline Sestrosporites pseudoalveolatus & I. excavata & $V$. sp. indet. & \\
\hline \multirow[t]{2}{*}{$\underline{\text { Staplinisporites caminus }}$} & I. marylandensis & & MISCELLANEA \\
\hline & I. minor & GYMNOSPERMAE & Lecaniella foveata \\
\hline PTEROPHYTA & I. purverulenta & Abietineaepollenites sp. indet. & Ovoidites australiensis \\
\hline Antulsporites distaverrucosus & I.? sp. indet. & Araucariacites cf. australis & O. majusculus \\
\hline A. sp. (invag. angles) & Ischyosporites crassimacerius & Balmeiopsis limbatus & O.parvus \\
\hline Balmeisporites holodictyus & $\underline{\text { I. disjunctus }}$ & Callialasporites dampieri & $O . ? \mathrm{sp}$. \\
\hline Biretisporites potoniei & I. foveolatus & Cedripites canadensis & Schizosporis reticulatus \\
\hline Cibotiumspora juncta & I. pseudoreticulatus & $\overline{\text { Corollina echinata }}$ & linear septate fungal hypha \\
\hline
\end{tabular}


TABLE 2-Dakota Palynostratigraphic Unit 2; latest Albian; Lancaster, Jefferson, Burt counties, Nebraska; Stanton County, Kansas; Woodbury County, Iowa; identifications by Robert L. Ravn. Biostratigraphically significant taxa (first or last occurrence) are underlined. Those taxa that are restricted to the palynostratigraphic unit are shown in bold type.

\begin{tabular}{|c|c|c|c|}
\hline BRYOPHYTA & C.goniodontos & Lophotriletes babsae & Jiaohepollis flexuosus \\
\hline Aequitriradites spinulosus & C. cf. hughesi & L. sp. & Laricoidites magnus \\
\hline Cingulatisporites? sp. & C.mediostriatus & Microfoveolatisporis sp. indet. & Nicholsipollis mimas \\
\hline Contignisporites glebulensis & C. minutaestriatus & Microreticulatisporites sacalii & Parvisaccites radiatus \\
\hline C. sp. & C.patapscoensis & M. uniformis & Piceaepollenites sp. \\
\hline Couperisporites tabulatus & C.potomacensis & M. sp. & Pinuspollenites constrictus \\
\hline Foraminisporis asymmetricus & C.pseudotripartitus & Neoraistrickia robusta & Podocarpidites multesimus \\
\hline F. wonthaggiensis & C.cf. sprumontii & N. truncata & $P$. sp. indet. \\
\hline Interulobites intraverrucatus & C. venustus & Nodosisporites stellantis & Pristinuspollenites inchoatus \\
\hline Interulobites cf. triangularis & C.cf. venustus & $N . \mathrm{sp}$. & P.pannosus \\
\hline Nevesisporites simiscalaris & C. spp. indet. & Ornamentifera echinata & P. sulcatus \\
\hline Polycingulatisporites reduncus & Concavissimisporites granulosus & Osmundacidites wellmanii & $P$. sp. \\
\hline Stereisporites psilatus & C. punctatus & Petalosporites quadrangulus & Rugubivesiculites reductus \\
\hline$S$. sp. indet. & C. cf. veriverrucalus & Pilosisporites cf. notensis & R.rugosus \\
\hline Taurocusporites segmentatus & Converrucosisporites sp. & P.trichopapillosus & R.woodbinensis \\
\hline Triporoletes cenomanianus & Corniculatisporites sp. & $P$. sp. & Steevesipollenites sp. \\
\hline T. laevigatus & Costatoperforosporites foveolatus & Plicatella cristata & Taxodiaceaepollenites hiatus \\
\hline T. pluricellulus & Crybelosporites bursatus & P.cf.ethmos & Thomsonisporites rasilis \\
\hline$\underline{\text { T. radiatus }}$ & C.pannuceus & $P$. cf. fucosa & $T$. sp. \\
\hline T. reticulatus & C. striatus & $\underline{\text { P.jansonii }}$ & Triquitrites sculptilis \\
\hline T. simplex & $C . \mathrm{sp}$. & P. matesovae & Tsugaepollenites sp. indet. \\
\hline \multirow[t]{2}{*}{ T. sp. } & Deltoidospora hallii & $\overline{\text { P.potomacensis }}$ & Vitreisporites pallidus \\
\hline & D. cf. maculosa & P.cf. problematica & \\
\hline LYCOPHYTA & D. mesozoica & P. tricornitata & ANGIOSPERMAE \\
\hline Camarozonosporites ambigens & D. minor & P. unica & Cupuliferoidaepollenites minutus \\
\hline C. anulatus & D. sp. 1 & $P$. sp. indet. & Foveomonocolpites sp. indet. \\
\hline C. wrenni & $D$. sp. indet. & Plicifera dicarpoides & Fraxinoipollenites constrictus \\
\hline Densoisporites circumundulatus & Dictyophyllidites impensus & Polypodiisporonites? morulus & F. venustus \\
\hline D.microrugatulus & D. incomptus & Psilatriletes radiatus & Liliacidites doylei \\
\hline D. velatus & D. cf. equiexinous & Punctatisporites couperi & Palmaepollenites asymmetricus \\
\hline Discisporites sp. & D. cf. harrisii & P. globulosus & Penetetrapites sp. \\
\hline ?Divisisporites $\mathrm{sp}$. & D. cf. trianguliformis & P. sp. & Phimopollenites sp. \\
\hline Echinatisporis varispinosus & $D$. sp. indet. & Reticulisporis elongatus & Psilatricolporites $\mathrm{sp}$. \\
\hline E. sp. & Disaltriangulisporites mutabilis & $R$. sp. & Retimonocolpites dividuus \\
\hline Endosporites globiformis & D.perplexus & Scopusporis excavatus & $R . \mathrm{sp}$. \\
\hline Kraeuselisporites breviculus & Extrapunctatosporis pseudoreticulatus & S. lautus & Rousea sp. \\
\hline K. hastilobatus & Foveogleicheniidites $\mathrm{cf}$ confossus & S. spackmanii & Quadricolpites reticulatus \\
\hline Leptolepidites sp. & Foveosporites pantostiktos & S. sp. & Quercoidites? sp. \\
\hline Lycopodiacidites canaliculatus & F.cf.labiosus & Tigrisporites reticulatus & Sabalpollenites scabrus \\
\hline L. triangularis & F.cf. senomanicus & T. scurrandus & Stellatopollis barghoornii \\
\hline L. wardii & F. subtriangularis & T. verrucatus & S. largissimus \\
\hline L. sp. & $F$. sp. indet. & Trilobosporites canadensis & Tricolpites sagax \\
\hline Retitriletes austroclavatidites & "Foveoaletes" sp. & Undulatisporites pannuceus & Verrumonocolpites sp. \\
\hline R. singhii & Gleicheniidites senonicus & $U . \mathrm{sp}$. indet. & \\
\hline$R . \mathrm{sp}$. & G. sp. & Verrucosisporites rotundus & MISCELLANEA \\
\hline Sestrosporites pseudoalveolatus & Granulatisporites michinus & $V$. sp. indet. & Multicellaesporites sp. \\
\hline \multirow[t]{2}{*}{$\underline{\text { Staplinisporites caminus }}$} & G. sp. & & Ovoidites australiensis \\
\hline & Impardecispora apiverrucata & GYMNOSPERMAE & O. majusculus \\
\hline PTEROPHYTA & I. excavata & Abietineaepollenites sp. & O.parvus \\
\hline Antulsporites distaverrucosus & I. marylandensis & Auracariacites australis & $O . \mathrm{sp}$ \\
\hline A. sp. & I. minor & Balmeiopsis limbatus & Schizosporis reticulatus \\
\hline Arcellites disciformis & I. purverulenta & Callialasporites dampieri & Tetraporina? sp. \\
\hline Baculatisporites camaumensis & I. trioreticulosa & Cedripites canadensis & linear septate fungal hypha \\
\hline Balmeisporites glenelgensis & Ischyosporites pseudoreticulatus & Corollina echinata & \\
\hline B. holodictyus & I. cf. crassimacerius & C. torosa & \\
\hline Biretisporites potoniei & $\underline{\text { Januasporites spiniferus }}$ & Cycadopites sp. indet. & \\
\hline Cibotiumspora juncta & Laevigatosporites foveolatus & Equisetosporites concinnus & \\
\hline Cicatricosisporites apicanalis & L. gracilis & E.sp. & \\
\hline C. aralicus & L. haardtii & Eucomiidites troedssonii & \\
\hline C.australiensis & L. ovatus & $\overline{\text { Exesipollenites tumulus }}$ & \\
\hline C. claricanalis & L. sp. & E. sp. & \\
\hline C. cf. dorogensis & Lobatia involucrata & Florinites visendus & \\
\hline
\end{tabular}


the eastern margin of the Western Interior seaway. These forests were probably marked by small to large trees of gymnosperms and angiosperms with a dense understory of ferns. Many angiosperms likely grew as small trees, shrubs, and vines in these environments.

\section{Dakota Palynostratigraphic Units}

Four biostratigraphic units are recognized within the Dakota succession of Iowa, Nebraska, and Kansas, as discussed herein. These units provide a relatively coarse biostratigraphic scheme, especially when compared with the more detailed coeval marine zonation based on ammonites, inoceramids, and foraminifera (e.g., Kauffman et al., 1993). Nevertheless, the Dakota palynostratigraphic scheme has enabled general correlation of the terrestrial, fluvial, and estuarine facies of the Dakota Formation within the context of the Albian-Cenomanian depositional cycles of the Western Interior. The three major stratigraphic sequences represented within the Dakota succession (Brenner et al., 2000) can now be correlated and identified using this palynostratigraphic scheme. The accompanying tables (tables 1-4) summarize all nonmarine palynotaxa recognized within the Dakota Formation of the region. These units are remarkably diverse, each containing between 130 and 200 nonmarine species. Depending on how certain indeterminate species are tabulated, the actual recovered diversities may be much higher (perhaps as high as 230 species in units 1 and 2). Many taxa on these lists are long-ranging forms of limited biostratigraphic utility, and many taxa span all four Dakota palyno-units. However, each unit contains a number of palynomorphs of biostratigraphic significance (most are underlined or highlighted on the accompanying tables), marking important first or last occurrences in the succession and providing a basis for local, regional, and inter-regional correlation. The Dakota Formation is further constrained by its bounding and lateral stratigraphic relationships with marine shale and marl units of the Kiowa, Graneros, and Greenhorn formations.

TABLE 3-Dakota Palynostratigraphic Unit 3; Early Cenomanian; Woodbury, Sioux counties, Iowa; Jefferson, Burt, Thurston counties, Nebraska; identifications by Robert L. Ravn. Biostratigraphically significant taxa (first or last occurrence) are underlined. Those taxa that are restricted to the palynostratigraphic unit are shown in bold type.

\begin{tabular}{|c|c|c|c|}
\hline BRYOPHYTA & Cicatricosisporites australiensis & L. ovatus & Podocarpidites multesimus \\
\hline Aequitriradites spinulosus & C.cf. dorogensis & Lobatia involucrata & $P . \mathrm{sp}$. \\
\hline Annulispora sp. & C.hallei & Microreticulatisporites sacalii & Pristinuspollenites inchoatus \\
\hline Chomotriletes minor & C. cf. imbricatus & M. uniformis & P. cf. microsaccus \\
\hline Foraminisporis wonthaggiensis & C.cf. imbricatus & $M . \mathrm{sp}$. & P. sulcatus \\
\hline Polycingulatisporites reduncus & C.mediostriatus & Multicellaesporites sp. & $P$. sp. indet. \\
\hline Stereisporites psilatus & C.pseudotripartitus & Neoraistrickia robusta & Rugubivesiculites convolutus \\
\hline Taurocusporites segmentatus & C.venustus & Nodosisporites stellantis & R. reductus \\
\hline Triporoletes cenomanianus & C.cf. ludbrooki & Osmundacidites wellmanii & R.rugosus \\
\hline T. laevigatus & C. spp. indet. & Peromonolites cf. allanensis & Steevesipollenites cf. binodosus \\
\hline T. pluricellulus & Cingulatisporites cf. levispeciosus & Petalosporites quadrangulus & Taxodiaceaepollenites hiatus \\
\hline T.reticulatus & Concavissimisporites punctatus & Pilosisporites trichopapillosus & Tsugaepollenites sp. indet. \\
\hline$\underline{\text { T. simplex }}$ & $\begin{array}{l}\text { Converrucosisporites } \mathrm{sp} \text {. indet. } \\
\text { Costatoperforosporites foveolatus }\end{array}$ & $\begin{array}{l}\text { Plicatella cristata } \\
\text { P. ethmos }\end{array}$ & Vitreisporites pallidus \\
\hline LYCOPHYTA & Crybelosporites bursatus & P.potomacensis & ANGIOSPERMAE \\
\hline Camarozonosporites ambigens & C.pannuceus & P. tricornitata & $\underline{\text { Artiopollis indivisus }}$ \\
\hline C. anulatus & C. striatus & P. unica & Cupuliferoidaepollenites minutus \\
\hline Densoisporites circumundulatus & Deltoidospora hallii & P. witzkei & Echimonocolpites spinosus \\
\hline Discisporites? sp. & D. mesozoica & $P$. sp. indet. & Foveomonocolpites sp. indet. \\
\hline Echinatisporis varispinosus & D. minor & Plicifera dicarpoides & Fraxinoipollenites constrictus \\
\hline Leptolepidites verrucatus & $D . \mathrm{sp}$. & Polypodiisporonites cenomanianus & Liliacidites doylei \\
\hline L.sp. & Dictyophyllidites harrisii & Psilatriletes radiatus & Penetetrapites mollis \\
\hline Lycopodiacidites arcuatus & D.impensus & Scopusporis excavatus & Phimopollenites sp. indet. \\
\hline L. canaliculatus & D. sp. indet. & Scortea cf. diaphana & Psilatricolporites sp. \\
\hline L. wardii & Foveogleicheniidites confossus & S. cf. tecta & Sabalpollenites scabrus \\
\hline L.wrennii & Foveosporites cenomanianus & Tigrisporites reticulatus & S.cf. scabrus (small) \\
\hline L. sp. & F. subtriangularis & Wilsonisporites coronarius & Stellatopollis barghoornii \\
\hline Retitriletes austroclavatidites & Gleicheniidites senonicus & & S. largissimus \\
\hline \multirow[t]{2}{*}{$R . \mathrm{sp}$} & Granulatisporites michinus & GYMNOSPERMAE & Tricolpites vulgaris \\
\hline & Impardecispora marylandensis & Balmeiopsis limbatus & $T$. sp. indet. \\
\hline PTEROPHYTA & I. purverulenta & Callialasporites dampieri & \\
\hline Antulsporites distaverrucosus & I. trioreticulosa & Corollina torosa & MISCELLANEA \\
\hline Arcellites disciformis & $I . \mathrm{sp}$. & Cycadopites fragilis & Inapertisporites $\mathrm{sp}$. \\
\hline Baculatisporites comaumensis & Ischyosporites crassimacerius & C. sp. & Lecaniella? sp. \\
\hline Balmeisporites glenelgensis & I. disjunctus & Equisetosporites sp. & Ovoidites australiensis \\
\hline B. holodictyus & I.pseudoreticulatus & Jiaohepollis cf.flexиоsиs & O.majusculus \\
\hline$B . \mathrm{sp}$. & I. sp. indet. & Nicholsipollis mimas & O.parvus \\
\hline Biretisporites potoniei & Januasporites spiniferus & Parvisaccites radiatus & $O . ? \mathrm{sp}$. \\
\hline Cibotiumspora juncta & Lacrimasporonites sp. & $P . \mathrm{sp}$ & Schizocystia rugosa \\
\hline C. juriensis & $\begin{array}{l}\text { Laevigatosporites gracilis } \\
\text { L. haardtii }\end{array}$ & Piceaepollenites sp. indet. & $\begin{array}{l}\text { Schizosporis reticulatus } \\
\text { linear septate funal hypha }\end{array}$ \\
\hline
\end{tabular}

Current Research in Earth Sciences, Bulletin 258, part 2 (http://www.kgs.ku.edu/Current/2010/Ludvigson/index.html) 
TABLE 4-Dakota Palynostratigraphic Unit 4; Middle Cenomanian; Woodbury, Sioux counties, Iowa; Thurston, Jefferson counties, Nebraska; Lincoln County, Kansas; identifications by Robert L. Ravn. Biostratigraphically significant taxa (first or last occurrence) are underlined. Those taxa that are restricted to the palynostratigraphic unit are shown in bold type.

\begin{tabular}{|c|c|c|c|}
\hline BRYOPHYTA & C. hallei & Osmundacidites wellmanii & $P$. spp. indet. \\
\hline Aequitriradites spinulosus & C.cf. imbricatus & Peromonolites cf. allanensis & Rugubivesiculites convolutus \\
\hline A. cf. echinatus & C.cf.ludbrooki & Petalosporites quadrangulus & R. reductus \\
\hline Annulispora sp. indet. & C.mediostriatus & Pilosisporites trichopapillosus & R.rugosus \\
\hline Chomotriletes minor & C.paradorogensis & Pluricellaesporites sp. & R. woodbinensis \\
\hline Cingulatriletes $\mathrm{cf}$. congruens & C.psuedotripartitus & Plicatella cristata & Steevesipollenites $\mathrm{sp}$. \\
\hline Contignisporites sp. & C. cf. pseudotripartitus (small) & P. ethmos & Taxodiaceaepollenites hiatus \\
\hline Foraminisporis asymmetricus & C.venustus & P. fucosa & Thomsonisporites? sp. \\
\hline F.wonthaggiensis & C. spp. indet. & P.potomacensis & Tsugaepollenites spp. indet. \\
\hline Interulobites distaverrucosus & Cingulatisporites $\mathrm{cf}$. levispeciosus & P. cf.problematica & \\
\hline Polycingulatisporites reduncus & Concavissimisporites punctatus & P. tricornitata & ANGIOSPERMAE \\
\hline Stereigranisporis regius & Converrucosisporites sp. indet. & P. unica & $\underline{\text { Artiopollis indivisus }}$ \\
\hline Stereisporites antiquasporites & Costatoperforosporites foveolatus & P. witzkei & Brenneripollis potomacensis \\
\hline S.psilatus & Crybelosporites bursatus & P. cf. bilateralis & Cupuliferoipollenites minutus \\
\hline$S$. sp. indet. & C.pannuceus & P. cf. concentrica & Cyathidites sp. \\
\hline Taurocusporites segmentatus & C. striatus & P. cf.problematica & Doyleipollenites robbinsiae \\
\hline Triporoletes cenomanianus & Deltoidospora hallii & $P$. sp. indet. & Ephedripites ambiguus \\
\hline T. laevigatus & D. mesozoica & Plicifera dicarpoides & Foveomonocolpites sp. indet. \\
\hline T.pluricellulus & D. minor & Polypodiisporonites cenomanianus & Foveotricolporites rhombohe- \\
\hline \multirow[t]{2}{*}{ T. reticulatus } & D. sp. Ravn, 1995 & Punctatosporites sp. & $\underline{\text { dralis }}$ \\
\hline & Dictyophyllidites harrisii & Scopusporis excavatus & Fraxinoipollenites constrictus \\
\hline LYCOPHYTA & D. impensus & $S$. sp. indet. & $F$. sp. indet. \\
\hline Camarozonosporites ambigens & D. cf. impensus (small) & Scortea diaphana & Liliacidites dividuus \\
\hline C. cf. anulatus & D. sp. indet. & S. cf. tecta & L. doylei \\
\hline C. dakotensis & Dictyotidium? sp. & Tigrisporites reticulatus & Montiapollis hallii \\
\hline C. sp. 1 & Foveogleicheniidites confossus & T. verrucatus & Palmaepollenites asymmetricus \\
\hline Densoisporites circumundulatus & Foveosporites cenomanianus & Undulatisporites pannuceus & Phimopollenites sp. indet. \\
\hline Discisporites sp. & F. senomanicus & U.undulapolus & Psilatricolpites sp. \\
\hline Echinatisporis sp. & F. subtriangularis & Verrucosisporites rotundus & Retimonocolpites dividuus \\
\hline Lycopodiacidites arcuatus & Gleicheniidites senonicus & V. oviformis & Retitricolpites sp. \\
\hline L. canaliculatus & G. sp.1 & Wilsonisporites coronarius & Rousea wilsonii \\
\hline L. wardii & G. sp. 2 & & $R$. sp. indet. \\
\hline L. sp. & Granulatisporites michinus & GYMNOSPERMAE & Sabalpollenites scabrus \\
\hline Lycopodiumsporites crassimacerius & Impardecispora excavata & Araucariacites cf. australis & Senectotetradites cf. varireticu- \\
\hline Perotriletes pannuceus & I. marylandensis & Balmeiopsis limbatus & latus \\
\hline Retitriletes austroclavatidites & I. minor & Callialasporites dampieri & Stellatopollis barghoornii \\
\hline R.expansus & I. purverulenta & Corollina torosa & S. largissimus \\
\hline$R$.. reticulumsporites & I. trioreticulosa & Cycadopites fragilis & $S$. sp. indet \\
\hline R. singhii & I. sp. & Equisetosporites ambiguus & "Stephanocolpites" tectorius \\
\hline$R$. spp. indet. & Inapertisporites sp. indet. & E.concinnus & Tricolpites nemejcii \\
\hline \multirow[t]{2}{*}{ Sestrosporites pseudoalveolatus } & Ischyosporites crassimacerius & E. virginaensis & $\underline{\text { T.patens }}$ \\
\hline & I. estherae & Inaperturopollenites dubius & T. vulgaris \\
\hline PTEROPHYTA & I. pseudoreticulatus & Jiaohepollis cf.flexuosus & $T$. sp. indet. \\
\hline Antulsporites distaverrucosus & I. sp. indet. & Nicholsipollis mimas & \\
\hline Appendicisporites auritus & Laevigatosporites gracilis & Parvisaccites radiatus & MISCELLANEA \\
\hline Arcellites disciformis & L. haardtii & Piceaepollenites sp. indet. & Ariadnaesporites spinocapera- \\
\hline Balmeisporites glenelgensis & L. ovatus & Pinuspollenites sp. & $\underline{t u s}$ \\
\hline B. holodictyus & Leptolepidites sp. indet. & Pityosporites constrictus & $\overline{\text { Lecaniella foveata }}$ \\
\hline$B$. sp. & Microfoveolatisporis pseudoreticulatus & P. granulatus & Ovoidites majusculus \\
\hline Biretisporites potoniei & Microreticulatisporites sacallii & Podocarpidites sp. indet. & O.parvus \\
\hline Cibotiumspora juriensis & M. uniformis & Pristinuspollenites inchoatus & Schizocystia rugosa \\
\hline Cicatricosisporites australiensis & Nodosisporites stellantis & P.pannosus & Schizosporis reticulatus \\
\hline C. crassiterminatus & N. dentimarginatus & P. sulcatus & Spermatites piperiformis \\
\hline C. cf. dorogensis & $N$. sp. indet. & P.cf. microsaccus & Thyodiscus? sp. \\
\hline
\end{tabular}

Unit 1. Dakota Palynostratigraphic Unit 1 directly corresponds to Dakota Sequence $\mathrm{D}_{0}$ of Brenner et al. (2000), a stratigraphic interval that is known to interfinger westward with marine facies of the Kiowa shale. Most palynomorphs were recovered from the lower half of this sequence (see fig. 4), with the most extensive sampling from the Ash Grove quarry exposures and drillcore in the lower Platte River valley of Nebraska (fig. 1; see Witzke et al., 1996a; Joeckel et al., 2005). Unit 1 has produced abundant and diverse palyno-assemblages (table 1) from a series of samples taken from the lower Dakota outcrop belt of eastern Nebraska (Cass, Sarpy, Jefferson counties) and central Iowa (Guthrie County), and from cores in central and western Kan- 
sas (Lincoln, Stanton counties). These samples include Dakota strata variously referred to the Nishnabotna Member, lower Terra Cotta Member, and Longford Member. This palynostratigraphic unit was first defined by Witzke, Ravn, et al. (1996) and Witzke, Ludvigson, Ravn, et al. (1996), but some additions and modifications are included here. Unit 1 is characterized by occurrences of palyno-taxa not known to range above the early Late Albian Kiowa-Skull Creek depositional cycle elsewhere in the Western Interior of North America including Eucommiidites minor, Disaltriangulisporites irregularis, Foveosporites labiosus, Couperisporites complexus, Interulobites exuperans, and Stoverisporites lunaris. Witzke, Ravn, et al. (1996, p. 17) included D. perplexus and possibly Cicatricosisporites goniodontos and C.patapscoensis on this list, but these species are now known to range into Unit 2 (but are still considered to be Albian indicators). In addition, numerous other Albian indicators are present in Unit 1 (forms not known to range into the Cenomanian) including Densoisporites velatus, Staplinisporites caminus, Cicatricosisporites potomacensis, Disaltriangulisporites mutabilis, D. perplexus, and others (see underlined species on table 1). Witzke, Ravn, et al. (1996) considered Impardecispora marylandensis to be an Albian indicator, but this species is now known to range into the Cenomanian (units 3,4).

Unit 2. Dakota Palynostratigraphic Unit 2 directly corresponds to Dakota Sequence $D_{1}$ of Brenner et al. (2000), which encompasses the middle strata of the Dakota Formation. This stratigraphic interval has been variously assigned to the lower Woodbury and upper Terra Cotta Members and locally includes strata assigned to the upper Nishnabotna Member in Iowa. Unit 2 has produced abundant and diverse palyno-assemblages (table 2) from samples taken in the Dakota outcrop belt of eastern Nebraska (Jefferson, Lancaster, Burt counties), and cores from western Iowa (Woodbury County) and Kansas (Lincoln, Stanton counties). The most extensive sampling was undertaken in brick pit and exploration core sections in the Yankee Hill area of Lancaster County, Nebraska; the Missouri River bluff exposures in Burt County, Nebraska; and brick-pit exploration cores at Sargeant Bluff, Woodbury County, Iowa (fig. 5; also see White et al., 2005). Palynostratigraphic Unit 2 is characterized by the highest occurrences of typical Albian palynomorphs, including Cicatricosisporites apicanalis, C.goniodontos, $C$. patapscoensis, C. potomacensis, Disaltriangulisporites mutabilis, D. perplexus, Impardecispora apiverrucata, I. excavata, Januasporites spiniferus, Plicatella jansonii, Punctatisporites couperi, Scopusporis lautus, Cedripites canadensis, Eucomiidites troedssonii, Podocarpidites multesimus, Quadricolpites reticulatus, and others (see underlined species on table 2). No Cenomanian indicators are known to occur in the unit. It is presently uncertain if any of the contained species are biostratigrapically unique to Unit 2 in the Western Interior, but many last occurrences of Albian species are recorded within the unit. Unit 2 is a relatively coarse biostratigraphic interval defined by the last occurrrences of Albian species above Unit 1 .

Proposed Muddy-Mowry Cycle. The Unit 2 palynoflora shares much in common with that of the upper Albian Muddy Sandstone

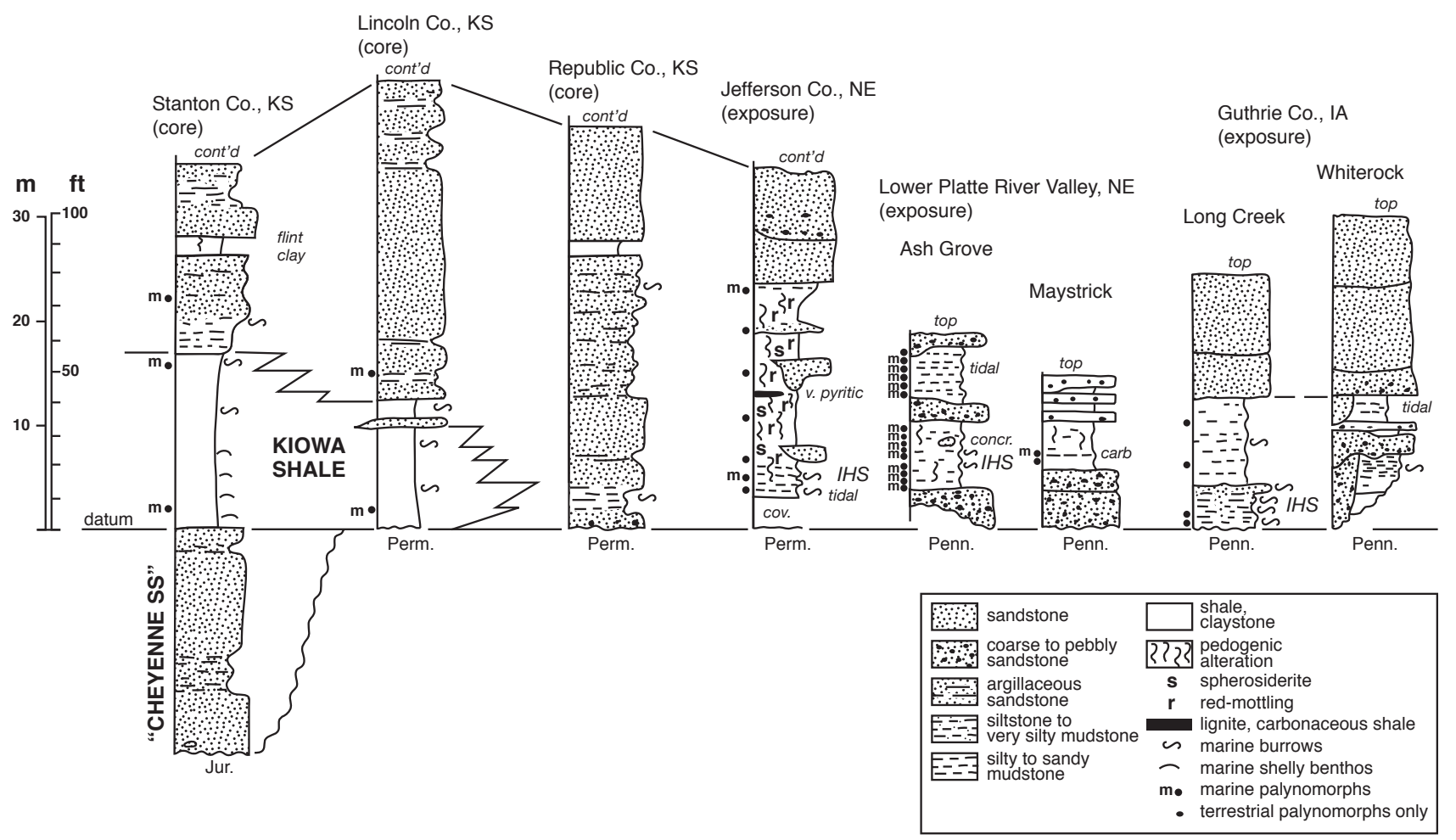

FIGURE 4-Representative stratigraphic sections, lower Dakota Formation, Sequence $\mathrm{D}_{0}$, Kiowa-Skull Creek marine cycle, Iowa, Nebraska, and Kansas ( Palynostratigraphic Unit 1). Positions of palynostratigraphic samples are noted. Dakota strata are replaced westward in Kansas by marine-shale facies of the Kiowa Formation. The location of the KGS Stanton County core along the Kansas-Colorado border is given in Macfarlane et al. (1993, p. 10-11), while locations for the KGS Jones \#1 core; the KGS Kenyon core in Republic County, Kansas; the Jefferson County, Nebraska, study area; the lower Platte River valley study area in eastern Nebraska; and the Guthrie County study area in western Iowa are all shown in fig. 1. Symbol for leaf fossils as in fig. 5. Abbreviations: $\mathrm{m}$ - marine palynomorphs; IHS - inclined heterolithic strata, carb carbonaceous, concr - concretion, Jur - Jurassic, Perm - Permian, Penn - Pennsylvanian, cont'd - continued above. 




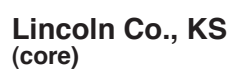

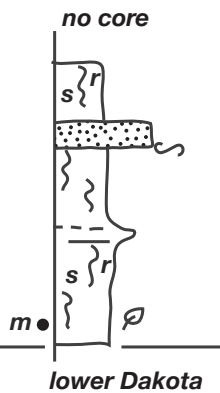



Burt Co., NE (exposure, wells) cont'd (core)

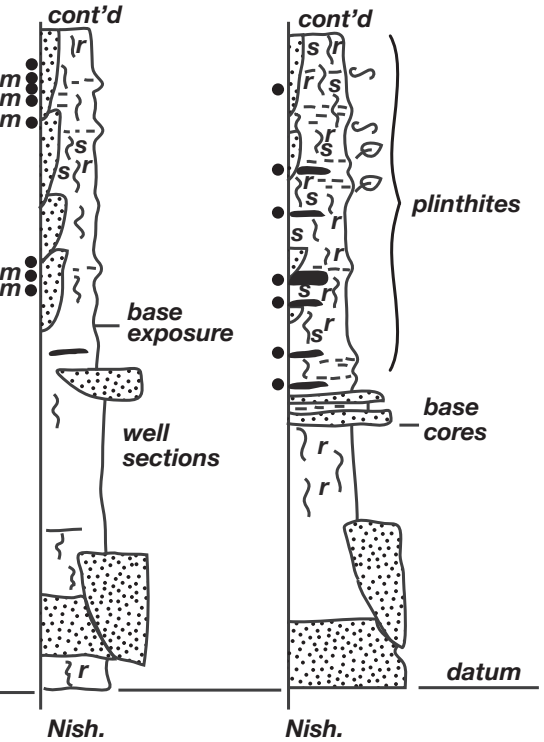

$\varnothing$ leaf fossils

$\backsim$ burrows, marine and nonmarine

FIGURE 5-Representative stratigraphic sections, middle Dakota Formation, Sequence $\mathrm{D}_{1}$, Muddy-Mowry marine cycle, Iowa, Nebraska, and Kansas ( Palynostratigraphic Unit 2). The location of the KGS Stanton County core is given by Macfarlane et al. (1993, p. 10-11), while locations for the KGS Jones \#1 core in Lincoln County, Kansas; the Jefferson County, Nebraska, study area; the Yankee Hill study area in Lancaster County, Nebraska; the Burt County, Nebraska, study area; and portions of the type Dakota area in Woodbury County, Iowa, are shown in fig. 1. Symbols as in fig. 4. Abbreviations: Dak - Dakota Formation; Nish - Nishnabotna Member.

of Wyoming (Ravn, 1995). The Muddy Sandstone interval and equivalent strata in the central Western Interior basin are marked by widespread progradation of sandstone and nonmarine facies, which interstratify with several pulses of marine transgression (e.g. Holbrook et al., 2002, 2006). The base of the Muddy Sandstone and equivalent strata across the Western Interior is recognized to mark a regional unconformity and sequence boundary (SB3) across the basin, from Canada to New Mexico, from Kansas to Montana (e.g., Scott et al., 1998; Scott et al., 2001; Scott et al., 2004; Oboh-Ikuenobe et al., 2007). The Muddy Sandstone is overlain by siliceous marine shale and siltstone strata of the Mowry Shale in the central Western Interior, and the contact between the two is considered to be comformable (ObohIkuenobe et al., 2007). The "Huntsman Shale," which lies above the Muddy/'J' sandstone may represent an eastern tongue of the Mowry Shale in eastern Colorado and adjoining areas of Nebraska and Kansas (Hamilton, 1994; Graham, 2000). The MuddyMowry sequence is capped by a widespread sequence boundary (SB4) across the Western Interior (e.g., Scott et al., 2004). Collectively, the Muddy-Mowry interval and correlative strata are now identified as a discrete and widely recognized multi-phased stratigraphic sequence across the Western Interior basin. Internally, this sequence is marked by complex smaller-scale cyclicity and additional higher-order sequences (e.g., SB3.2) (e.g., Holbrook et al., 2006; Scott et al., 2004; Graham, 2000).

Although the Mowry had been considered to be a lower Cenomanian unit in some previous reports, recent biostratigraphic and chronostratigraphic studies now support an uppermost Albian age (Oboh-Ikuenobe et al., 2007). As such, Dakota Palynostratigraphic Unit 2 apparently can be correlated directly with the Muddy-Mowry interval farther to the west in the central
Western Interior. Like the Muddy-Mowry interval, the correlative middle Dakota succession that includes Unit 2 in Iowa, Kansas, and Nebraska has also been recognized as a discrete sequence, which is separated from overlying Cenomanian strata of the upper Dakota by an erosional surface marked by channeling and widespread soil development (e.g., Hamilton, 1994; Scott et al., 1998; Witzke et al., 1999; Brenner et al., 2000; Gröcke et al., 2006; Witzke, 2007). Even though widespread sequence boundaries constrain the Muddy-Mowry and middle Dakota interval in the Western Interior, most previous studies have variably included this interval within either an expansive Greenhorn or KiowaSkull Creek marine cycle. It was most recently included with the Kiowa-Skull Creek cycle by Scott et al. (2004). In keeping with recent sequence stratigraphic studies of the Dakota Formation and other mid-Cretaceous strata of the Western Interior, it seems desirable to separate this stratigraphic interval from the underlying Kiowa-Skull Creek cycle as well as from the overlying Cenomanian transgressive phases of the lower Greenhorn marine cycle. Therefore, upper Albian strata coeval with Palynostratigraphic Unit 2 are considered to relate to a separate multi-phased marine depositional cycle in the Western Interior here termed the "Muddy-Mowry cycle." Further evidence for marine-influenced deposition in middle Dakota strata coincident with this cycle is presented later in this report.

Unit 3. Dakota Palynostratigraphic Unit 3 corresponds to the basal portion of upper Dakota stratigraphic sequence $\mathrm{D}_{2}$ of Brenner et al. (2000). Unit 3 includes strata of the upper Woodbury Member in Iowa and eastern Nebraska and the Janssen Member of Kansas, and it locally includes facies assigned to the 
upper Terra Cotta Member in areas of Nebraska and Kansas. Unit 3 has been most extensively sampled for palynomorphs in cores from Sioux and Woodbury counties, Iowa, and from exposures in eastern Nebraska (Thurston, Jefferson counties); Kansas cores have not been sampled extensively (fig. 6). Compared to the other three Dakota palynostratigraphic units, the recovered palynoflora of Unit 3 is slightly less diverse (table 3 ). This seeming change in diversity is probably an artifact of sampling and preservation, and likely does not represent an actual decline in floral diversity in the Dakota environments. A number of characteristic Cenomanian species make their first appearance at or near the base of the unit, including Lycopodiacidites arcuatus, Dictyophyllidites impensus, Foveosporites cenomanianus, Foveogleicheniidites confossus, Rugubivesiculites convolutus, and Artiopollis indivisus. Several additional species were regarded as Cenomanian indicators by Witzke et al. (1996a, p. 18), but these are now known to range downward into Unit 2 (Balmeisporites glenelgensis, Petalosporites quadrangulus, Triporoletes pluricellulus). Witzke et al. (1996b) defined the top of Unit 3 at the last-appearance datum of Neoraistrickia robusta (see also Ravn and Witzke, 1995). This interval (below the top of $N$. robusta) was correlated with the lower Cenomanian by Ravn and Witzke (1995). Not previously recognized, a number of additional species (table 3, underlined taxa) also make their last appearance within Unit 3, including Triporoletes simplex, Baculatisporites comaumensis, Cicatricosisporites mediostriatus, Impardecispora trioreticulosa, Ischyosporites disjunctus, Januasporites spiniferus, and Lobatia involucrata.
Unit 4. Dakota Palynostratigraphic Unit 4 is known primarily from a series of lignite samples in uppermost Dakota strata (both core and outcrop sections) from northwestern Iowa (Woodbury, Sioux counties; summarized in Ravn and Witzke, 1995). Additional samples from eastern Nebraska (Thurston, Jefferson counties) and north-central Kansas (Republic, Lincoln counties) are now included within Unit 4. All samples were derived from strata of the upper Woodbury Member in Iowa and Nebraska, and the Janssen Member in Kansas. Cores from farther west in Kansas (Greeley, Stanton counties) show correlative strata to be entirely within marine shale facies of the Graneros Shale (fig. 6). The position of Unit 4 below upper Cenomanian marine strata in Iowa and Nebraska, and the probable lateral equivalency of Unit 4 with middle Cenomanian marine strata in western Kansas, support the correlation of Unit 4 with the middle Cenomanian (see also Ravn and Witzke, 1995).

A few spore species make their first appearance in Unit 4 (table 4), including Cicatricosisporites crassiterminatus and $C$. paradorogensis. The angiosperms show a marked increase in diversity over earlier assemblages, and a number of angiosperm pollen species, including morphologically complex forms, make their first appearance within Unit 4, including Doyleipollenites robbinsiae, Ephedripites ambiguus, Foverotricolporites rhombohedralis, Liliacidites dividuus, Montiapollis hallii, and Tricolpites patens. Witzke, Ravn, et al. (1996) indicated that Foveogleicheniidites confossus and Dictyophyllidites impensus also make their first appearance with Unit 4, but these two species apparently

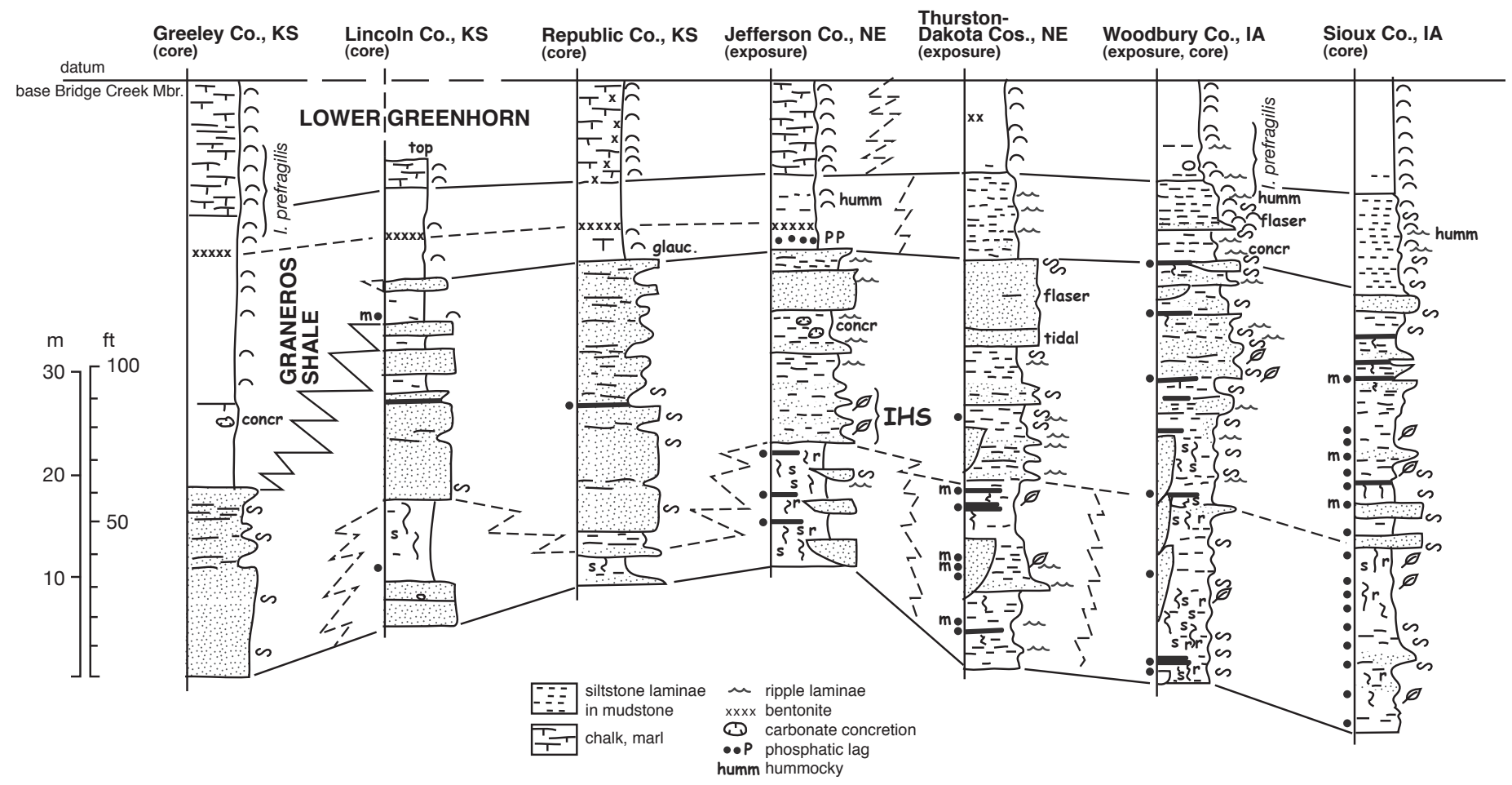

FIGURE 6-Representative stratigraphic sections, upper Dakota Formation, Sequence $\mathrm{D}_{2}$, lower Greenhorn marine cycle, Iowa, Nebraska, and Kansas ( Palynostratigraphic Units 3 and 4). The location for the Amoco No. 1 Bounds core along the Kansas-Colorado border in Greeley County, Kansas, is given by Scott et al. (1998), while the locations of the KGS Jones \#1 core in Lincoln County, Kansas; the KGS Kenyon core in Republic County, Kansas; the Jefferson County, Nebraska, study area; portions of the type Dakota area in Thurston and Dakota counties, Nebraska; and Woodbury County, Iowa, are shown in fig. 1. The IGS Hawarden core in Sioux County, Iowa, is given by Witzke and Ludvigson (1994). Symbols as in figs. 4 and 5. Abbreviations: humm - hummocky, I. prefragilis - Inoceramus prefragilis. 
range downward into upper Unit 3. The first-appearance datums of $M$. hallii and $C$. crassiterminatus have been used to subdivide unit 4 (Witzke, Ravn, et al., 1996; Ravn and Witzke, 1995). Unit 4 also shows a general upward loss of a number of species common in older Albian and lower Cenomanian assemblages (e.g., Nicholsipollis mimas, Cycadopites fragilis, Cicatricosisporites mediostriatus, Impardescispora trioreticulosa, Cingulatriletes congruens, etc.). Strata of Unit 4 show the highest proportion of marine-influenced sedimentary facies (coastal, estuarine) within the Dakota Formation. The increased diversity of angiosperm taxa seen within this unit may suggest that coastal settings may have provided particularly favorable habitats for angiosperm diversification.

\section{Marine Palynomorphs}

Marine palynomorphs (dinoflagellate cysts, acritarchs) are locally associated with assemblages of nonmarine palynomorphs at various stratigraphic positions within the Dakota Formation of Iowa, Nebraska, and Kansas. The initial discovery of Dakota marine palynomorphs was limited to uppermost Dakota strata (Unit 4; see Ravn and Witzke, 1995), primarily in places where Dakota strata interfinger with marginal-marine shale and siltstone units of the lower Greenhorn marine cycle. The subsequent discovery of common marine palynomorphs in basal Dakota strata (Unit 1) of the lower Platte Valley in eastern Nebraska (fig. 4, table 5) indicated that marine-influenced sedimentation also characterized other portions of the Dakota succession, including strata equivalent to the maximum transgressive phases of the Kiowa-Skull Creek marine cycle (Witzke, Ravn, et al., 1996; Witzke et al., 1999). Although Witzke, Ravn, et al. (1996) indicated that marine palynomorphs were absent from palynostratigraphic units 2 and 3, subsequent samples from eastern Nebraska (Lancaster, Burt, Thurston counties) revealed that marine palynomophs occur at a number of stratigraphic positions within units 2 and 3 as well (as first reported by Witzke et al., 1999). These occurrences provide indisputable evidence for recurring episodes of localized marine influence during Dakota deposition, most likely associated with estuaries that encroached eastward at times of relative sea-level rise in the Western Interior seaway (see subsequent discussions).

None of the recovered dinoflagellate cysts and acritarchs from the Dakota Formation apparently is of any particular biostratigraphic utility. Nevertheless, the occurrences of marine palynomorphs in the Dakota Formation (tables 5-7) likely can be used to characterize various estuarine and brackish-water biofacies associations. Certain acritarch genera occur in many of the Dakota marine palynomorph assemblages, especially Cymatiosphaera, Dictyotidium, Micrhystridium, Veryhachium,

TABLE 5-Late Albian marine palynomorphs; Kiowa-Skull Creek depositional cycle; basal Dakota Formation and equivalent strata, eastern estuarine and shallow-marine facies. p - Platte River valley, eastern Nebraska; j - Jefferson County, Nebraska (eastern estuarine facies of basal Dakota Formation); k - Kansas cores (Kiowa Formation, basal Dakota Formation); m - western Manitoba-eastern Saskatchewan cores and exposures (upper Swan River Formation, Skull Creek Member of lower Ashville Formation, Pense Formation); identifications by Robert L. Ravn. Taxa from lower Dakota Formation of Kansas-Nebraska shown in bold.

\begin{tabular}{|c|c|c|c|}
\hline Achomosphaera? sp. & $\mathrm{k}$ & indet. leiosphere spp. & $\mathrm{p}$ \\
\hline Alterbidinium? sp. & $\mathrm{m}$ & Litosphaeridium arundum & $\mathrm{m}$ \\
\hline Apteodinium sp. & $\mathrm{k}$ & cf. Lophosphaeridium sp. & $\mathrm{p}$ \\
\hline Ascodinium sp. & $\mathrm{k}$ & Michystridium spp. & $\mathrm{k}, \mathrm{m}, \mathrm{p}$ \\
\hline Baltioladinium jaegeri & $\mathrm{m}$ & Odontochitina operculata & $\mathrm{k}, \mathrm{m}$ \\
\hline Baltisphaeridium sp. & $\mathrm{p}, \mathrm{j}$ & O. rhakodes & $\mathrm{k}$ \\
\hline Callaiosphaeridium? sp. & $\mathrm{m}$ & Oligosphaeridium albertense & $\mathrm{m}$ \\
\hline Circulodinium distinctum & $\mathrm{k}$ & O. complex & $\mathrm{k}, \mathrm{m}$ \\
\hline C. sp. & $\mathrm{m}$ & O.pulcherrimum & $\mathrm{k}$ \\
\hline Chlamydophorella sp. cf. C. discreta & $\mathrm{k}$ & O. totum & $\mathrm{m}$ \\
\hline C. nyei & $\mathrm{m}$ & Ovoidinium verrucosum & $\mathrm{m}$ \\
\hline C?. sp. & $\mathrm{k}$ & Palaeoperidinium cretaceum & $\mathrm{k}, \mathrm{m}$ \\
\hline Cometodinium sp. cf. C. whitei & $\mathrm{p}, \mathrm{j}$ & Pseudoceratium interiorense & $\mathrm{m}$ \\
\hline C.? sp. & $\mathrm{m}$ & P.polymorphum & $\mathrm{m}$ \\
\hline Coronifera oceanica & $\mathrm{k}$ & Pterodinium sp. cf. P. aliferum & $\mathrm{m}$ \\
\hline Crassosphaera sp. & $\mathrm{m}$ & P. sp. & $\mathrm{m}$ \\
\hline Cribroperidinium edwardsii & $\mathrm{m}$ & Pterospermella sp. cf. $P$. hartii & $\mathrm{k}$ \\
\hline C. spp. & $\mathrm{k}, \mathrm{m}$ & $P$. sp. & $\mathrm{k}, \mathrm{m}$ \\
\hline Cyclonephelium sp. cf. C. compactum & $\mathrm{k}, \mathrm{m}$ & Senoniasphaera sp. & $\mathrm{k}$ \\
\hline Cymatiosphaera sp. & $\mathrm{m}$ & indet. skolochorate dinocyst & $\mathrm{p}, \mathrm{j}$ \\
\hline cf. Dinopterygium cladoides & $\mathrm{k}$ & Spinidinium sp. & $\mathrm{m}$ \\
\hline Exochosphaeridium? sp. & $\mathrm{k}$ & Spiniferites ramosus & $\mathrm{m}$ \\
\hline Fromea amphora & $\mathrm{m}$ & S. sp. & $\mathrm{k}, \mathrm{m}$ \\
\hline F. fragilis & $\mathrm{m}$ & Striphrosphaeridium anthophorum & $\mathrm{m}$ \\
\hline indet. gonyaulacoid dinocyst & $\mathrm{p}$ & Subtilisphaera sp. & $\mathrm{k}$ \\
\hline Heterosphaeridium difficile & $\mathrm{k}$ & ?Systematophora sp. & $\mathrm{k}, \mathrm{p}$ \\
\hline Hystrichodinium pulchrum & $\mathrm{k}, \mathrm{p}$ & ?Trichodinium $\mathrm{sp}$. & $\mathrm{k}$ \\
\hline Impletosphaderidium spp. & $\mathrm{k}, \mathrm{m}, \mathrm{p}, \mathrm{j}$ & Veryhachium sp. & $k, m, p, j$ \\
\hline Kiokansium williamsii & $\mathrm{m}$ & Xiphophoridium alatum & $\mathrm{k}$ \\
\hline$K . \mathrm{sp}$. & $\mathrm{k}$ & indet. angular dinocyst & $\mathrm{p}$ \\
\hline Leiosphaeridia sp. & $\mathrm{p}$ & indet. alate spinose dinocyst & $\mathrm{p}$ \\
\hline
\end{tabular}


TABLE 6-Latest Albian marine palynomorphs, Muddy-Mowry depositional cycle, middle Dakota Formation, eastern estuarine facies. $\mathrm{n}$ - eastern Nebraska, $\mathrm{k}$ - central Kansas; identifications by Robert L. Ravn.

\begin{tabular}{ll}
\hline \hline Cribroperidinium $\mathrm{sp}$. & $\mathrm{k}$ \\
Cymatiosphaera $\mathrm{sp}$. & $\mathrm{n}$ \\
cf. Dinopterygium cladoides & $\mathrm{k}$ \\
Dictyotidium $\mathrm{sp}$. & $\mathrm{n}$ \\
cf. Gorgonisphaeridium $\mathrm{sp}$. & $\mathrm{n}$ \\
Hystrichodinium cf. pulchrum & $\mathrm{n}$ \\
Impletosphaeridium? sp. & $\mathrm{k}, \mathrm{n}$ \\
Leiosphaeridia sp. & $\mathrm{n}$ \\
Micrhystridium spp. & $\mathrm{n}$ \\
Odontochitina operculata & $\mathrm{n}$ \\
indet. ?pilomate cyst & $\mathrm{n}$ \\
indet. skolochorate dinocyst & $\mathrm{n}$ \\
Veryhachium spp. & $\mathrm{k}, \mathrm{n}$ \\
\hline
\end{tabular}

Baltisphaeridium, and Leiosphaeridia. Several genera of dinoflagellate cysts commonly co-occur within many of these marineinfluenced Dakota assemblages, including Cribroperidinium, Hystrichodinium, Impletosphaeridium, Odontochitina, Fromea, Cyclonephelium, and indeterminate skolochorate dinocysts. Some dinoflagellate cysts may be restricted to particular Dakota palynostratigraphic units, possibly including Cometodinium (Unit 1), Cleistosphaeridium (Unit 4), and Oligosphaeridium (Unit 4).

Low-diversity Albian-Cenomanian marine-influenced palynomorph associations described by Oboh-Ikuenobe et al. $(2004,2007)$ from the Western Interior include dinoflagellate cysts (Cyclonephelium, Palaeoperidinium, Cribroperidinium) and acritarchs (Pterospermella). They interpreted these assemblages to represent nearshore and probably brackish-water biofacies. Of
TABLE 7-Cenomanian marine palynomorphs, lower Greenhorn depositional cycle, upper Dakota Formation, eastern estuarine facies western Iowa, eastern Nebraska, central Kansas; identifications by Robert L. Ravn.

\begin{tabular}{l}
\hline \hline Baltisphaeridium $\mathrm{sp}$. \\
Circulodinium distinctum \\
Cleistosphaeridium $\mathrm{sp}$. \\
Criboperidinium? sp. \\
Cyclonephelium $\mathrm{sp}$. \\
Dictyotidium? sp. \\
Fromea? sp. \\
Impletosphaeridium $\mathrm{sp}$. \\
indet. leiosphere sp. \\
Micrhystridium $\mathrm{sp}$. \\
Multiplicisphaeridium $\mathrm{sp}$. \\
Odontochitina costata \\
Oligosphaeridium $\mathrm{sp}$. \\
indet. skolochorate dinocyst \\
Trichodinium $\mathrm{sp}$. \\
Veryhachium $\mathrm{spp}$. \\
\hline
\end{tabular}

note, Cyclonephelium, Palaeoperidinium, and Pterospermella have not been recovered in Dakota strata of Iowa or eastern Nebraska, but these taxa have been found in more seaward areas of western Kansas and Manitoba, where nonmarine Dakota-Swan River facies interfinger with marine shale facies of the Kiowa, Skull Creek, and Graneros formations (tables 5, 7). This supports a shallow-marine to nearshore habitat for these forms, but these taxa apparently were not associated with the large estuarine systems that pushed eastward into the Dakota coastal plain during times of regional marine transgression. The above-noted dinoflagellate-acritarch associations from the Dakota Formation of Iowa and Nebraska are interpreted to represent biofacies associated with the eastern estuaries, and all of these taxa were likely brackish-water tolerant to varying degrees.

\section{Evidence for Marine-influenced Sedimentation in the Dakota Formation}

Since the earliest studies of the Dakota Formation in the type area of Iowa and Nebraska, the formation has been considered to be mostly, if not entirely, of fluvial origin. It is true that the Dakota Formation is dominated by fluvial and flood-basin depositional facies, commonly overprinted by pedogenic alteration. However, evidence for marine-influenced depositional facies in upper Dakota strata was presented by Witzke et al. (1983) and Witzke and Ludvigson (1994), who interpreted deltaic, nearshore-mud, and coastal-swamp environments associated with transgression of the Greenhorn seaway across the eastern coastal plain during the middle Cenomanian. However, evidence for older Albian and early Cenomanian marine influence in the Dakota type area was not recognized in those reports.

The discovery of marine palynomorphs and tidal rhythmites in lower Dakota strata (Albian) of eastern Nebraska (Witzke et al., 1996c; Brenner et al., 2000) significantly changed our understanding of Dakota sedimentation in the region. The resulting paradigm shift recognized the possibility that marine-influenced deposition, particularly that associated with brackish-water estuaries, was part of the regional depositional mosaic of Dakota sedimentation (Witzke, Ludvigson, Brenner, et al., 1996, p. 11).
Further studies have supported this new perspective on Dakota deposition, recognizing marine influence at multiple stratigraphic positions within the Dakota succession at positions far inland from the Western Interior seaway's eastern shoreline (Witzke et al., 1999; Brenner et al., 2000, 2003; Joeckel et al., 2005; Gröcke et al., 2006). This paradigm shift has necessitated changes in interpretations of coastal geographies along the eastern margin of the seaway. Influenced by descriptions of Cretaceous deltaic systems along the western margin of the seaway, earlier Dakota depositional models portrayed constructional deltas advancing seaward from the eastern margin (e.g., Witzke and Ludvigson, 1994). The subsequent recognition of large estuarine systems in the Dakota depositional mosaic now seems to better constrain a broadly embayed coastline, not one dominated by constructional deltas (in other words, an "innie" vs "outie" eastern coastline; Ludvigson, Witzke, et al., 1998).

\section{Paleontologic Lines of Evidence}

Several kinds of paleontologic information provide definitive evidence for marine influence during Dakota deposition. As 
discussed earlier, the presence of marine palynomorphs, including acritarchs and dinoflagellate cysts, provides compelling confirmation that not all of the Dakota Formation was deposited in nonmarine environments. Many of the recovered acritarchs and dinocysts comprise biofacies that most likely represent brackish-water associations, as these do not typically occur with invertebrate fossils or foraminfera that are considered to inhabit open-marine environments (normal marine salinity). Trace-fossil assemblages have been recognized within all three major stratigraphic sequences of the Dakota Formation, and these include burrow forms that generally are considered to be marine- or brackish-water indicators, including Skolithos and thalassinoid networks. Some particularly well developed trace-fossil assemblages have been recognized in basal Dakota strata of Jefferson County, Nebraska, and Guthrie County, Iowa (see Brenner et al., 2003, p. 445-446), but the characterization of ichnotaxa and their environmental interpretation awaits further study. Small horizontal burrows have been recognized in silt laminae and silt interbeds associated with tidally modulated units within all three sequences in the formation. Upper Dakota units with evidence of marine influence are noted to contain a variety of horizontal, subvertical, vertical, and 'u'-shaped burrows (Witzke and Ludvigson, 1987).

Although invertebrate fossils generally are not common in the Dakota Formation, some mollusk fossils also provide compelling evidence for marine influence. Some siltstone and sandstone beds in the upper Woodbury Member in the uppermost part of the formation in northwestern Iowa and northeastern Nebraska locally contain molds of high-spired gastropods and marine bivalves, including veneroids, arcoids, nuculoids, ostreids, and inoceramids (Witzke and Ludvigson, 1987, 1994; Tester, 1931). Hattin (1967) described a relatively diverse molluscan association from the upper Janssen Clay Member in the upper Dakota sandstone beds in central Kansas, including oysters (Crassostrea, Exogyra), mytilaceans (Brachidontes, Modiolus), and a variety of other bivalve genera (Breviarca, Corbula?, Parmicorbula, Anatimya, Cymbophora, Geltena, Isocardia, Laternula, Linearia, Lucina, Yoldia?). He interpreted these faunas to be shallow-water brackish to marine assemblages. Some of the brackish faunas are intermixed locally with freshwater forms (unionids). Brackish to marine mollusk fossils, including Crassostrea, also have been noted in lower Dakota strata of Nebraska and Kansas (Franks, 1975, 1979; Witzke et al., 1983). The occurrence of Brachidontes within leaf-rich carbonaceous mudstones in uppermost Albian strata of Jefferson County, Nebraska (Upchurch and Dilcher, 1990), is particularly noteworthy, as this is the only known occurrence of brackish-water mollusks in middle Dakota strata of the region (our revised palynostratigraphy places these strata within the Albian Muddy cycle, and not within the Cenomanian as originally reported). This occurrence is even more surprising considering that extensive palynological sampling of this unit failed to produce any associated acritarchs or dinocysts. Although brackish to marine mollusk assemblages are not commonly encountered in the Dakota Formation, when identified they provide compelling evidence for marine-influenced deposition (i.e., saltwater environments).

Some marine-influenced mudstone units in the upper Dakota Formation contain low-diversity assemblages of agglutinated foraminifera, although sampling has been sparse and preliminary.
Such assemblages are interpreted to live in nearshore, estuarine, and coastal marsh environments. Tibert and Leckie (2004) interpreted the occurrence of agglutinated foraminifera in coal-bearing Turonian strata along the western margin of the Western Interior seaway as evidence for high-frequency estuarine sea-level cycles. van Hengstum et al. (2007) recently reported on the occurrence of agglutinated foraminifera from carbonaceous shale leaf beds in the Yankee Hill claypits in Lancaster County, Nebraska, from strata included in Palynostratigraphic Unit 2. While they interpreted the enclosing strata as lacustrine in origin, the occurrence of marine palynomorphs in carbonaceous shales from this locale (fig. 2, table 6), and the interpreted tidal modulation of carbonaceous shaly rhythmites at this locale (see next section) may suggest that the agglutinated foraminifera inhabited brackish estuarine environments.

Further study needs to be undertaken, but it seems likely that such assemblages will be recovered in other parts of the Dakota succession, as well. Some sandstone and siltstone lenses in the uppermost Dakota Formation of Iowa and Nebraska locally contain concentrations of marine-vertebrate fossils, primarily shark teeth and teleost scales, bones, and teeth (including ichthyodectids).

\section{Sedimentologic Lines of Evidence}

Numerous sedimentary structures in the Dakota Formation commonly are associated with marine to brackish paleontologic indicators, and many of these are suggestive of, although not necessarily definitive for, marine-influenced sedimentation. These sedimentary structures provide supporting evidence for sedimentary processes associated with estuarine, deltaic, and coastal environments (Witzke and Ludvigson, 1994). A variety of silt-sand sedimentary bedforms in upper Dakota strata are most consistent with marine-influenced deposition in shallow nearshore to outer estuarine settings, especially hummocky and flaser bedding, but also including silt-sand laminae, symmetrical starved ripples, and low-angle cross stratification (Witzke and Ludvigson, 1987, 1994). Such structures may result from storm currents and tidal flow. Compelling evidence of marine influence is seen where Dakota sandstone and siltstone beds interfinger with marine shale facies of the Kiowa and Graneros shales. Some nearshore-marine Dakota sandstones locally are glauconitic (or chloritic). Some marine-influenced Dakota mudstones locally contain carbonate concretions (commonly septarian).

Inclined heterolithic strata (IHS) are identified at multiple stratigraphic positions within the Dakota succession, including 1) lower Dakota units in Cass and Jefferson counties, Nebraska (fig. 4), and Guthrie County, Iowa; 2) middle Dakota units in Lancaster and Jefferson counties, Nebraska; and 3) and upper Dakota units in Woodbury County, Iowa, and Thurston and Jefferson counties, Nebraska (fig. 6). These IHS units show laterally accreted sets of dipping sandstone, siltstone, and mudstone (commonly carbonaceous), and some contain leaf compressions and carbonized logs. Many IHS units are pyritic, some contain marine burrows, some have produced marine palynomorphs, and some contain tidal rhythmites. The bulk of the Dakota IHS units are considered to have formed by lateral accretion within inner estuarine and bayhead settings, and many appear to have been 
tidally influenced. Lockley et al. (2006) illustrated IHS units from the Middle Mesa Rica Sandstone Member of the Dakota Group along the Colorado-Kansas border, from strata included in the "Muddy cycle." Mud-draped crossbedded sandstone bodies are seen in some marine-influenced facies that likely record alternations between high- and low-energy flow regimes within fluvialestuarine settings (Brenner et al., 2000, p. 874).

Tidal rhythmites are strata that display distinctive bundles of thickening-and-thinning laminae, typically organized into groups of 14 and 28 laminae that are interpreted to record neap-spring tidal cycles (see Brenner et al., 2000, p. 873). Such rhythmic laminae are identified in the Dakota Formation within several lithologies: 1) foreset laminae within crossbedded sandstones (e.g., Witzke and Ludvigson, 1994, p. 49), 2) laminated siltstones, and 3) silt/sand-laminated mudstones (Brenner et al., 2000, p. 873). Tidal rhythmites commonly are associated with IHS units and with other laterally accreted cross strata in the Dakota Formation. Such occurrences are interpreted to relate to deposition in tidal estuaries, most of which represent fills within incised channels. Tidal rhythmites are now identified within all three sequences of the Dakota succession at localities in Iowa and Nebraska. The best examples are from basal Dakota strata of the Kiowa-Skull Creek marine cycle at the Ash Grove pit in Cass County, Nebraska, where analysis of the tidal bundling indicated mesotidal ranges (Zawistowski et al., 1996; see also Brenner et al., 2000, 2003; Joeckel et al., 2005). Tidally modulated laminites also are known from the same general stratigraphic position in Jefferson County, Nebraska, and Guthrie County, Iowa (fig. 4). The recognition of tidal rhythmites in middle Dakota strata (Muddy cycle) of Jefferson and Lancaster counties, Nebraska (Korus, 2000), is particularly noteworthy because the latest Albian has previously been considered to be a time of major seaway withdrawal across much of the Western Interior.

Much of the Dakota Formation has sparse to absent sedimentary iron sulfides (pyrite), but other iron minerals, especially siderite and iron oxides, are common in some beds. However, pyrite is locally abundant at some stratigraphic positions, variously seen as discrete pyrite nodules, disseminated framboids and crystals, and pyrite cements. Pyrite is most commonly recognized in the Dakota Formation within IHS units and associated with carbonaceous shales and lignites. Although pyrite and other iron sulfide deposition is not exclusive to marine or marine-influenced environments, a ready and available supply of dissolved sulfate is needed to produce large quantities of sulfide through anaerobicbacterial sulfate reduction. Because seawater is a readily available source of abundant sulfate in marine-influenced depositional settings, an abundance of sedimentary pyrite in certain strata is strongly supportive of marine influence during deposition (Ward, 2002). White et al. (2000) considered the abundance of pyrite in Albian carbonaceous mudstones and lignites of Ontario to be most easily explained by derivation from brackish estuarine sulfate sources, a reasonable conclusion based on the recognition of other paleontologic and geochemical indicators of marine influence in associated strata.

\section{Geochemical Lines of Evidence}

Geochemical information can provide additional evidence for marine influence during deposition and early diagenesis of
Dakota sediments. Analysis of organic matter in many Dakota mudstones is potentially significant, as the organic geochemistry can reveal compelling evidence for marine or marine-influenced sedimentation (Young, 2002; White et al., 2000). Most Type II organic matter analyzed by Rock Eval pyrolysis (Espitalie et al., 1977) is derived from marine phytoplankton, which contrasts with organic matter derived from terrestrial plants (Type III) and freshwater algae (Type I) (Espitalie et al., 1977). Calculations from Rock Eval pyrolysis yield values for the Hydrogen Index (HI) and Oxygen Index (OI) of the organic matter in a sample, and the relative importance of the three types of organic matter is reflected by these values. Young's (2002) evaluation of organic matter from Dakota Formation cores in Iowa and Kansas showed intervals with mixed terrestrial and marine values, consistent with paleontologic and sedimentologic indicators previously discussed. White et al. (2000) used evidence from organic geochemistry, pyrite distribution, and palynology to demonstrate estuarine influence in coeval Albian strata of Ontario.

Geochemical study of carbonate minerals in the Dakota Formation provide additional lines of evidence for the mixing of meteoric freshwater and marine to brackish ground water in coastal and estuarine phreatic ground-water systems. Early diagenetic synsedimentary calcite cements in siltstone and sandstone beds are noted at certain stratigraphic positions within the Dakota Formation, including a dinosaur track site in Jefferson County, Nebraska (Joeckel et al., 2004; Phillips et al., 2003; Phillips, 2004; Phillips et al., 2007). Detailed stable isotope geochemistry of the carbonate cement paragenetic sequence, as shown by data arrayed along fluid mixing curves in $\delta^{18} \mathrm{O}$ and $\delta^{13} \mathrm{C}$ isotope space, demonstrate that some of the Dakota calcite cements were precipitated in mixed ground-water systems with brackish influence (Phillips et al., 2007). Such investigations demonstrate early diagenetic processes associated with phreatic "subterranean estuary" systems (sensu Moore, 1999), a term that refers to solute transport and mixing in ground-water-flow systems that discharge to submarine environments. Radioisotope measurements along modern coasts have indicated that ground-water flux must be about $40 \%$ of the flux from riverine discharge (Moore, 1996), a far greater proportion than previously realized. Processes related to the existence of subterranean estuaries are recognized in authigenic cements in strata of the Dakota Formation, and certain calcite-cemented horizons likely correspond to fluid-mixing zones beneath marine-flooding surfaces (Phillips et al., 2007; Ufnar et al., 2004a).

The Dakota Formation is replete with well-developed paleosols, and many paleosols show an abundance of small siderite spherulite (iron carbonate) concretions (termed spherosiderite) that precipitated in the ancient wetland soils. Geochemical data recovered from these spherosiderites also have shown marine or brackish influence in the coastal phreatic systems. Siderite that precipitated in freshwater settings is commonly very pure (>95\% $\mathrm{FeCO}_{3}$; Mozley, 1989), whereas marine siderite is impure (incorporating other cations, especially Ca)(White et al., 2005). This relationship led to the recognition of brackish influence on siderite precipitation in middle Dakota strata (Albian Muddy cycle) of Iowa (as also indicated by studies of Ludvigson et al., 1995; Ludvigson et al., 1996, discussed below), with stratigraphic variations likely recording cyclic shifts in the updip migration of brackish ground water along the eastern coastal plain, probably 
reflecting parasequence-scale changes in sea level (Ludvigson et al., 1996).

Chemostratigraphic excursions in $\delta^{18} \mathrm{O}$ recorded by stratigraphic successions of spherosiderite-bearing paleosols may also reflect the mixing of marine and meteoric ground waters (Hart et al., 1992). Ludvigson et al. (1995) and Ludvigson et al. (1996) interpreted mixing-zone spherosiderites from lower Dakota strata of Nebraska and middle Dakota strata of Iowa, which displayed positive covariant trends in $\delta^{18} \mathrm{O}$ and $\delta^{13} \mathrm{C}$. These trends likely resulted from the mixing of meteoric phreatic and modified marine phreatic fluids. Ufnar et al. (2001) interpreted spherosiderites from Albian paleosols in Canada to show evidence of meteoric-marine fluid mixing in an interval with enriched $\delta^{18} \mathrm{O}$ and increased minor element concentrations ( $\mathrm{Mg}$ and $\mathrm{Ca}$ ). By contrast, Phillips (2004, p. 142) identified other early diagenetic siderite and calcite cements from the same stratigraphic interval with yet even more depleted $\delta^{18} \mathrm{O}$ values and increased $\mathrm{Mg}$ and Ca concentrations that he suggested may indicate meteoricmarine mixing. Although further work on siderite geochemistry is needed, it seems clear that evaluation of stable isotopic and minor element chemistry may afford additional means for evaluating marine influence in the Dakota paleoground-water systems.

As noted above, abundant syndepositional pyrite is considered to be a likely sedimentary indicator for marine influence, and pyrite is common in some Dakota facies. However, it should be noted that pyrite and siderite are generally not considered to be coeval mineral phases, because siderite growth is restricted to environments in which sulfide activity is absent. Sulfate availability is likely the limiting factor in the formation of pyrite over siderite (Carpenter et al., 1988), and marine and brackish waters typically contain abundant sulfate unless modified by sulfatereducing bacteria. Any Dakota siderite precipitation that occurred within brackish ground water must have been in phreatic systems with mixing ratios of less than $25 \%$ seawater (see Ufnar et al., 2004a, p. 139), or systems in which sulfate reduction already had either progressed largely if not entirely to completion (White et al., 2005). Microscopic pyrite inclusions at the centers of some Dakota spherosiderites provide evidence of this process (White et al., 2005, p. 15).

\section{Distribution of Marine-influenced Facies in the Dakota Sequences}

Marine-influenced depositional facies are recognized at various stratigraphic positions within all three Dakota sequences $\left(\mathrm{D}_{0}\right.$, $\mathrm{D}_{1}, \mathrm{D}_{2}$ of Brenner et al., 2000) in areas of Iowa, Nebraska, and Kansas. The $\mathrm{D}_{0}$ sequence is coeval with the Kiowa-Skull Creek marine cycle of the Western Interior, and marine-influenced facies are best developed in the lower half of this sequence (fig. 4), apparently recording the eastward expansion of estuarine environments coincident with maximum transgressive expansion of the Kiowa-Skull Creek seaway. Tidal rhythmites, IHS units, marine burrows, pyritic mudstones, and marine palynomorphs are observed in the sequence eastward into eastern Nebraska, as displayed in outcrop in Jefferson and Cass counties. Two or three intervals within the Nebraska sequence locally are marked by marine indicators, separated by paleosols or nonmarine sandstone channels.
The discovery of IHS units, tidal rhythmites, burrowed laminites, pyritic mudstones, and pyrite nodules in lower Dakota strata of Guthrie County, Iowa, is particularly noteworthy (Witzke and Ludvigson, 1998; Phillips and White, 1998). The sedimentary evidence indicates that during the Kiowa-Skull Creek interval, estuaries and tidal influence extended as far as central Iowa, an area that lies $450 \mathrm{~km}$ (280 mi) east of the marine Kiowa shale edge (this shale edge marks the approximate margin of the Western Interior sea at that time).

As noted by Joeckel et al. (2007), a southwest-northeast transect of the Dakota outcrop belt in the midcontinent shows that the transition from Kiowa marine shales to estuarine facies occurs abruptly at Salina, Kansas, and extends to Guthrie County, Iowa, near Des Moines (fig. 1) along a line roughly approximating the Cretaceous paleoslope. The large lateral extent of this paleoestuary was governed by two factors: 1) flooding of low-gradient paleovalleys by sea-level rise during the Kiowa-Skull Creek marine transgression (Brenner et al., 2003); and 2) amplification of tidal ranges in tidally influenced rivers discharging to estuaries. For a recent example, Kvale and Archer (2007) noted that tidal influences extend over $500 \mathrm{~km}$ (310 mi) inland along the Amazon River, the river system with the largest fluvial discharge in the modern world.

Of note, the apparent absence of marine palynomorphs in Guthrie County, Iowa, may suggest deposition in the inner estuary where freshwater influx was highest and salinities lowest. The geographic distribution of marine-influenced and estuarine facies in the lower Dakota succession provides compelling evidence for very large estuaries indeed, among the largest known in the modern or ancient world. The distribution of lower Dakota sedimentary facies supports a paleogeographic interpretation of a Late Albian coastal plain along the eastern margin of the Western Interior sea with deeply embayed estuaries. Such large estuaries apparently developed at times of maximum-marine flooding (maximum sea level) of the Kiowa-Skull Creek sea. During times of falling sea level and shoreline progradation, the estuaries likely were filled by nonmarine fluvial sediments.

As discussed previously, Middle Dakota strata (sequence $D_{1}$ of Brenner et al., 2000) are correlative with the latest Albian Muddy Sandstone and Mowry Shale of Colorado and Wyoming and accordingly are included within the newly recognized "Muddy-Mowry marine cycle" of the Western Interior. Indicators of marine-influenced deposition have been noted in this sequence in western Kansas (Hamilton, 1994; Scott et al., 1998), western Nebraska (Graham, 2000), eastern Nebraska (Witzke et al., 1999; Korus, 2000; Phillips et al., 2007), and Iowa (White et al., 2005). The recent report of agglutinated foraminifera from this interval in eastern Nebraska (van Hengstum et al., 2007) further supports this interpretation. Marine palynomorphs have been identified in several stratigraphic positions in eastern Nebraska (fig. 5), and tidal laminites have also been identified in the lower and middle parts of the sequence in southeastern Nebraska (fig. 5; also Korus, 2000). Oboh-Ikuenobe et al. (2007) have similarly noted the widespread distribution of marine palynomorphs in fluvial-estuarine strata in the Western Interior basin during the interval of the Late Albian "Muddy marine cycle." Holbrook (2001) proposed that the Cucharas Canyon and Huerfano Canyon alloformations in southeastern Colorado are similarly related to the "Muddy marine cycle," while Holbrook et al. (2006) further subdivided 
the interval into even smaller-scale cycles. These units are all included in the newly recognized "Muddy-Mowry marine cycle."

Previously discussed calcite cements from the lower part of this interval in Jefferson County, Nebraska, show geochemical evidence of a marine-influenced phreatic ground-water system; the sandstone bed contains dinosaur footprints and is interpreted to represent a marine-flooding surface (Phillips et al., 2007). Pyritic beds, siderite geochemistry, and burrows suggest marine influence as far east as western Iowa during deposition of upper Muddy-Mowry cycle strata.

Indicators of marine-influenced sedimentation are recognized in Dakota sequence $\mathrm{D}_{1}$ in at least three stratigraphic positions. The lower interval with marine palynomorphs, tidal rhythmites, and burrows is the most widespread and best-developed interval with evidence for marine influence (fig. 5). Middle strata of this sequence contain marine palynomorphs and tidal rhythmites in Lancaster and Burt counties, Nebraska (fig. 5), and upper strata contain indicators of marine influence at localities in Nebraska and Iowa, including marine palynomorphs from as far east as Burt County. Each of these three intervals with evidence for marine-influenced and estuarine deposition is separated from underlying and overlying units by nonmarine strata with paleosols and sandstone channels, suggesting several cyclic expansions and contractions of the interior seaway during sequence $\mathrm{D}_{1}$.

The latest Albian Muddy-Mowry interval generally has been considered to mark a general contraction of the Western Interior seaway northward to Montana and Canada, but the extent of the seaway during that time has remained problematic. Similarly, Mowry marine shales generally have been interpreted to have been deposited in a relatively constricted seaway, cut off to the south across northern Colorado and extending no further east than western Nebraska (Reeside and Cobban, 1960). However, the identification of marine-influenced deposition as far east as eastern Nebraska and western Iowa during portions of the Muddy-Mowry cycle suggests that estuaries extended eastward from an interior seaway that may have been of significantly greater geographic extent than previously recognized (Witzke et al., 1999; Witzke, 2007). Even if immense estuaries extended eastward as far as 400-500 km (248-310 mi) into the Dakota coastal plain, the adjoining seaway must have expanded to at least as far as central Nebraska and western Kansas. Of note, several authors have postulated ephemeral through-going seaway connections in the Western Interior during the latest Albian, joining Boreal and Tethyan realms (Holbrook et al., 2002; Scott et al., 2004; Oboh-Ikuenobe et al., 2004; Oboh-Ikuenobe et al., 2007). It is here suggested that these ephemeral seaway connections expanded even farther eastward into Kansas and Nebraska, but pedogenesis and erosional channeling during sea-level lowstands may have obscured much of the sedimentary evidence for marine deposition in those areas. The isolated preservation of restricted marine and estuarine strata of the Muddy-Mowry interval in local interfluve positions beneath multiple incised sequence boundaries in southeastern Colorado (Holbrook et al., 2006) is illustrative of these phenomena.

Multiple phased transgression of the Greenhorn marine cycle during the early and middle Cenomanian resulted in the progressive eastward incursion of estuarine and marine-influenced deposition that encroached across the Dakota coastal plain. There are multiple stratigraphic levels in upper Dakota strata of Iowa, Ne- braska, and Kansas with evidence for marine-influenced deposition (fig. 6), many of them separated by episodes of pedogenesis and channeling, especially in the lower part. Dakota nonmarine, estuarine, and coastal facies were displaced by open-marine facies of the Graneros and Greenhorn formations during the middle Cenomanian as the seaway expanded eastward.

The stratigraphic distribution of estuarine and marine-influenced sedimentation in the Dakota sequences is schematically portrayed in fig. 7. Each sequence corresponds to a third-order marine cycle of the Western Interior basin, but smaller-scale cycles are apparent in the Dakota succession that are interpreted to be parasequences. These smaller-scale cycles are marked at their base by marine-influenced facies (primarily estuarine), corresponding to marine flooding events. The upper portion of each parasequence is marked by nonmarine deposition, erosional channeling (fluvial downcutting), and soil formation. These phases of deposition correspond with episodes of falling base levels in the fluvial systems, likely coincident with falling sea level in the adjoining Western Interior sea.

\section{Estuarine Depositional Model and Sequence Stratigraphic Implications}

A basic stratigraphic and depositional model of tide-dominated estuarine deposition within the Dakota Formation was presented by Brenner et al. (2000), and this model need not be reiterated in detail here. The recent recognition of an estuarine facies tract within the Dakota sequences has significantly modified our earlier understanding of Dakota sedimentation. The Dakota estuarine facies tract can be subdivided into several zones (Brenner et al., 2000; Dalrymple et al., 1992; White et al., 2000): 1) The outer zone is located adjacent to the estuary mouth and is dominated by marine processes (waves, tides). It can include barrier and shoreface sands, flood-tidal deltas, and tidal sand bodies; 2) The central zone, or estuarine bay, is a relatively low-energy area of mixed fluvial and marine processes; 3) The inner zone is dominated by fluvial processes, and this area has the lowest salinity waters within the estuary. A freshwater tidal zone is recognized in the upstream reaches of the inner zone. Bayhead deltas and tidal bar-channel complexes occur within this zone. The inner to outer estuarine-bay margins can be flanked by tidal wetlands and laterally accreting tidal flats and point bars.

Dakota estuarine sedimentation can be accommodated within a sequence stratigraphic framework, here partly modified from that presented by Brenner et al. (2000) and Brenner et al. (2003). The Transgressive Systems Tract (TST) is marked by marine transgression and eastward estuarine flooding of the older Dakota river valleys. With the accompanying rise in sea level during transgression, base levels rose in the fluvial systems resulting in progressive upstream aggradation of fluvial systems (fig. 8). Because Dakota sediment accumulation rates were relatively low, the maximum eastward expansion of estuaries is interpreted to generally correspond with absolute sea-level highstand in the adjoining Western Interior sea.

Following maximum transgression, sea levels began to fall resulting in the westward retreat of the seaway and shoreface. This resulted in falling base levels within the Dakota fluvial systems and a general downstream migration of fluvial and floodbasin aggradation. With the fall in base levels, progressive fluvial 


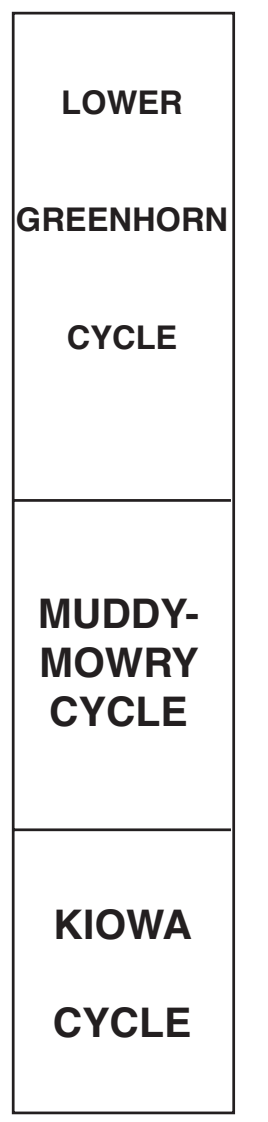

KIOWA CYCLE
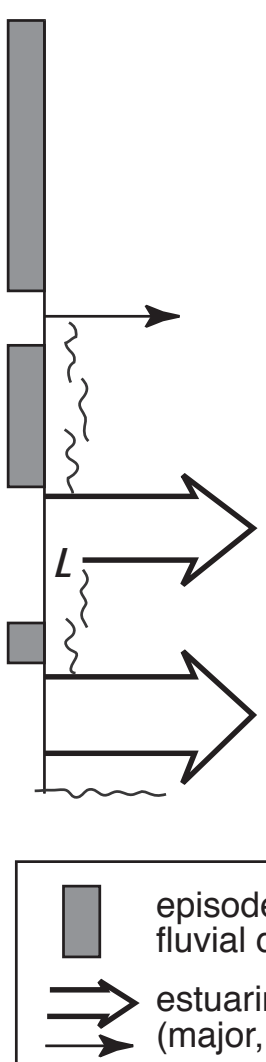

episodes of

fluvial downcutting

estuarine facies

(major, minor)

\section{MUDDY-MOWRY CYCLE}

\section{LOWER GREENHORN CYCLE}

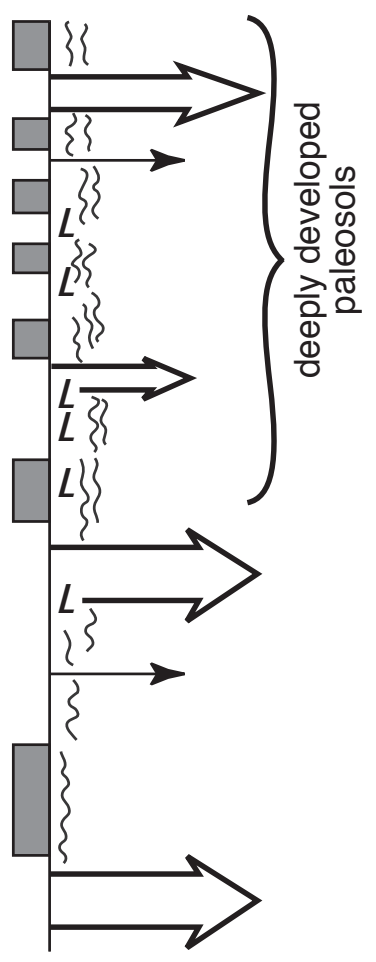

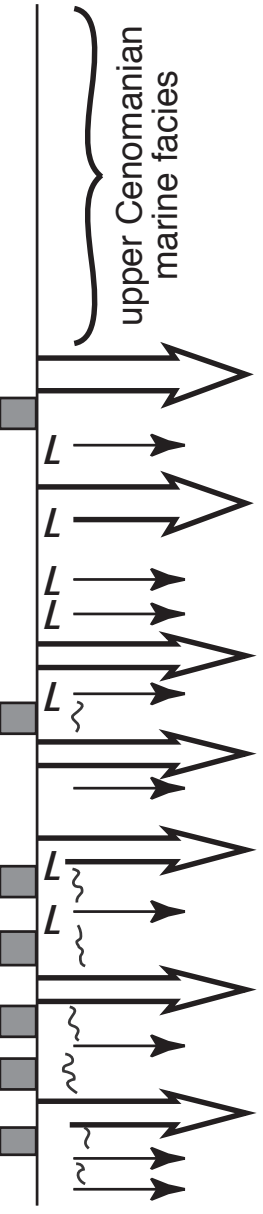

FIGURE 7-Schematic representation of the stratigraphic distribution of marine-influenced and estuarine facies in the Dakota sequences of Iowa, Nebraska, and Kansas. Distributions of illustrated sedimentary facies and fluvial channeling are generalized from the stratigraphic sections shown on figs. 4-6. Shifts between marine influence and nonmarine fluvial channeling and paleosol development likely reflect parasequencescale changes in sea level/base level.

downcutting would proceed from distal to proximal areas of the fluvial systems, and stacked soils could develop in the fluvial flood basins. Estuaries would contract seaward as sea levels fell, and the former estuaries would be infilled by bayhead deltaic and fluvial deposits (fig. 8). The episode of seaward progradation and downstream fluvial aggradation has generally been included within the so-called "Highstand Systems Tract" (HST) in many sequence stratigraphic models. However, in regions of low net sediment accumulation, progradation and downstream fluvial aggradation may not necessarily correspond to times of actual sealevel highstand, and HST may not be an appropriate label in these cases (Witzke et al., 1996d). Some stratigraphers have included other terminology for this systems tract, including the "Regres- sive Systems Tract" (RST) or "Falling Sea Level Systems Tract" (FSLST) (Witzke et al., 1996d).

As the seaway continued to retreat and sea level reached its absolute lowstand in the the adjoining seaway, the Dakota fluvial systems would be marked by their lowest absolute base levels. This would correspond to a time of maximum incision of the fluvial systems and the deepest weathering and soil development in the adjoining interfluves. In areas of low net sediment accumulation, the "Lowstand Systems Tract" (LST) in nonmarine sequences would be predicted to show the deepest levels of erosional channeling and complex stacks of deeply weathered paleosols. Because of the increased potential for extensive pedogenic alteration and erosional incision during lowstand episodes, 




TRANSGRESSION: rising base levels

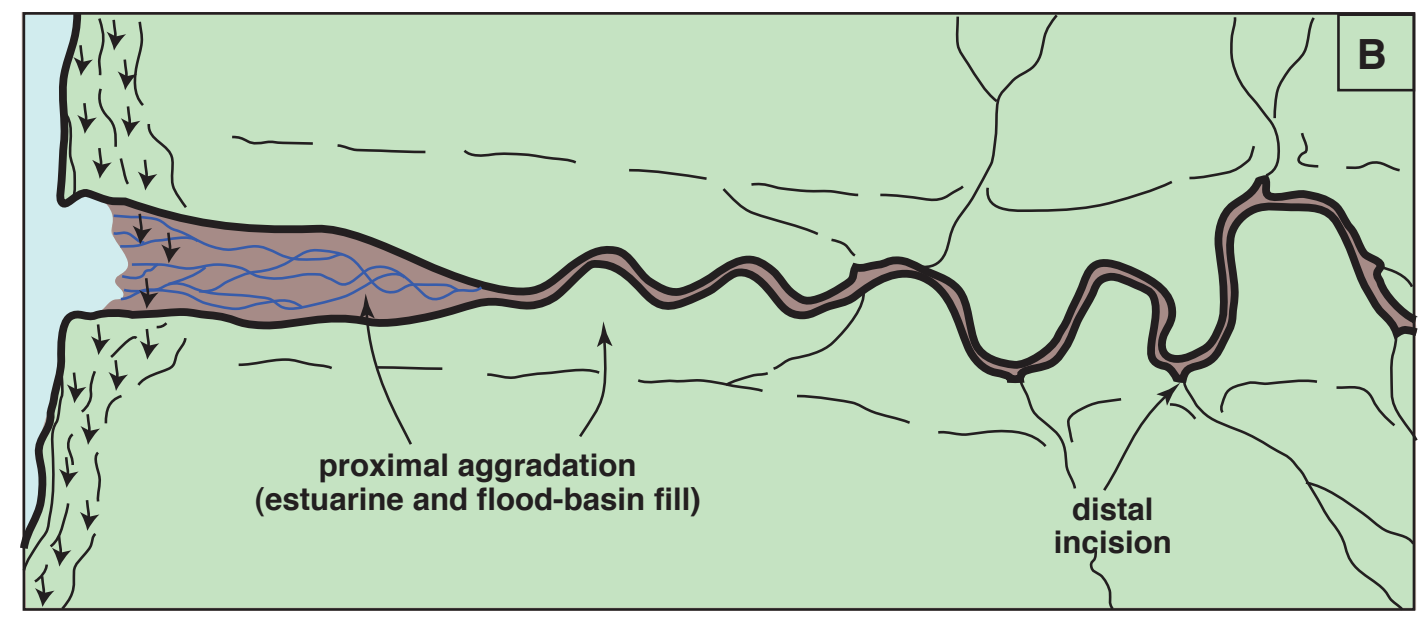

MARINE OFFLAP: lowering base levels

FIGURE 8-Schematic representation of fluvial-estuarine facies of the Dakota Formation during marine transgression and offlap. Rising base levels in the Dakota fluvial systems accompanied sea-level rise, leading to eastward flooding (A) of former fluvial valleys by estuaries and upstream aggradation of fluvial channels. Falling base levels accompanied sea-level fall, resulting in fluvial-deltaic infilling of the former estuaries and upstream incision of fluvial channels (B).

it is possible that evidence for earlier transgressive and estuarine deposits in the sequence may be significantly modified or even removed.

Parasequences are recognized in the Dakota sequences, each marked by smaller-scale changes in sea level or base level within the estuarine and fluvial systems. Many Dakota parasequences show an eastward expansion of estuarine facies at their base, succeeded by the deposition of nonmarine facies and ultimately by paleosol development or fluvial incision (fig. 7). Joeckel (1987) interpreted sea-level change, with resulting base-level change in nonmarine areas, as the cause of soil horizonation in Dakota paleosols of Nebraska. White et al. (2005) suggested that bundles of stacked paleosols in the Dakota sequences may represent parasequence sets.

Some final considerations for Dakota estuarine sedimentation also need to be discussed. Regional paleogradients of the Dakota fluvial systems are difficult to constrain, but Witzke and Ludvigson (1996) argued for low gradients across the eastern coastal lowlands, at maximum $0.3-0.6 \mathrm{~m} / \mathrm{km}$ and probably less. Because the Dakota estuaries extended eastward up the former river valleys tens to hundreds kilometers (up to $300-400 \mathrm{~km}$
[186-248 mi]) from the adjoining sea, the postulated stream gradients would require sea-level changes on the order of 10-100 m (33-328 ft) to create such large estuary systems. Sea-level changes in the mid-Cretaceous on the order of $100 \mathrm{~m}(328 \mathrm{ft})$ may be excessive, which, if true, would indicate even lower fluvial gradients within the Dakota river systems. In general, nonmarine sediment-accumulation rates are very low in the eastern-margin area of the Western Interior, which for lower to middle Cenomanian strata of the upper Dakota Formation averages only about $15 \mathrm{~mm}(0.6 \mathrm{inch}) / 1000 \mathrm{yr}$. Even though runoff from the eastern landmass-dominated freshwater influx to the Western Interior seaway (Slingerland et al., 1996; Witzke and Ludvigson, 1996), sediment supply was correspondingly low. The persistence and widespread extent of estuarine facies in the the Dakota depositional systems were likely enabled by such low rates of sediment influx. The eastward extent and duration of estuarine facies would be constrained by the relative interplay of sea-level change (baselevel change) and rates of sediment accumulation, that is creation versus infilling of accommodation space. In a simple sense, the less the sediment influx, the longer it would take to infill the large Dakota estuaries. 


\section{Sequence Stratigraphic Controls on Carbonate Cementation in the Dakota Formation}

Regional studies of the occurrence and stable isotopic geochemistry of authigenic carbonates in continental to marginalmarine facies of the mid-Cretaceous Western Interior basin have already yielded new insights on perturbations of the global hydrologic cycle during this warm period in earth history (Ludvigson, González, Metzger, et al., 1998; White et al., 2001; Ufnar et al., 2002, 2004b). In short, changes between the Cretaceous and modern $\delta^{18} \mathrm{O}$ gradients of pedogenic siderites along equator-topole transects have been used to argue for an intensified hydrologic cycle in the Cretaceous greenhouse world. This whole line of basic research was pioneered through studies of spherosiderites in the Dakota Formation (Ludvigson et al., 1995; Ludvigson et al., 1996; Ludvigson, González, Metzger, et al., 1998).

Authigenic carbonates in the Dakota Formation commonly occur in other sedimentary contexts. One especially noteworthy mode of occurrence is as thin, laterally extensive sheets of hardcemented rock that are enclosed in otherwise soft, friable sedimentary strata. Similar phenomena have been noted by Taylor et al. $(1995,2000)$ elsewhere in Cretaceous units of the Western Interior basin. Taylor et al. (2000) attributed the sheet cementation to early carbonate diagenesis controlled by sequence stratigraphic processes, a model that is applicable to some examples from the Dakota Formation. In the cases cited by Taylor et al. (1995, 2000), cementation occurred in shoreface sandstones immediately overlain by marine-flooding surfaces. Similar examples of authigenic cementation of fluvial-estuarine deposits immediately below marine-flooding surfaces have also been reported from Cenozoic deposits (Laenen and De Craen, 2004).

Here, we report on the field relationships, petrography, and stable isotopic paleohydrology of thin sheets of laterally extensive carbonate cements in fluvial-estuarine clastic units of the Albian Kiowa-Skull Creek interval of the Dakota Formation.

\section{Field Relationships}

Siderite-Cemented mudstones at THE Ash Grove Cement QUARRY, NEBRASKA - Exposures of Albian fluvial-estuarine strata from the basal Dakota Formation at the Ash Grove cement quarry at Louisville, Nebraska, have been described by Witzke, Ravn, et al. (1996), Witzke, Ludvigson, Brenner, et al. (1996), and Joeckel et al. (2005). Tidal rhythmites in estuarine mudrocks containing marine palynomorphs from this locality (fig. 9) were also described by Brenner et al. (2000).

Carbonate cements are described from the lower of two marine palynomorph-bearing estuarine mudrock units (unit 2 or Kd2; figs. 9, 10). These include a massive, hard-cemented horizon (AGP-LU2) with sheet geometry just above the unit 1-unit 2 contact (the $\mathrm{Kd} 1-\mathrm{Kd} 2$ contact in fig. 11A), and a hard-cemented mudstone bed (AGP-MU2) with sheet geometry from inclined heterolithic strata from the middle part of unit 2 (fig. 9; $\mathrm{Kd} 2$ in figs. 10 and 11A). Discrete meter-scale concretionary bodies also occur in unit $2(\mathrm{Kd} 2)$, but have not yet been studied. The hard-cemented zones at the base and middle part of unit 2 are of special interest. Exposures in the north and south quarry walls show the lateral continuity of the sheet-cemented zone at the base of unit
2 , and the drilling of three research cores of units 2-5 by hollowstem auger in 1995 all were terminated by auger refusal at the top of this hard-cemented zone. This sheet-cemented zone ranges between 30 to $60 \mathrm{~cm}$ (12-23 inches) in thickness. It is probably analogous to the thin, laterally extensive carbonate-cemented horizons beneath marine-flooding surfaces described by Taylor et al. $(1995,2000)$.

Siderite-cemented mudstone at the Long Creek SecTION-Exposures of fluvial-estuarine mudstones from the base of the Nishnabotna Member of the Dakota Formation at the Garst Farm Resorts (recently redesignated as the Whiterock Conservancy) were described by Witzke and Ludvigson $(1996,1998)$ and Brenner et al. (2003). An especially instructive exposure of estuarine mudrocks along Long Creek in the Garst properties was first described by Phillips and White (1998). These mudrocks contain a sparse marine-influenced ichnofauna and tidally modulated heterolithic siltstone-mudstone strata that show marine influences on deposition (Brenner et al., 2003). They represent the most landward marine influences of the Late Albian Kiowa-Skull Creek marine cycle that are currently known.

A hard-cemented ledge (sample LC-1, fig. 9) at the contact between a lateral accretion set of inclined heterolithic strata (unit 1 in fig. 9; Kdla in fig. 12A) was examined for this study. This ledge extends throughout the width of the section. A scanned image of a thin section cut from this sideritic ironstone (fig. 12B) shows that carbonate cements pervade a burrowed laminite. Petrographic examination of this bed (fig. 12C, D) shows that it is a siltstone-claystone laminite cut by Cylindrichnus burrows, all of which are pervasively cemented by early diagenetic blocky equant siderite.

Siderite-cemented Nishnabotna Sandstone in the HaWARDEN (D-7) CORE - This important stratigraphic reference section was described by Whitley and Brenner (1981), Witzke and Ludvigson (1994), and Brenner et al. (2000). The core (fig. 9) fully penetrates the Dakota Formation, and thin bands of sideritecemented sandstones were recovered from the lower part of the Albian Nishnabotna Member that were the subject of an earlier brief report (Phillips et al., 1998).

\section{Petrographic Relationships}

Witzke and Ludvigson (1994) and Ludvigson (1999) showed that sandstones in the Dakota Formation are mineralogically mature quartzarenites. Detrital carbonate-rock fragments are not present in the unit (Ludvigson, 1999). For this reason, authigenic carbonates in the Dakota Formation are easily isolated for isotopic studies through micromilling of polished thin-section billets with carbide dental burrs.

Siderite cements examined for this study (fig. 9) are all interpreted to be early diagenetic, synsedimentary features, based in part on field evidence for the sedimentary erosion and entrainment of carbonate-cemented intraclasts, but mainly on petrographic evidence from sandstone-siltstone units that the cements filled an open framework of primary sediment porosity prior to any significant reduction of intergranular volume through com- 

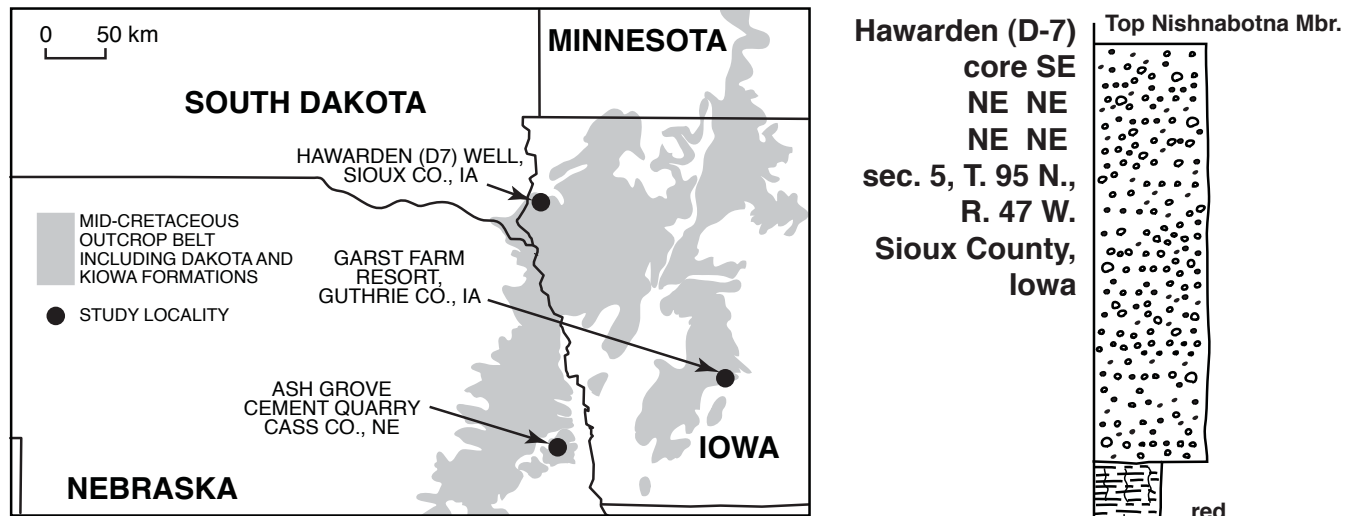

Denotes sampled interval

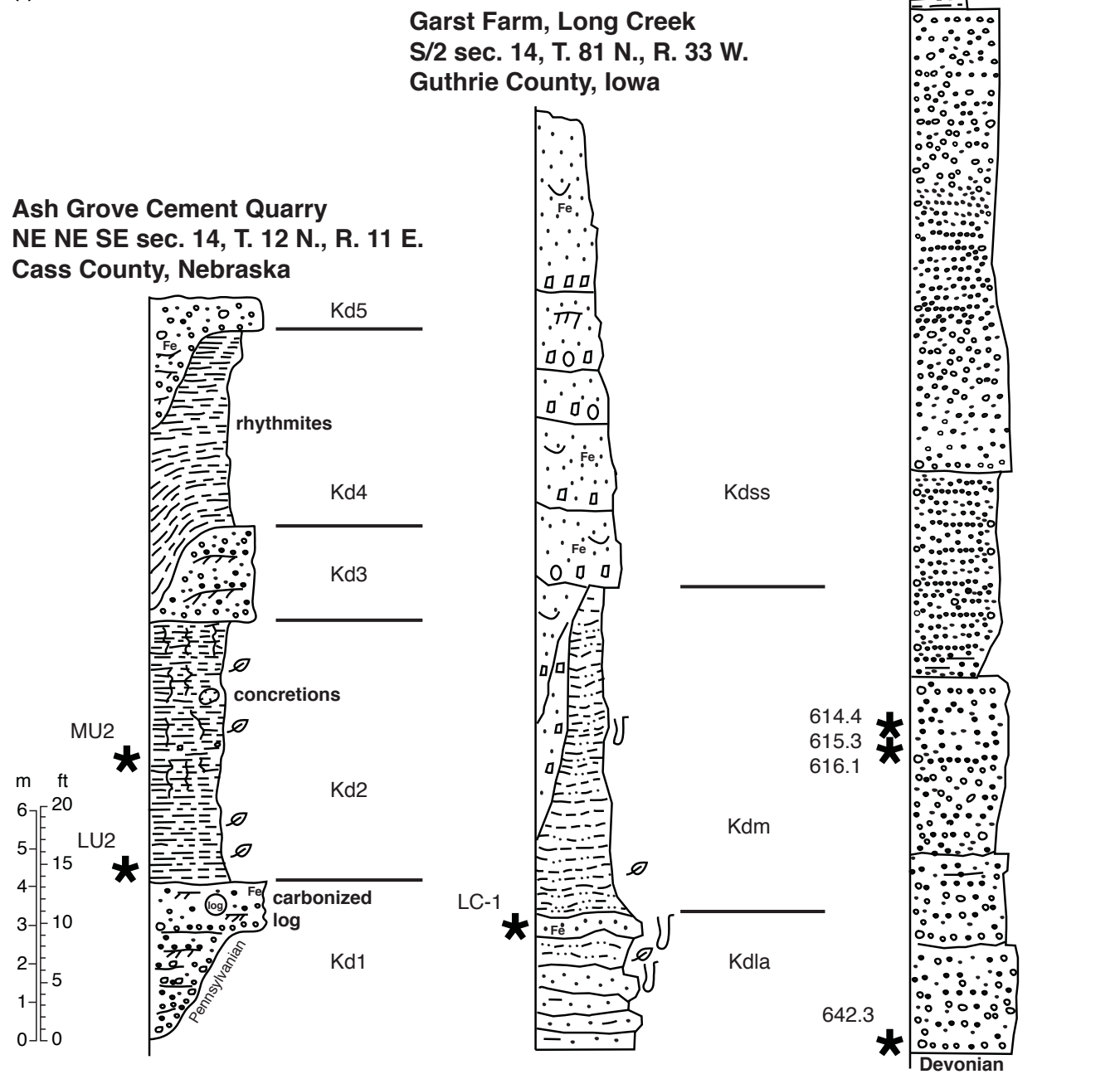

FIGURE 9-Location map and graphic logs of stratigraphic sections showing the positions of Albian fluvial-estuarine units with authigenic siderites that were sampled for petrographic, stable isotopic, and diagenetic investigations of the paleohydrology of the Kiowa-Skull Creek interval of the Dakota Formation.

paction (Paxton et al., 2002). These units probably had original intergranular volumes (IGVs) of about 40\% (Houseknecht, 1987), and the IGVs (also known as minus-cement porosities) in them, as determined by point counting, range between $36 \%$ to $68 \%$ (table 8). Taylor et al. (1995) and Taylor et al. (2000) reported high IGVs around $40 \%$ from their sequence-bounding sheet-cemented zones and argued for synsedimentary carbonate cementation. The occlusion of large volumes of original intergranular pore space by the siderite cements is consistent with near-surface, early synsedimentary diagenesis. For example, the $56.5 \%$ and $68 \%$ IGVs measured from ACP-LU2 and LC-1 (table 8), respectively, are compared with published data sets from Houseknecht (1987) in fig. 13. The main point shown by this comparison is that the IGVs from these beds are well outside the norms that are reported from ancient coarse-grained clastic rocks. The abnormally large IGV values in these rocks (fig. 13) probably resulted from displacive growth of siderite crystals under low confining pressures, coincident with near-surface cementation. 

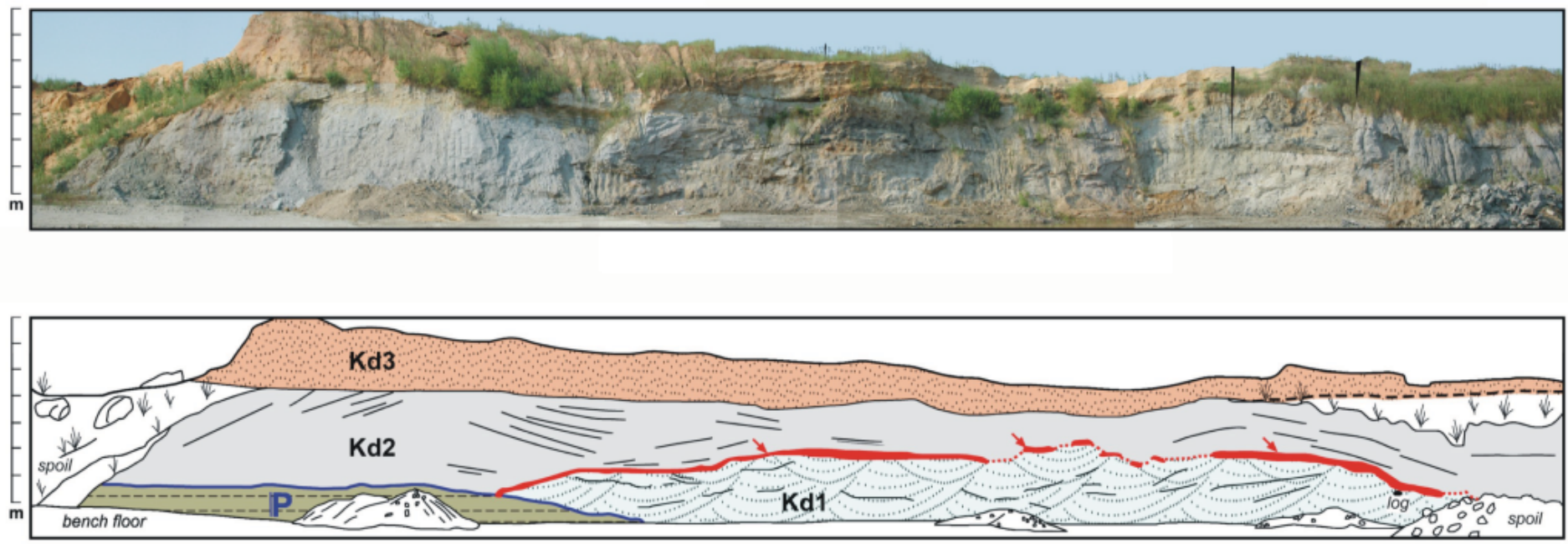

FIGURE 10-Panoramic photomosaic of a high wall in the Kiowa-Skull Creek interval of the Dakota Formation in the Ash Grove cement quarry in Louisville, Nebraska, in summer 2002, looking north showing the cemented zone (arrows) at Kd1-Kd2 contact. Photomosaic is shown in the upper panel, and an interpretive line tracing is shown in the lower panel. $\mathrm{Kd} 1 \mathrm{is}$ a conglomeratic fluvial sandstone unit, and $\mathrm{Kd} 2$ is an estuarine heterolithic unit that has yielded abundant marine palynomorphs and is characterized by IHS lateral accretion beds that extend throughout the unit (Brenner et al., 2003; Joeckel et al., 2005). The Kd1-Kd2 contact is interpreted to be a marine-flooding surface. Joeckel et al. (2005, p. 464) illustrated Skolithos-type burrows at the top of Kd1. Joeckel et al. (2005) further showed that both of these units fill a paleovalley that is delimited by the extent of the workings at the Ash Grove cement quarry. Note that Kd1 is overlapped by Kd2 in the left side of the photomosaic, and that both units rest on Pennsylvanian limestone strata. $\mathrm{Kd} 3$ is a crossbedded gravelly sandstone that intertongues with estuarine mudrocks elsewhere in the quarry (Brenner et al., 2003, p. 445; Joeckel et al., 2005, p. 462).
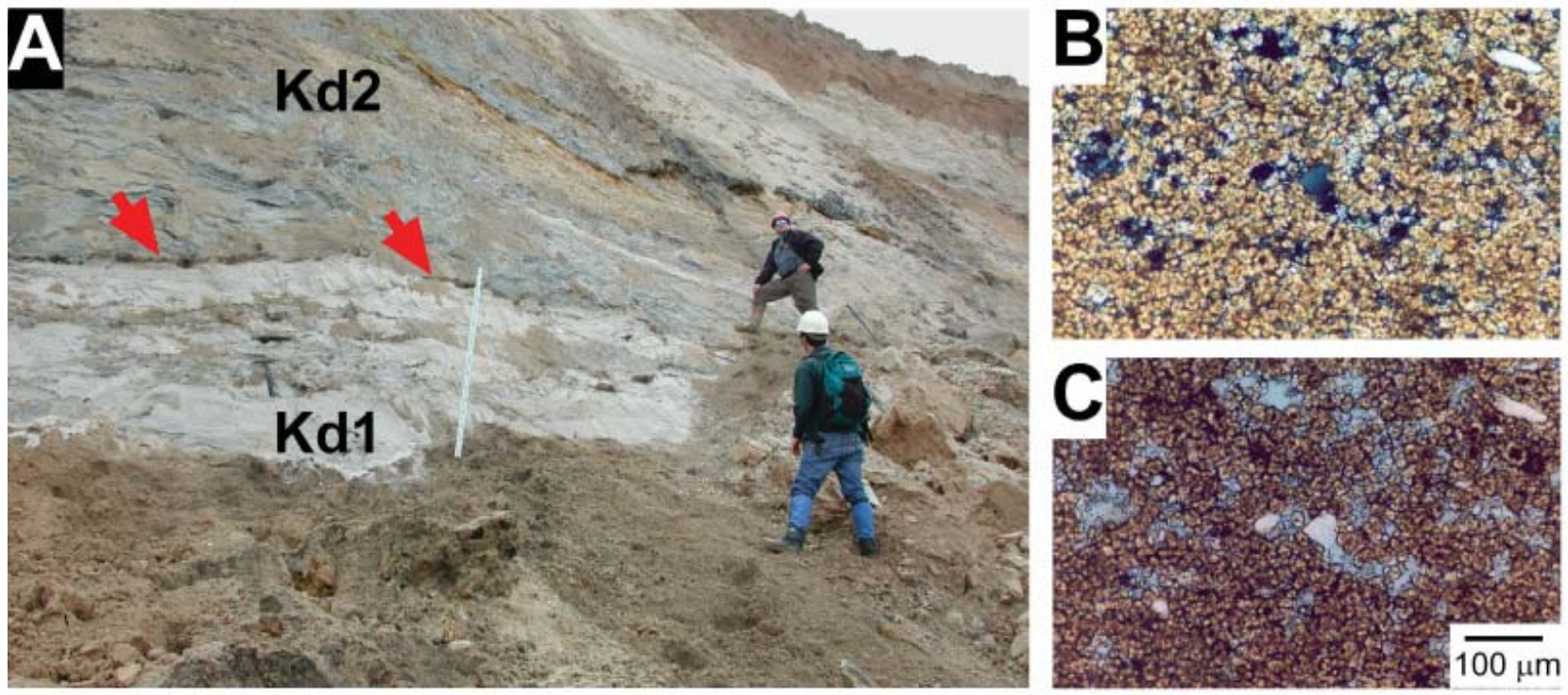

FIGURE 11-A) Close-up view of cemented zone at the Kd1-Kd2 contact (arrows) at the Ash Grove cement quarry looking at the south wall of the

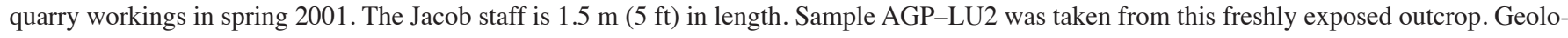
gists Phillips (back to camera) and Ludvigson (facing camera) are shown to the right. Sample AGP-MU2 was taken from siderite-cemented mudstones in an IHS unit shown directly above Ludvigson's head. B) Cross-polarized light micrograph of sample AGP-LU2 showing microcrystalline (10-20 microns) siderite cements pervading mudstone matrix. C) Same field of view, plane-polarized light micrograph. Note angular detrital quartz-silt grains (white). 

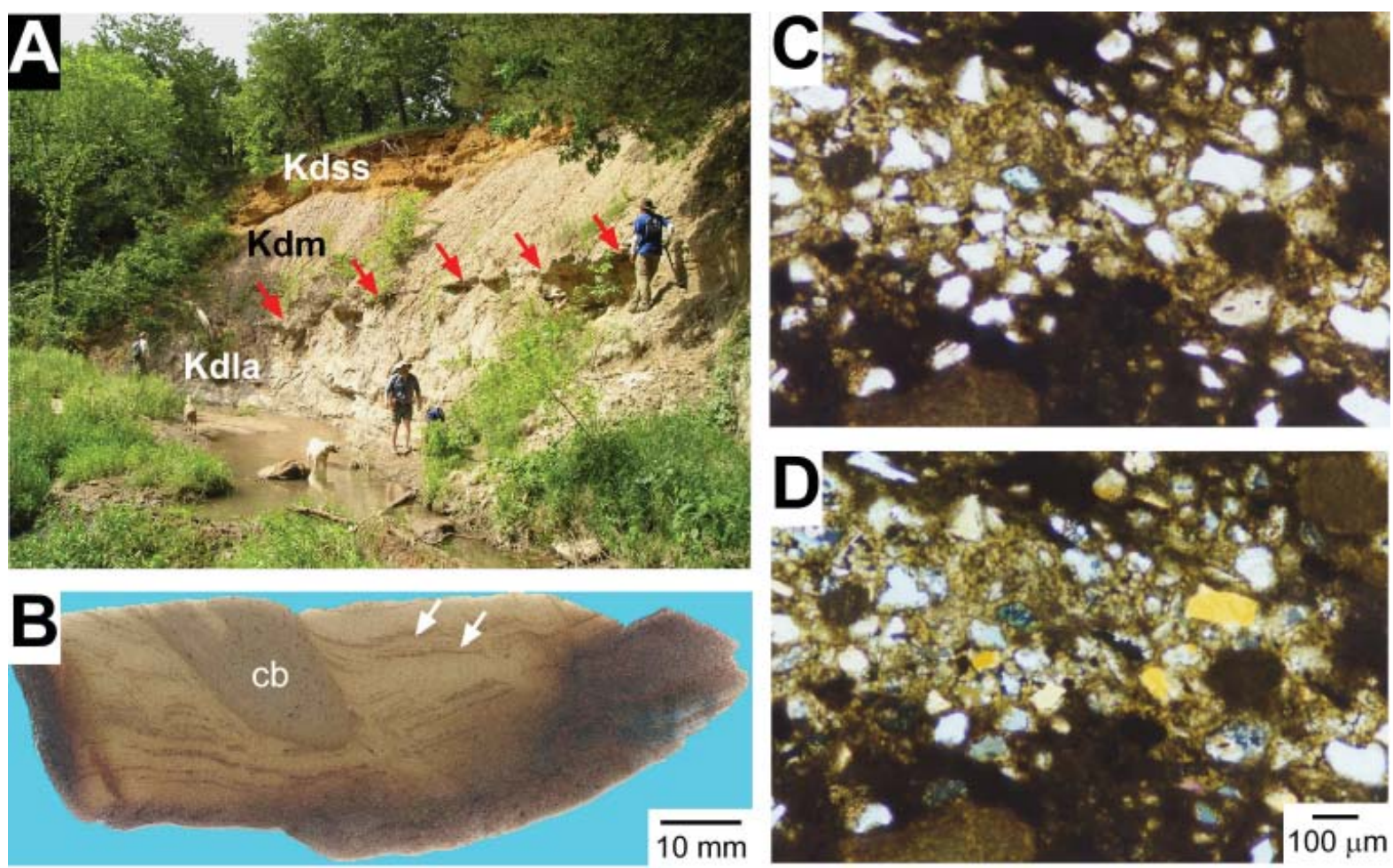

FIGURE 12-A) Field photograph of the siderite sheet-cemented zone capping the IHS lateral accretion unit Kdla (red arrows) at the LC-1 exposure along Long Creek at the Garst Farms Resort. Sample LC-1 was taken from this hard-cemented bed. B) Scanned image of a thin section of siderite-cemented ironstone from sample LC-1, showing cemented Cylindrichnus (?) burrow (cb) and clay-drape laminae distorted by soft-sediment deformation (white arrows). Note that in the margins of the ironstone sample, oxidation from modern weathering has replaced the pervasive siderite cements by opaque oxides. C) Plane polarized-light micrograph showing a siltstone lamina enclosed by mud-drape laminae. Note the high intergranular volume (IGV) greater than $50 \%$ in this unit. D) Same field of view, cross-polarized light micrograph.

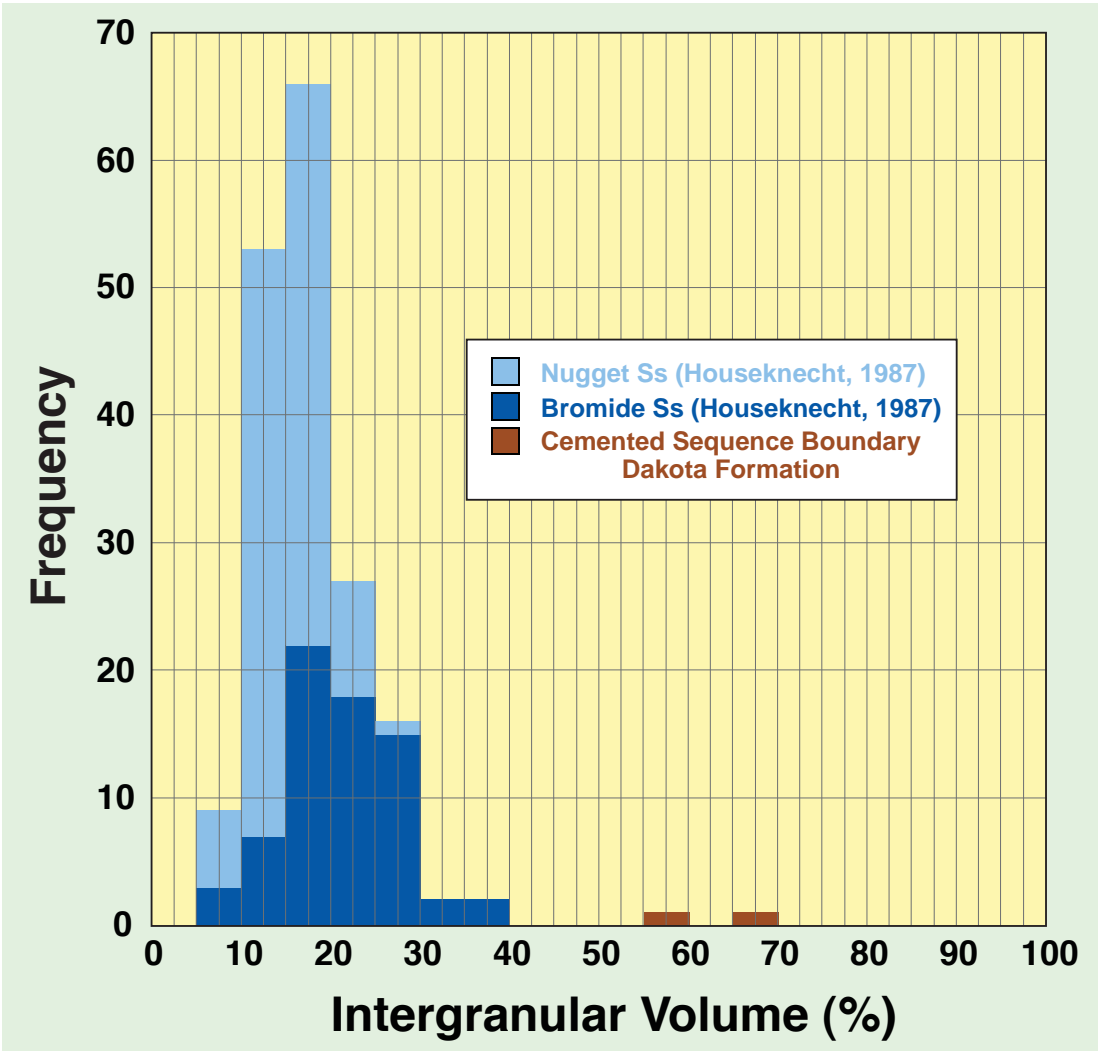

FIGURE 13-Histogram of intergranular volumes, comparing published datasets from ancient sandstones (Houseknecht, 1987) and those measured from siderite-cemented zones from parasequence-bounding surfaces in the Kiowa-Skull Creek interval of the Dakota Formation. 
New Insights on the Sequence Stratigraphic Architecture of the Dakota Formation, Ludvigson et al.

TABLE 8-Point-count data with intergranular volumes from siderite-cemented rocks in the Dakota Formation.

\begin{tabular}{|c|c|c|c|c|c|c|}
\hline $\begin{array}{l}\text { SAMPLE } \\
\text { NUMBER }\end{array}$ & $\begin{array}{l}\text { FRAMEWORK } \\
\text { GRAINS }\end{array}$ & $\begin{array}{l}\text { DETRITAL } \\
\text { MUD }\end{array}$ & $\begin{array}{l}\text { SIDERITE } \\
\text { CEMENTS }\end{array}$ & $\begin{array}{l}\text { OTHER } \\
\text { CEMENTS }\end{array}$ & POROSITY & $\begin{array}{l}\text { INTERGRANULAR } \\
\text { VOLUME (IGV) }\end{array}$ \\
\hline D7-614.6 & 58.67 & 0 & 31.33 & 0.66 & 9.33 & 41.32 \\
\hline D7-615.3 & 64.01 & 0 & 23.67 & 2.00 & 10.33 & 36.0 \\
\hline D7-616.1 & 52.67 & 0 & 16.00 & 2.00 & 29.33 & 45.53 \\
\hline D7-618 & 68.66 & 0 & 26.33 & 0.33 & 4.67 & 31.33 \\
\hline D7-642.3 & 60.66 & 0 & 33.34 & 0.67 & 5.33 & 39.34 \\
\hline D7-642.6 & 65.33 & 0 & 22.00 & 0.33 & 12.33 & 34.66 \\
\hline D7-642.8 & 62.99 & 0 & 26.00 & 0.67 & 10.33 & 37.0 \\
\hline LC-1 & 32.00 & $39.50 * *$ & 23.50 & 5.00 & 0 & $28.5(68 *)$ \\
\hline AGP-LU2 & 43.50 & 0 & 56.50 & 0 & 0 & 56.5 \\
\hline AGP-MU2 & 4.50 & $94.50 * *$ & $0^{*}$ & 0.50 & 0.50 & -- \\
\hline
\end{tabular}

*point counts exclusively in coarser-grained laminae

**muds are pervaded by microcrystalline siderite cement

\section{Stable Isotopic Investigations}

Methods - Rock samples examined for this study were impregnated with blue-dyed epoxide resins and cut into micropolished thin sections and thin slabs for microsampling. They were assessed by polarized light and cathodoluminescence petrography, and some thin sections were stained with alizarin Red-S and potassium ferricyanide to confirm identifications of carbonate minerals. While multiple siderite cements were distinguished by crystal morphology in some successive pore-filling sequences, no other carbonate cements were identified in these samples. Selected siderite cements were microdrilled by dental carbide burrs of 0.5-mm diameter on a microscope-mounted drill assembly, and resulting powdered samples of several micrograms were roasted for one hour in vacuum to remove volatile contaminants. Samples were reacted at $73^{\circ} \mathrm{C}$ with anhydrous phosphoric acid in a Finnigan Kiel III automated carbonate reaction device coupled to the inlet of a Finnigan MAT 252 stable isotope mass spectrometer at the Paul H. Nelson Stable Isotope Laboratory at the University of Iowa. Data are reported in standard delta $(\delta)$ notation in parts per mil relative to the VPDB isotope standard. Daily analyses of interlaboratory standards show a precision of better than $0.1 \%$ o for both carbon and oxygen isotopes. The $\delta^{18} \mathrm{O}$ values for siderite were corrected for the temperature-dependent fractionation between acid-liberated $\mathrm{CO}_{2}$ and siderite using the experimental data of Carothers et al. (1988). Estimates of paleoground-water $\delta^{18} \mathrm{O}$ values relative to SMOW were calculated using the experimental siderite-water fractionation relation of Carothers et al. (1988).

RESUlTs - Carbon and oxygen isotope plots of data from siderite cements in the Dakota Formation of Iowa and Nebraska are shown in fig. 14. While more detailed assessments of these data are pending in future publications, some general relationships are discussed here. Syndepositional cements in the Dakota Formation throughout the region have $\delta^{18} \mathrm{O}$ values that tightly cluster around $-5 \%$, while the $\delta^{13} \mathrm{C}$ values are much more variable, ranging between -17 to $-1 \%$. The aggregate diagenetic trend for these data can be simply referred to as a meteoric siderite line. The general meaning of such a diagenetic trend is that the cements in question precipitated from a shallow, stable ground-water system in which the fluid $\delta^{18} \mathrm{O}$ compositions and temperatures changed very little, while the $\delta^{13} \mathrm{C}$ variations indicate that dissolved inorganic carbon in early diagenetic systems was contributed from multiple sources. Meteoric siderite lines, meteoric spherosiderite lines (Ludvigson, González, Metzger, et al., 1998), and meteoric calcite lines (Lohmann, 1988) are all useful paleoclimatic indicators, as they are interpreted to result from the isotopic equilibrium crystallization of authigenic carbonates from shallow meteoric ground waters. Accordingly, they integrate the local mean annual $\delta^{18} \mathrm{O}$ of paleoprecipitation, at the local mean annual temperature (Hays and Grossman, 1991).

A covariant trend toward $\delta^{13} \mathrm{C}$ and $\delta^{18} \mathrm{O}$ enrichment at the 614.4-ft to 616.1-ft level in the Hawarden (D7) core (fig. 14) is interpreted to indicate possible fluid mixing between meteoricand marine-source waters. Pyrite inclusions and euhedral pyrite pore fillings are consistently noted as minor cement phases in cemented Nishnabotna sandstones (see "other cements" in table 8 ), suggesting that anaerobic reduction of seawater sulfate from brackish pore fluids overlapped with the deposition of these cements. The precipitation of siderite cements as the dominant reduced iron mineral phase, and the tangential approach of the covariant isotopic trend to the meteoric siderite line trend (note that $\delta^{18} \mathrm{O}$ values from the D7 core samples range only up to about $-4 \%$ ) indicate that the diagenetic fluids were dominantly meteoric in origin and probably consisted of much less than $25 \%$ seawater (see Ufnar et al., 2004a, p. 139).

Discussion-The meteoric siderite line $\delta^{18} \mathrm{O}$ value of $-5 \%$ o from fluvial-estuarine deposits of the Nishnabotna Member compares to a meteoric spherosiderite line value of $-4.2 \%$ from spherosiderites in a plinthic paleosol developed in correlative fluvial-estuarine deposits at the Camp Jefferson section (Brenner et al., 2000, p. 873) in southeast Nebraska. Spherosiderites from plinthic paleosols in fluvial-estuarine deposits of the overlying Late Albian Muddy cycles at the Yankee Hill claypits west of Lincoln, Nebraska, yield meteoric spherosiderite line values ranging between -4.4 to $-3.6 \%$. Farther to the north in the Sioux City, Iowa, area, spherosiderites from the Muddy cycles and the lower part of the overlying Late Albian-Turonian Greenhorn marine cycle have meteoric spherosiderite line values that range between -5.3 to $-2.9 \%$ (White et al., 2005). 
NEBRASKA



IOWA

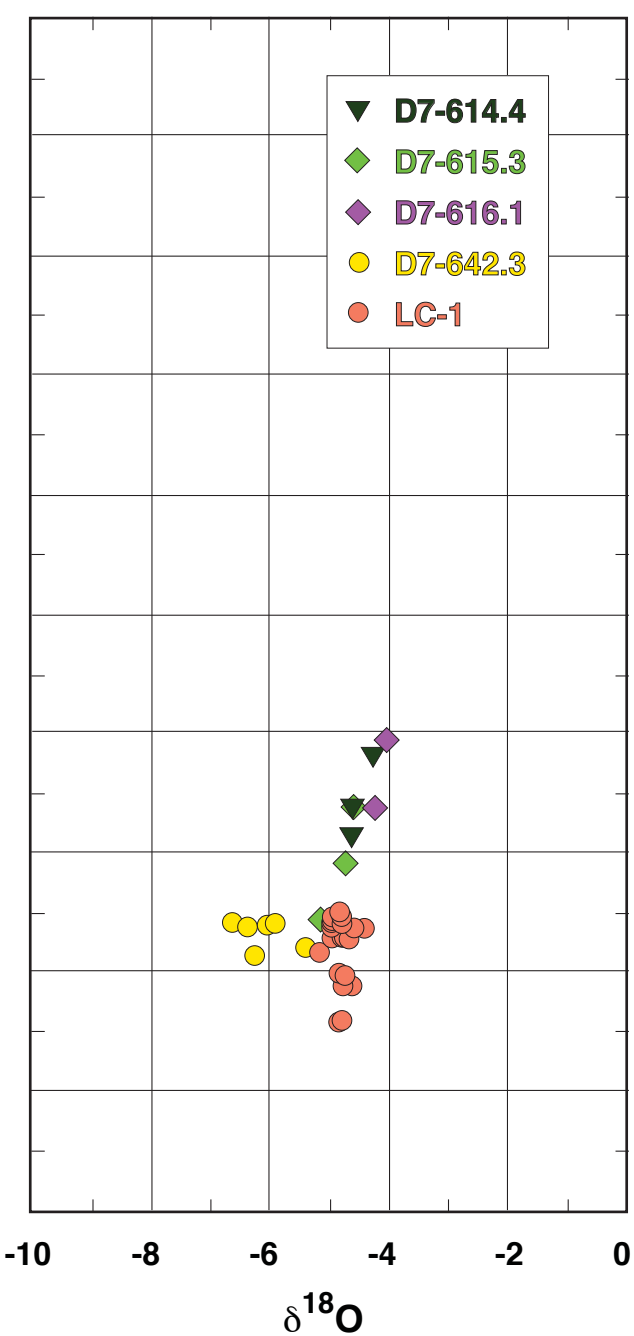

FIGURE 14-Carbon-oxygen isotope plot of data from Albian authigenic siderites in the Kiowa-Skull Creek interval in the Dakota Formation. The $\delta^{18} \mathrm{O}$ and $\delta^{13} \mathrm{C}$ values are in per mil variations from the VPDB carbonate isotope standard.

In short, siderites from cemented zones in fluvial-estuarine facies of the Dakota Formation have $\delta^{18} \mathrm{O}$ values that overlap with, but are generally lighter than those from spherosiderites in the interbedded paleosols. Phillips et al. (2007) argued that differences between the fluid $\delta^{18} \mathrm{O}$ compositions determined from pedogenic spherosiderites and regional fluvial-estuarine paleoaquifers in the "Muddy cycle" of the Dakota Formation resulted from differences in the sizes of the catchment basins that recharged their respective paleoground-water systems. The lighter $\delta^{18} \mathrm{O}$ values of cements in Dakota fluvial-estuarine paleoaquifers are attributed to "continental effects" (sensu Rozanski et al., 1993) on the ${ }^{18} \mathrm{O}$ composition of precipitation over the interior of the large eastern landmass that drained into the Western Interior foreland basin. This far inland precipitation was delivered by runoff and shallow ground-water flow into the large-scale fluvial systems that drained into the Western Interior seaway. Dutton et al. (2005) presented actualistic isotopic data that verify this partitioning of North American local precipitation (heavier $\delta^{18} \mathrm{O}$ values) and regional runoff (lighter $\delta^{18} \mathrm{O}$ values), and referred to this phenomenon as "catchment effects." The practical importance of this phenomenon is that river waters in large continents have lower $\delta^{18} \mathrm{O}$ values than the locally recharged ground waters beneath their immediately adjacent interfluve areas.

Estimates of the ground-water $\delta^{18} \mathrm{O}$ compositions from which the siderite cements in fluvial-estuarine facies of the KiowaSkull Creek-Nishnabotna interval were precipitated are shown in fig. 15. These estimates depend on independent estimates of the temperatures of the shallow paleoground waters from which the siderites precipitated-usually a close approximation of the mean annual paleotemperature. We here use the envelope of empirical estimates of Cretaceous paleotemperatures at each paleolatitude from Barron (1983). At estimated zonal mid-Cretaceous mean annual temperatures for $34^{\circ} \mathrm{N}$ paleolatitude ranging between 21 to $31^{\circ} \mathrm{C}$, and using the siderite-water ${ }^{18} \mathrm{O}$ fractionation relation of Carothers et al. (1988), these ground waters are estimated to have had $\delta^{18} \mathrm{O}$ compositions ranging between -8.5 to $-4.2 \%$ SMOW. These estimated ground-water values compare to an estimated coastal paleoprecipitation value of $-8.1 \%$ at $34^{\circ} \mathrm{N}$ paleolatitude by White et al. (2001), based on a mid-latitude linear regression of meteoric spherosiderite $\delta^{18} \mathrm{O}$ compositions, but used a lower climate model-derived paleotemperature of about $15^{\circ} \mathrm{C}$. At this same lower paleotemperature estimate of $15^{\circ} \mathrm{C}$, the Iowa siderite 



FIGURE 15-Calculated ranges of Albian paleoground waters determined from authigenic siderites in the Kiowa-Skull Creek interval of the Dakota Formation. The $\delta^{18} \mathrm{O}$ values are in per mil variations from the SMOW water isotope standard. They were calculated using the average $\delta^{18} \mathrm{O}$ values from siderites at specific stratigraphic positions (see figs. 9 and 14), the range of estimated Cretaceous mean annual surface temperatures, and the temperature-dependent siderite-water ${ }^{18} \mathrm{O}$ fractionation relationship of Carothers et al., 1988. A - Nebraska locales; B - Iowa locales. 
cements yield even lower estimated ground-water compositions ranging between -10 to about $-8 \%$ sMOW. Once again, the estimated ground-water $\delta^{18} \mathrm{O}$ values from fluvial-estuarine paleoaquifers of the Kiowa-Nishnabotna interval overlap with, but are generally lighter than those from spherosiderites at this paleolatitude. The significance of this observation is that authigenic minerals analyzed from differing sedimentary facies in the same fluvial depositional system will yield differing estimates of the $\delta^{18} \mathrm{O}$ of ground water.

As discussed by Ludvigson, González, Metzger, et al. (1998), White et al. (2001), and Ufnar et al. (2002), mid-Cretaceous spherosiderites have $\delta^{18} \mathrm{O}$ values that are notably lighter than those calculated for the same latitudes using modern temperature and precipitation data (Rozanski et al., 1993). White et al. (2001) argued that these data call for substantially increased precipitation in the Cretaceous, and that average mid-Cretaceous precipitation rates in this region ranged between 2,500 to $4,100 \mathrm{~mm} / \mathrm{yr}$. Oxygen-isotope mass balance modeling experiments simulating the hydrologic cycle of the Cretaceous northern hemisphere (Ufnar et al., 2002) suggest that the estimates of White et al. (2001) are probably conservative, and that even substantially higher Cretaceous precipitation rates are required to accommodate these data. These relationships are highly relevant to the paleoenviron- mental reconstruction of the ancient fluvial systems of the Dakota Formation. Analogies to modern fluvial systems need to account for major mass balance changes in the global hydrologic cycle in the greenhouse world of the mid-Cretaceous.

Of special note is the fact that thin, laterally extensive sheetcemented zones (see arrows in figs. 10,11, and 12), are interpreted to have formed just beneath marine-flooding surfaces as in Taylor et al. (2000), but precipitated from pore waters that are interpreted to have been purely meteoric in origin (fig. 15). We suggest that early carbonate cementation was coeval with fresh ground-water discharge upward through the estuarine-sediment column. This could even include scenarios involving the far offshore intrusion of fresh ground-water systems, with discharge through submarine springs beneath the brackish-water columns of contemporary estuaries. This general concept represents a variation on the idea of the "subterranean estuary" as explained by Moore (1999). Greatly enhanced Cretaceous mid-latitude precipitation rates interpreted from the oxygen isotopic data (Ufnar et al., 2002) suggest that coastal ground-water-recharge rates, flow-through volumes, and discharge rates also increased, so that ground-water fluxes into offshore shallow-marine deposits of the cratonic margin of the Western Interior seaway might have been much greater than those indicated by any modern studies.

\section{Conclusions}

An update on the palynostratigraphy of the Dakota Formation is presented, identifying four distinctive Albian-Cenomanian palynostratigraphic zones in the areas of Iowa, Nebraska, and Kansas. The widespread occurrence of marine palynomorphs in all of the sequences of the Dakota Formation indicate that fluvialestuarine depositional processes operated throughout the accumulation of the unit.

Three major cycles of marine-influenced deposition are recognized in the largely fluvial succession of the Dakota Formation of Iowa, Nebraska, and Kansas. In ascending order, these are 1) the late Albian Kiowa-Skull Creek Cycle, (2) the latest Albian "Muddy-Mowry Cycle," and (3) the Cenomanian lower Greenhorn Cycle. These cycles of deposition are broadly correlated throughout the study area and also are recognized in other parts of the Cretaceous North American Western Interior basin.

Early meteoric phreatic siderite cements in fluvial-estuarine sedimentary facies of the Kiowa-Skull Creek interval of the Dakota Formation in western Iowa and eastern Nebraska have meteoric siderite line values that are similar to the lightest $\delta^{18} \mathrm{O}$ values measured from spherosiderites in laterally equivalent paleosols. Collectively, these isotopic data suggest that the mid-latitudes of the Albian greenhouse world received substantially greater mean annual rainfall than in the modern climate system, a factor that must be considered in assessing the dynamics of fluvial systems of the Cretaceous Period.
Laterally extensive thin zones of pervasive carbonate cementation are noted in fluvial estuarine deposits of the Dakota Formation. They are suggested to have formed as synsedimentary cements below estuarine marine-flooding surfaces, in settings related to discharging paleoground waters. Their occurrence may have very important implications for the existence of diagenetic barriers and baffles to modern ground-water flow in the Dakota Aquifer System. This paradigm of carbonate cementation as controlled by sequence stratigraphic development offers considerable promise for the future research development of more refined predictive models for diagenetic controls on fluid compartments in ground-water aquifers and petroleum reservoirs in Cretaceous sandstones.

\section{Acknowledgments}

This work was supported by NSF grant EAR 96-28128. The work of Phillips was supported by a University of Iowa Department of Education GAANN Ph.D. fellowship, and a Carver Initiative Seed Grant for Scientific and Engineering Research. We thank our colleagues Scott Carpenter, Tim White, and David Ufnar for their long-term efforts in contributing to our collective research program. We thank John Holbrook and George Shurr for constructive review comments that substantially improved the presentation of our results. Finally, we thank Mark Schoneweis for his assistance on graphic presentation. 


\section{References}

Agasie, J. M., 1969, Late Cretaceous palynomorphs from northeastern Arizona: Micropaleontology, v. 15, p. 13-30.

Archangelsky, S., 1977, Balmeiopsis, nuevo nombre generico para el palinomorfo Inaperturopollenites limbatus Balme, 1957: Ameghiniana, v. 14, p. 122-125.

Barron, E. J., 1983, Warm, equable Cretaceous - The nature of the problem: Earth Science Reviews, v. 19, p. 305-338.

Brenner, G. J., 1963, The spores and pollen of the Potomac Group of Maryland: Maryland Department of Geology, Mines, and Water Resources, Bulletin 27, p. 1-215.

Brenner, R. L., Bretz, R. F., Bunker, B. J., Iles, D. L., Ludvigson, G. A., McKay, R. M., Whitley, D. L., and Witzke, B. J., 1981, Cretaceous stratigraphy and sedimentation in northwest Iowa: Iowa Geological Survey, Guidebook Series No. 4, 172 p.

Brenner, R. L., Ludvigson, G. A., Witzke, B. J., Zawistoski, A. N., Kvale, E. P., Ravn, R. L., and Joeckel, R. M., 2000, Late Albian Kiowa-Skull Creek marine transgression, lower Dakota Formation, eastern margin of Western Interior seaway, U.S.A.: Journal of Sedimentary Research, v. 70, p. 868-878.

Brenner, R. L., Ludvigson, G. A., Witzke, B. J., Phillips, P. L., White, T. S., Ufnar, D. F., Gonzalez, L. A., Joeckel, R. M., Goettemoeller, A., and Shirk, B. R., 2003, Aggradation of gravels in tidally influenced fluvial systems, upper Albian (Lower Cretaceous) on the cratonic margin of the North American Western Interior foreland basin: Cretaceous Research, v. 24, no. 4, p. 439-448.

Carpenter, S. J., Erickson, J. M., Lohmann, K. C., and Owen, M. R., 1988, Diagenesis of fossiliferous concretions from the Upper Cretaceous Fox Hills Formation, North Dakota: Journal of Sedimentary Petrology, v. 58, p. 706-723.

Carothers, W. W., Adami, L. H., and Rosenbauer, R. J., 1988, Experimental oxygen isotope fractionation between siderite-water and phosphoric acid liberated $\mathrm{CO}_{2}$-siderite: Geochimica et Cosmochimica Acta, v. 32, p. 2,445-2,450.

Dalrymple, R. W., Zaitlin, B. A., and Boyd, R., 1992, Estuarine facies models - Conceptual basis and stratigraphic implications: Journal of Sedimentary Petrology, v. 62, p. 1,130-1,146.

Davies, E. H., 1985, The Anemiacean, Schizaeacean and related spores-An index to genera and species: Canadian Technical Reports on Hydrography and Ocean Science, v. 67, p. 1-F45.

Delcourt, A. F., and Sprumont, G., 1955, Les spores et grains de pollen du Wealdien du Hainaut: Memoires de Societe de Belgium Géologique, n.s., v. 4, p. 1-73.

Dörhöfer, G., 1977, Palynologie und Stratigraphie der Bückerberg Formation (Berriasium-Valanginium) in der Hilsmunde (NWDeutschland): Geol. Jb., Part A, v. 42, p. 3-122.

Dutton, A., Wilkinson, B. H., Welker, J. M., Bowen, G. J., and Lohmann, K. C., 2005, Spatial distribution and seasonal variation in ${ }^{18} \mathrm{O} /{ }^{16} \mathrm{O}$ of modern precipitation and river water across the conterminous USA: Hydrological Processes, v. 19, p. 4,121-4,146.

Espitalie, J., Madec, M., and Tissot, B., 1977, Source rock characterization method for petroleum exploration, OTC 2935: $9^{\text {th }}$ Annual Offshore Technology Conference, Houston, Texas, p. 439-444.

Franks, P. C., 1975, The transgressive-regressive sequence of the Cretaceous Cheyenne, Kiowa, and Dakota formations of Kansas; in, The Cretaceous System in the Western Interior of North America, W. G. E. Caldwell, ed.: Geological Association of Canada, Special Paper 13, p. 469-521.

Franks, P. C., 1979, Paralic to fluvial record of an Early Cretaceous marine transgression, Longford Member, Kiowa Formation: Kansas Geological Survey, Bulletin 219, 55 p.

Graham, J. P., 2000, Revised stratigraphy, depositional systems, and hydrocarbon exploration potential for the Lower Cretaceous Muddy Sandstone, northern Denver basin: American Association of Petroleum Geologists, Bulletin, v. 84, p. 183-209.
Gröcke, D. R., Ludvigson, G. A., Witzke, B. J., Robinson, S. A., Joeckel, R. M., Ufnar, D. F., and Ravn, R. L., 2006, Recognizing the Albian-Cenomanian (OAE1d) sequence boundary using plant carbon isotopes - Dakota Formation, Western Interior basin, USA: Geology, v. 34, no. 3, p. 193-196.

Hamilton, V., 1994, Sequence stratigraphy of Cretaceous Albian and Cenomanian strata in Kansas; in, Perspectives on the Eastern Margin of the Cretaceous Western Interior Basin, G. W. Shurr,

G. A. Ludvigson, and R. H. Hammond, eds.: Geological Society of America, Special Paper 287, p. 79-96.

Hart, B. S., Longstaffe, F. J. and Plint, A. G., 1992, Evidence for relative sea level changes from isotope and elemental composition of siderite in the Cardium Formation, Alberta: Bulletin of Canadian Petroleum Geology, v. 40, p. 52-59.

Hattin, D. E., 1967, Stratigraphic and paleoecologic significance of macroinvertebrate fossils in the Dakota Formation (Upper Cretaceous) of Kansas; in, Essays in Paleontology and StratigraphyR. C. Moore Commemorative Volume, C. Teichert and E. L. Yochelson, eds.: University of Kansas, Department of Geology, Special Publication 2, p. 570-589.

Hays, P. D., and Grossman, E. L., 1991, Oxygen isotopes in meteoric calcite cements as indicators of continental paleoclimate: Geology, v. 19, p. 441-444.

Hedlund, R. W., 1966, Palynology of the Red Branch Member (Woodbine Formation): Oklahoma Geological Survey, Bulletin 112, p. $1-69$.

Holbrook, J., 2001, Origin, genetic interrelationships, and stratigraphy over the continuum of fluvial channel-form bounding surfaces-An illustration from middle Cretaceous strata, southeastern Colorado: Sedimentary Geology, v. 144, p. 179-222.

Holbrook, J., Scott, R. W., Oboh-Ikuenobe, F., Evetts, M., and Akins, S., 2002, Sequence stratigraphic and paleoecologic lowstand model of ephemeral connections in epeiric seaways, U.S. Western Interior Cretaceous: American Association of Petroleum Geologists, Annual Meeting Expanded Abstracts, v. 2002, p. 79.

Holbrook, J., Scott, R. W., and Oboh-Ikuenobe, F. E., 2006, Base-level buffers and buttresses - A model for upstream versus downstream control on fluvial geometry and architecture within sequences: Journal of Sedimentary Research, v. 76, p. 162-174.

Houseknecht, D. W., 1987, Assessing the relative importance of compaction processes and cementation to reduction of porosity in sandstones: American Association of Petroleum Geologists, Bulletin, v. 71, p. 633-642.

Joeckel, R. M., 1987, Paleogeomorphic significance of two paleosols in the Dakota Formation (Cretaceous), southeastern Nebraska: University of Wyoming, Contributions to Geology, v. 25, no. 2, p. 95-102.

Joeckel, R. M., Cunningham, J. M., Corner, R. G., Brown, G. W., Phillips, P. L., and Ludvigson, G. A., 2004, Late Albian dinosaur tracks from the cratonic (eastern) margin of the Western Interior seaway, Nebraska, USA: Ichnos, v. 11, p. 275-284.

Joeckel, R. M., Ludvigson, G. A., Witzke, B. J., Kvale, E. P., Phillips, P. L., Brenner, R. L., Thomas, S. G., and Howard, L. M., 2005, Palaeogeography and fluvial to estuarine architecture of the Dakota Formation (Cretaceous, Albian), eastern Nebraska, USA; in, Fluvial Sedimentology VII, M. D. Blum and S. B. Marriott, eds.: Blackwell, Oxford, p. 453-480.

Joeckel, R. M., Ludvigson, G. A., and Macfarlane, P. A., 2007, Field Trip 2-Fluvial-estuarine deposition in the mid-Cretaceous Dakota Formation, Kansas and Nebraska: Kansas Geological Survey, Open-file Report 2008-2, 30 p.

Kauffman, E. G., Sageman, B. B., Kirkland, L. I., Elder, W. P., Harries, P. J., and Villamil, T., 1993, Molluscan biostratigraphy of the Cretaceous Western Interior basin, North America; in, Evolution of 
the Western Interior Basin, W. G. E. Caldwell and E. G. Kauffman, eds.: Geological Association of Canada, Special Paper 39, p. 397-434.

Korus, J. T., 2000, Estuarine deposition and tidal rhythmites of the Dakota Formation (upper Albian), southeastern Nebraska: Nebraska Academy of Sciences, Annual Meeting Program and Proceedings, v. 110 , p. 67.

Kvale, E. P., and Archer, A. W., 2007, Paleovalley fills-Trunk vs. tributary: American Association of Petroleum Geologists, Bulletin, v. 91, no. 6, p. 809-821.

Laenen, B., and DeCraen, M., 2004, Eogenetic siderite as an indicator for fluctuations in sedimentation rate in the Oligocene Boom Clay Formation (Belgium): Sedimentary Geology, v. 163, p. 165-174.

Lockley, M., Holbrook, J., Kukihara, R., and Matsukawa, M., 2006, An ankylosaur-dominated dinosaur tracksite in the Cretaceous Dakota Group of Colorado-Paleoenvironmental and sequence stratigraphic context; in, Late Cretaceous Vertebrates from the Western Interior, S. G. Lucas and R. M . Sullivan, eds.: New Mexico Museum of Natural History and Science, Bulletin 35, p. 95-104.

Lohmann, K. C., 1988, Geochemical patterns of meteoric diagenetic systems and their application to studies of paleokarst; in, Paleokarst, N. P. James and P. W. Choquette, eds.: Springer-Verlag, p. 58-80.

Ludvigson, G. A., 1999, Compositional differences between Jurassic and Cretaceous sandstones of western Iowa, with comments on the controlling factors: Geological Society of Iowa, Guidebook 67, p. 45-53.

Ludvigson, G. A., Witzke, B. J., González, L. A., Brenner, R. L., Joeckel, R. M., Hammond, R. H., and Ravn, R. L., 1995, Toward an AlbianCenomanian spherosiderite chemostratigraphy in the Dakota Formation of the type area, NW Iowa and NE Nebraska: Geological Society of America, Abstracts with Programs, v. 27, no. 3, p. 70.

Ludvigson, G. A., and Witzke, B. J., 1996, Introduction; in, Mid-Cretaceous Fluvial Deposits of the Eastern Margin, Western Interior Basin-Nishnabotna Member, Dakota Formation, B. J. Witzke and G. A. Ludvigson, eds.: Iowa Department of Natural Resources, Geological Survey Bureau, Guidebook Series No. 17, p. 1-6.

Ludvigson, G. A., González, L. A., Witzke, B. J., Brenner, R. L., and Metzger, R. A., 1996, Diagenesis of iron minerals in the Dakota Formation; in, Mid-Cretaceous Fluvial Deposits of the Eastern Margin, Western Interior Basin - Nishnabotna Member, Dakota Formation, B. J. Witzke and G. A. Ludvigson, eds.: Iowa Department of Natural Resources, Geological Survey Bureau, Guidebook Series No. 17, p. 31-38.

Ludvigson, G. A., Witzke, B. J., Kvale, E. P, Brenner, R. L., White, T. S., Gonzalez, L. A., and Joeckel, R. M., 1998, Mid-Cretaceous shorelines of the cratonic margin, Western Interior basin - Where have all the deltas gone?: Geological Society of America, Abstracts with Programs, v. 30, no. 2, p. 57.

Ludvigson, G. A., González, L. A., Metzger, R. A., Witzke, B. J., Brenner, R. L., Murillo, A. P., and White, T. S.,1998, Meteoric spherosiderite lines and their use for paleohydrology and paleoclimatology: Geology, v. 26, p. 1,039-1,042.

Macfarlane, P. A., Whittemore, D. O., Doveton, J. H., Chu, T.-m., Smith, M., and Feldman, H., 1993, The Dakota Aquifer Program Annual Report, FY93: Kansas Geological Survey, Open-file Report 94-1, $115 \mathrm{p}$.

Meek, F. B., and Hayden, F. V., 1862, Descriptions of Lower Silurian (Primordial), Jurassic, Cretaceous, and Tertiary fossils, collected in Nebraska by the exploring expedition under the command of Captain Wm. F. Reynolds, U.S. Topographic Engineers, with some remarks on the rocks from which they were obtained: Philadelphia Academy National Science Proceedings, v. 13, p. 415-447.

Moore, W. S., 1996, Large ground water inputs to coastal waters revealed by ${ }^{226} \mathrm{Ra}$ enrichments: Nature, v. 380, p. 612-614.
Moore, W. S., 1999, The subterranean estuary-A reaction zone of ground water and seawater: Marine Chemistry, v. 65, p. 111-125.

Mozley, P., 1989, Relation between depositional environment and the elemental composition of early diagenetic siderite: Geology, v. 17, p. 704-706.

Nichols, D. J., and Jacobson, S. R., 1982, Palynostratigraphic framework for the Cretaceous (Albian-Maestrichtian) of the Overthrust Belt of Utah and Wyoming: Palynology, v. 6, p. 119-147.

Norris, G., 1967, Spores and pollen from the Lower Colorado Group (Albian-?Cenomanian) of central Alberta: Palaeontographica B, v. 120, p. 72-115.

Norris, G., 1969, Miospores from the Purbeck Beds and Upper Jurassic of southern England: Palaeontology, v. 12, p. 574-620.

Norvick, M. S., and Burger, D., 1976, Palynology of the Cenomanian of Bathurst Island, Northern Territory, Australia: Australian Bureau of Mineral Resources, Geology and Geophysics Bulletin, v. 151, p. $1-169$.

Oboh-Ikuenobe, F. E., Scott, R. W., Holbrook, J. M., Evetts, M. J., Akins, S. L., and Benson, D. G., 2004, Models of epeiric seaway connections-Middle Cretaceous of the U.S. Western Interior: Geological Society of America, Abstracts with Programs, v. 36, no. 3, p. 14.

Oboh-Ikuenobe, F. E., Benson, D. G., Scott, R.W., Holbrook, J. M., Evetts, M. J., and Erbacher, J., 2007, Re-evaluation of the AlbianCenomanian boundary in the U.S. Western Interior based on dinoflagellate cysts: Review of Paleobotany and Palynology, v. 144, p. 77-97.

Paxton, S. T., Szabo, J. O., Ajdukiewicz, J. M., and Klimentidis, R. E., 2002 , Construction of an intergranular volume compaction curve for evaluating and predicting compaction and porosity loss in rigidgrain sandstone reservoirs: American Association of Petroleum Geologists, Bulletin, v. 86, p. 2,047-2,067.

Phillips, P. L., Jr., 2004, Paleohydrologic and stratigraphic implications of early diagenetic carbonate cements - Examples from marginal marine deposits of the Cretaceous Western Interior seaway: Ph.D. dissertation, University of Iowa, Iowa City, 186 p.

Phillips, P. L., Jr., Ludvigson, G. A., Joeckel, R. M., Gonzalez, L. A., Brenner, R. L., and Witzke, B. J., 2003, The role of synsedimentary carbonate cementation in the preservation of dinosaur track sitesAn example from the Dakota Formation: Society of Vertebrate Paleontologists, Abstracts, Journal of Vertebrate Paleontology, v. 23, no. 3 suppl., p. 87A.

Phillips, P. L., Jr., and White, T. S., 1998, Preliminary description and discussion of facies of the Nishnabotna Member of the Dakota Formation, Guthrie County, Iowa; in, The Natural History of Springbrook State Recreation Area, Guthrie County, Iowa, R. R. Anderson and B. J. Bunker, eds.: Geological Society of Iowa, Guidebook 66, p. 65-69.

Phillips, P. L., Ludvigson, G. A., Joeckel, R. M., González, L. A., Brenner, R. L., and Witzke, B. J., 2007, Sequence stratigraphic controls on synsedimentary cementation and preservation of dinosaur tracks - Example from the lower Cretaceous (Upper Albian) Dakota Formation, southeastern Nebraska, USA: Palaeogeography, Palaeoclimotology, Palaeoecology, v. 246, p. 367-389.

Phillips, P. P., and Felix, C. J., 1972a, A study of Lower and Middle Cretaceous spores and pollen from the southeastern United States-I. Spores: Pollen et Spores, v. 13 (1971), p. 280-348.

Phillips, P. P., and Felix, C. J., 1972b, A study of Lower and Middle Cretaceous spores and pollen from the southeastern United States-II. Pollen: Pollen et Spores, v. 13 (1971), p. 447-473.

Pierce, R. L., 1961, Lower Upper Cretaceous plant microfossils from Minnesota: Minnesota Geological Survey, Bulletin 42, p. 1-86.

Playford, G., 1971, Palynology of Lower Cretaceous (Swan River) strata of Saskatchewan and Manitoba: Palaeontology, v. 14, p. 533-565. 
Pocock, S. A. J., 1962, Microfloral analysis and age determination of strata at the Jurassic-Cretaceous boundary in the Western Canada Plains: Palaeontographica, Part B, v. 111, p. 1-95.

Potonié, R., 1956, Synopsis der Gattungen des Sporae dispersae, Teil I: Sporites. Beih. Geol. Jb., v. 23, p. 1-103.

Ravn, R. L., 1986, Microreticulatisporites sacalii (Déak \& Combaz) n. comb., a stratigraphically significant miospore from the Cenomanian of the United States: Journal of Paleontology, v. 60, p. 772-777.

Ravn, R. L., 1995, Miospores from the Muddy Sandstone (upper Albian), Wind River basin, Wyoming, U.S.A.: Palaeontographica (Beiträge zur Naturgeschichte der Vorzeit, Stuttgart), Abt. B, v. 234, p. 41-91.

Ravn, R. L., 1981, Preliminary observations on the palynology of upper Dakota lignites from northwestern Iowa and northeastern Nebraska; in, Cretaceous Stratigraphy and Sedimentation in Northwest Iowa, Northeast Nebraska, and Southeast South Dakota: Iowa Geological Survey, Guidebook Series, no. 4, p. 123-127.

Ravn, R. L., and Witzke, B. J., 1994, The mid-Cretaceous boundary in the Western Interior seaway, central United States - Implications of palynostratigraphy from the type Dakota Formation; in, Perspectives on the Eastern Margin of the Cretaceous Western Interior Basin, G. W. Shurr, G. A. Ludvigson, and R. H. Hammond, eds.: Geological Society of America, Special Paper 287, p. 111-128.

Ravn, R. L., and Witzke, B. J., 1995, The palynostratigraphy of the Dakota Formation (?late Albian-Cenomanian) in its type area, northwestern Iowa and northeastern Nebraska, USA: Palaeontographica (Beiträge zur Naturgeschichte der Vorzeit, Stuttgart), Abt. B, v. 234, p. 93-171.

Reeside, J. B., and Cobban, W. A., 1960, Studies of the Mowry Shale (Cretaceous) and contemporary formations in the United States and Canada: U.S. Geological Survey, Professional Paper 355, 126 p.

Romans, R. C., 1975, Palynology of some Upper Cretaceous coals of Black Mesa, Arizona: Pollen et Spores, v. 17, p. 273-329.

Rozanski, K., Araguas-Araguas, L., and Gonfiantini, R., 1993, Isotopic patterns in modern global precipitation; in, Climate Change in Continental Isotopic Records, P. K. Swart et al., eds.: American Geophysical Union, Geophysical Monograph 78, p. 1-36.

Scott, R. W., Franks, P. C., Evetts, M. J., Bergen, J. A., and Stein, J. A., 1998, Timing of mid-Cretaceous relative sea level changes in the Western Interior-Amoco No. 1 Bounds core; in, Stratigraphy and Paleoenvironments of the Cretaceous Western Interior Seaway, U.S.A., W. E. Dean and M. A. Arthur, eds.: SEPM, Concepts in Sedimentology and Paleontology, no. 6, p. 11-34.

Scott, R. W., Holbrook, J. M., Evetts, M. J., and Oboh-Ikuenobe, F. E., 2001, Albian-Cenomanian depositional cycles transgressed from Chihuahua trough to Western Interior: New Mexico Geological Society, Guidebook, 52 ${ }^{\text {nd }}$ Field Conference, p. 221-228.

Scott, R. W., Holbrook, J. M., Oboh-Ikuenobe, F. E., Evetts, M. J., Benson, D. G., and Kues, B. S., 2004, Middle Cretaceous stratigraphy, southern Western Interior seaway, New Mexico and Oklahoma: The Mountain Geologist, v. 41, p. 33-59.

Singh, C., 1964, Microflora of the Lower Cretaceous Mannville Group, east-central Alberta: Alberta Research Council, Bulletin 15, p. $1-239$.

Singh, C., 1971, Lower Cretaceous microfloras of the Peace River area, northwestern Alberta: Alberta Research Council, Bulletin 28, p. $1-542$.

Singh, C., 1983, Cenomanian microfloras of the Peace River area, northwestern Alberta: Alberta Research Council, Bulletin 44, p. 1-322.

Slingerland, R., Kump, L. R., Arthur, M. A., Fawcett, P. J., Sageman, B. B., and Barron, E. J., 1996, Estuarine circulation in the Turonian Western Interior seaway of North America: Geological Society of America Bulletin, v. 108, p. 941-952.
Srivastava, S. K., 1977, Microspores from the Fredericksburg Group (Albian) of the southern United States: Paléobiologie Continentale, v. 6, p. 1-119.

Stover, L. E., 1962, Taurocusporites, a new trilete spore genus from the Lower Cretaceous of Maryland: Micropaleontology, v. 8, p. 1-28.

Taylor, K. G., Gawthrope, R. L., and van Wagoner, J. C., 1995, Stratigraphic control on laterally persistent cementation, Book Cliffs, Utah: Journal of the Geological Society, London, v. 152, p. 225-228.

Taylor, K. G., Gawthorpe, R. L., Curtis, C. D., Marshall, J. D., and Awwiller, D. N., 2000, Carbonate cementation in a sequencestratigraphic framework - Upper Cretaceous sandstones, Book Cliffs, Utah-Colorado: Journal of Sedimentary Research, v. 70, p. 360-372.

Tester, A. C., 1931, The Dakota Stage of the type locality: Iowa Geological Survey, Annual Report, v. 35, p. 197-332.

Tibert, N. E., and Leckie, R. M., 2004, High-resolution estuarine sea level cycles from the Late Cretaceous-Amplitude constraints using agglutinated foraminifera: Journal of Foraminiferal Research, v. 34, no. 2, p. 130-143.

Ufnar, D. F., Gonzalez, L. A., Ludvigson, G. A., Brenner, R. L., and Witzke, B. J., 2001, Statigraphic implications of meteoric spherosiderite $\delta^{18} \mathrm{O}$ values in paleosols of the Cretaceous (Albian) Boulder Creek Formation, NE British Columbia foothills, Canada: Journal of Sedimentary Research, v. 71, p. 1,017-1,028.

Ufnar, D. F., González, L. A., Ludvigson, G. A., Brenner, R. L., and Witzke, B. J., 2002, The mid-Cretaceous water bearer-Isotope mass balance quantification of the Albian hydrologic cycle: Palaeogeography, Palaeoclimatology, Palaeoecology v. 188, p. 51-71.

Ufnar, D. F., González, L. A., Ludvigson, G. A., Brenner, R. L., and Witzke, B. J., 2004a, Diagenetic overprinting of the spherosiderite paleoclimate proxy-Are records of pedogenic ground-water $\delta^{18} \mathrm{O}$ values preserved?: Sedimentology, v. 51, no. 1, p. 127-144.

Ufnar, D. F., González, L. A., Ludvigson, G. A., Brenner, R. L., and Witzke, B. J., 2004b, Evidence for increased latent heat transport during the Cretaceous (Albian) greenhouse warming: Geology, v. 32, no. 12, p. 1,049-1,052.

Upchurch, G. R., Jr., and Dilcher, D. L., 1990, Cenomanian angiosperm leaf megafossils, Dakota Formation, Rose Creek locality, Jefferson County, southeastern Nebraska: U.S. Geological Survey, Bulletin $1915,55 \mathrm{p}$.

van Hengstum, P. J., Reinhardt, E. G., Medioli, F. S., and Gröcke, D. R., 2007, Exceptionally preserved Late Albian (Cretaceous) Arcellaceans (Thecamoebians) from the Dakota Formation near Lincoln, Nebraska, USA: Journal of Foraminiferal Research, v. 37, no. 4, p. 300-308.

Venkatachala, B. S., Kar, R. K., and Raza, S., 1969, Palynology of the Mesozoic sediments of Kutch, W. India; 3-Morphological study and revision of the spore genus Trilobosporites Pant ex Potonié 1956: Palaeobotanist, v. 17 (1968), p. 123-126.

Ward, C. R., 2002, Analysis and significance of mineral matter in coal seams: International Journal of Coal Geology, v. 50, p. 135-168.

Ward, J. V., 1986, Early Cretaceous angiosperm pollen from the Cheyenne and Kiowa Formations (Albian) of Kansas, U.S.A.: Palaeontographica B, v. 202, p. 3-81.

Weyland, H., and Krieger, W., 1953, Die Sporen und Pollen der Aachener Kreide und ihre Bedeutung fur die Charakterisierung des mittleren Senons: Palaeontographica Abteilung B, v. 95, p. 6-29.

White, T. S., Witzke, B. J., and Ludvigson, G. A., 2000, Evidence for an Albian Hudson Arm connection between the Cretaceous Western Interior seaway of North America and the Labrador Sea: Geological Society of America Bulletin, v. 112, p.1,342-1,355.

White, T., González, L., Ludvigson, G., and Poulsen, C., 2001, Middle Cretaceous greenhouse hydrologic cycle of North America: Geology, v. 29, no. 4, p. 363-366. 
White, T., Witzke, B., Ludvigson, G., and Brenner, R., 2005, Distinguishing base-level change and climate signals in a Cretaceous alluvial sequence: Geology, v. 33, p. 13-16.

Whitley, D. L., and Brenner, R. L., 1981, Subsurface stratigraphic and sedimentologic analyses of Cretaceous rocks in northwest Iowa: Iowa Geological Survey, Guidebook Series No. 4, p. 57-75.

Wingate, F. H., 1980, Plant microfossils from the Denton Shale Member of the Bokchito Formation (Lower Cretaceous, Albian) in southern Oklahoma: Oklahoma Geological Survey, Bulletin 130, p. 1-93.

Wingate, F. E., 1983, Palynology and age of the Elko Formation (Eocene) near Elko, Nevada: Palynology, v. 7, p. 93-132.

Witzke, B. J., 2007, What, if anything, is the "Muddy Cycle" (Late Albian) in the Western Interior?: Geological Society of America, Abstracts with Programs, v. 39, no. 3, p. 75.

Witzke, B. J. and Ludvigson, G. A., 1982, Cretaceous stratigraphy and depositional systems in Guthrie County, Iowa: Geological Society of Iowa, Guidebook 38, 46 p.

Witzke, B. J., and Ludvigson, G. A., 1987, Cretaceous exposures, Big Sioux River valley north of Sioux City, Iowa: Geological Society of America, Centennial Field Guide, North-central Section, p. 97-102.

Witzke, B. J., and Ludvigson, G. A., 1994, The Dakota Formation in Iowa and the type area; in, Perspectives on the Eastern Margin of the Cretaceous Western Interior Basin, G. W. Shurr, G. A. Ludvigson, and R. H. Hammond, eds.: Geological Society of America, Special Paper 287, p. 43-78.

Witzke, B. J., and Ludvigson, G. A., 1996, Coarse-grained eastern facies; in, Mid-Cretaceous Fluvial Deposits of the Eastern Margin, Western Interior Basin - Nishnabotna Member, Dakota Formation, B. J. Wizke and G. A. Ludvigson, eds.: Iowa Department of Natural Resources, Geological Survey Bureau, Guidebook Series No. 17, p. 19-30.

Witzke, B. J., and Ludvigson, G. A., 1998, Cretaceous bedrock geology in the Springbrook area; in, The Natural History of Springbrook State Recreation Area, Guthrie County, Iowa, R. R. Anderson and B. J. Bunker, eds.: Geological Society of Iowa, Guidebook 66, p. 13-19.

Witzke, B. J., Ludvigson, G. A., Ravn, R. L., and Poppe, J. R., 1983, Cretaceous paleogeography along the eastern margin of the Western Interior seaway, Iowa, southern Minnesota, and eastern Nebraska and South Dakota; in, Mesozoic Paleogeography of the WestCentral United States, M. W. Reynolds and E. D. Dolly, eds.: Rocky Mountain Paleogeography Symposium 2, Society of Economic Paleontologists and Mineralogists, Rocky Mountain Section, Denver, p. 225-252.

Witzke, B. J., Ravn, R. L., Ludvigson, G. A., Joeckel, R. M., and Brenner, R. L., 1996, Age and correlation of the Nishnabotna Member; in, Mid-Cretaceous Fluvial Deposits of the Eastern Margin, Western Interior Basin - Nishnabotna Member, Dakota Formation, B . J. Witzke and G. A. Ludvigson, eds.: Iowa Department of Natural Resources, Geological Survey Bureau, Guidebook Series No. 17, p. 13-18.

Witzke, B. J., Ludvigson, G. A., Ravn, R. L., Brenner, R. L., and Joeckel, R. M., 1996, Palynostratigraphic framework for mid-Cretaceous strata, eastern margin of Western Interior basin: Geological Society of America, Abstracts with Programs, v. 28, no. 7, p. 185.

Witzke, B. J., Ludvigson, G. A., Brenner, R. L., and Joeckel, R. M., 1996, Regional Dakota sedimentation; in, Mid-Cretaceous Fluvial Deposits of the Eastern Margin, Western Interior BasinNishnabotna Member, Dakota Formation, B. J. Witzke and G. A. Ludvigson, eds.: Iowa Department of Natural Resources, Geological Survey Bureau, Guidebook Series No. 17, p. 7-11.

Witzke, B. J., Ludvigson, G. A., and Day, J., 1996, Introduction -Paleozoic applications of sequence stratigraphy; in, Paleozoic Sequence Stratigraphy, B. J. Witzke, G. A. Ludvigson, and J. Day, eds.: Geological Society of America, Special Paper 306, p. 1-6.

Witzke, B. J., Ludvigson, G. A., White, T. S., and Brenner, R. L., 1999, Marine-influenced sedimentation in the Dakota Fm., Cretaceous (Albian-Cenomanian), central U.S.-Implications for sequence stratigraphy and paleogeography in the Western Interior: Geological Society of America, Abstracts with Programs, v. 31, no. 6, p. 426.

Young, L. D., 2002, High resolution chemostratigraphic correlations and the development of accommodation space in mid-Cretaceous strata, eastern margin Western Interior seaway, central United States: M.S. thesis, University of Iowa, Iowa City, 175 p.

Zawistoski, A. N., Kvale, E. P., and Ludvigson, G. A., 1996, Upper Albian (basal Dakota Fm.) tidal rhythmites, eastern Nebraska: Geological Society of America, Abstracts with Programs, v. 28, no. 6,p. 73. 
PLATE 1-All micrographs are at x625 magnification.

1. Lycopodiacidites arcuatus Hedlund 1966; Cenomanian, Iowa.

2. Microfoveolatosporis pseudoreticulatus (Hedlund) Singh 1983; late Albian, Nebraska.

3. Microreticulatisporites sacalii (Deák and Combaz) Ravn 1986; Cenomanian, Iowa.

4. Scopusporis excavatus (Brenner) Wingate 1980; late Albian, Nebraska.

5. Plicatella jansonii (Pocock) Dörhöfer 1977; late Albian, Nebraska.

6. Staplinisporites caminus (Balme) Pocock 1962; late Albian, Nebraska.

7. Plicatella unica (Markova) Dörhöfer 1977; late Albian, Nebraska.

8. Neoraistrickia robusta Brenner 1963; late Albian, Nebraska.

9. Equisetosporites concinnus Singh 1964; late Albian, Kansas.

10. Granulatisporites michinus (Srivastava) Ravn and Witzke 1995; late Albian, Kansas.

11. Plicatella witzkei Ravn 1995; late Albian, Nebraska.

12. Plicatella cristata (Markova) Davies 1985; Cenomanian, Iowa.

13. Camarozonosporites wrennii Ravn 1995; late Albian, Kansas.

14. Impardecispora excavata Ravn 1995; late Albian, Nebraska.

15. Pilosisporites trichopapillosus (Thiergart) Delcourt and Sprumont 1955; late Albian, Nebraska. 


\section{Plate 1}
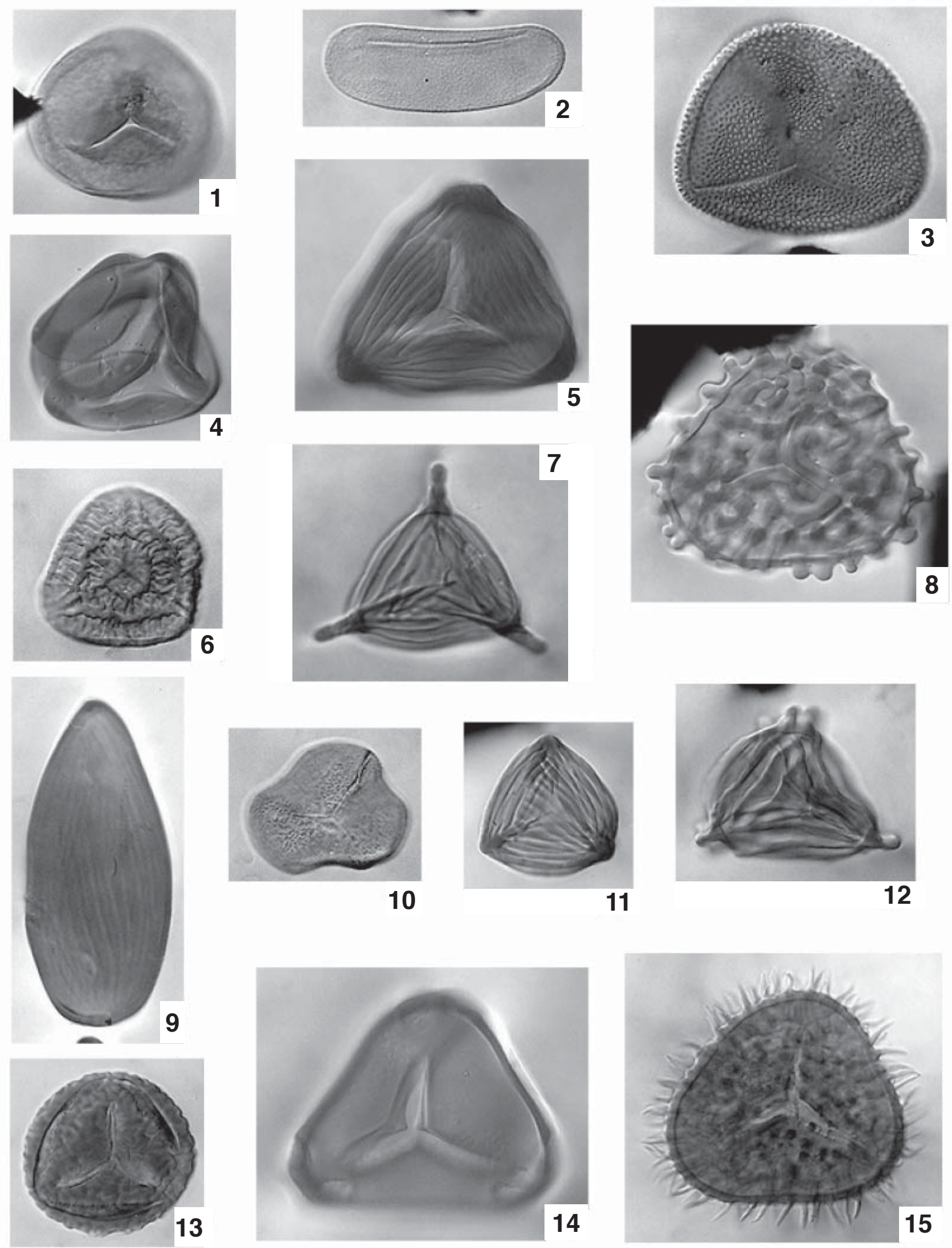

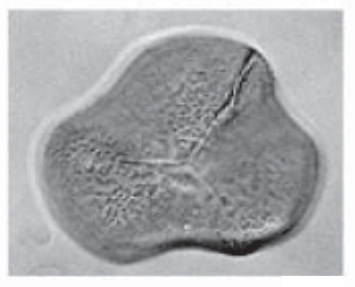

10

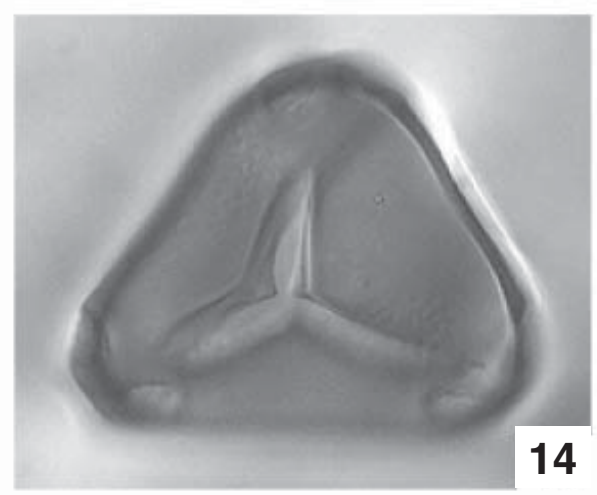

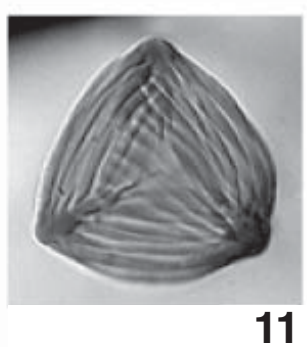

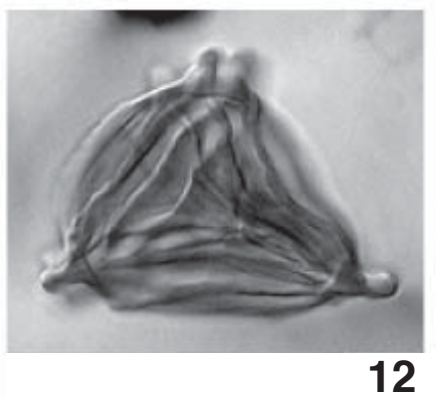

11

12

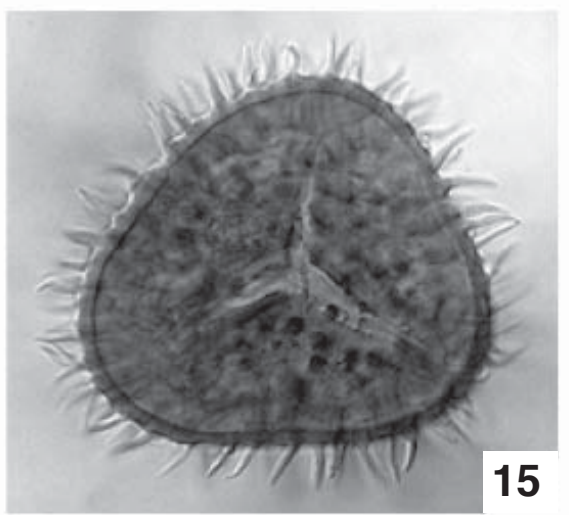


PLATE 2-All micrographs are at x625 magnification.

1. Tigrisporites verrucatus Singh 1983; late Albian, Kansas.

2. Callialasporites dampieri (Balme) Dev emend. Norris 1969; late Albian, Nebraska.

3. Quadricolpites reticulatus Wingate 1983; late Albian, Nebraska.

4. Quadricolpites reticulatus Wingate 1983; late Albian, Kansas.

5. Taurocusporites segmentatus Stover 1962; late Albian, Nebraska.

6. Nicholsipollis mimas Ravn 1995; late Albian, Nebraska.

7. Schizaeoisporites eocenicus (Selling) Potonié 1956, sensu Singh 1964; late Albian, Nebraska.

8. Cicatricosisporites crassiterminatus Hedlund 1966; Cenomanian, Iowa.

9. Jiaohepollis sp.; late Albian, Nebraska.

10. Stellatopollis barghoornii Singh 1983; late Albian, Nebraska.

11. Densoisporites velatus Weyland and Krieger 1953; late Albian, Nebraska.

12. Foveogleicheniidites confossus (Hedlund) Burger, in Norvick and Burger, 1976; Cenomanian, South Dakota.

13. Ischyosporites disjunctus Singh 1971; late Albian, Kansas.

14. Cicatricosisporites patapscoensis Brenner 1963; late Albian, Nebraska.

15. Impardecispora apiverrucata (Couper) Venkatachala, Kar, and Raza 1969; late Albian, Kansas.

16. Balmeiopsis limbatus (Balme) Archangelsky 1977; late Albian, Kansas. 


\section{Plate 2}
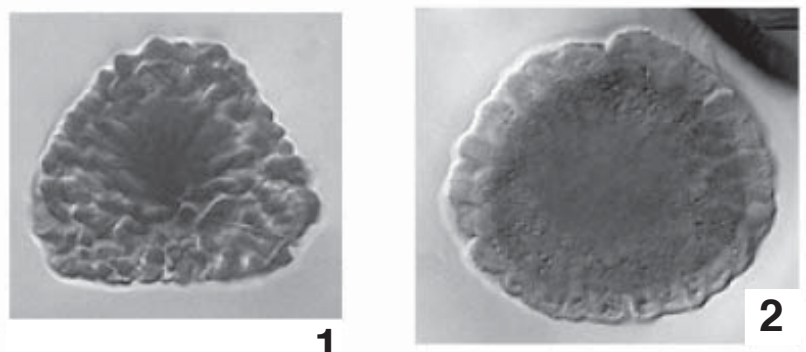

1
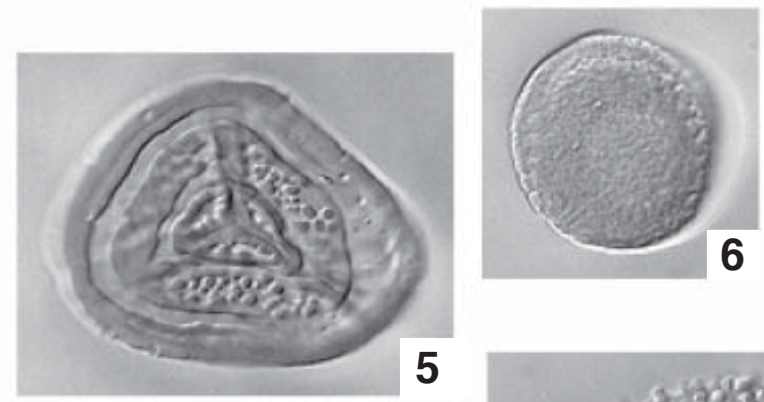

5
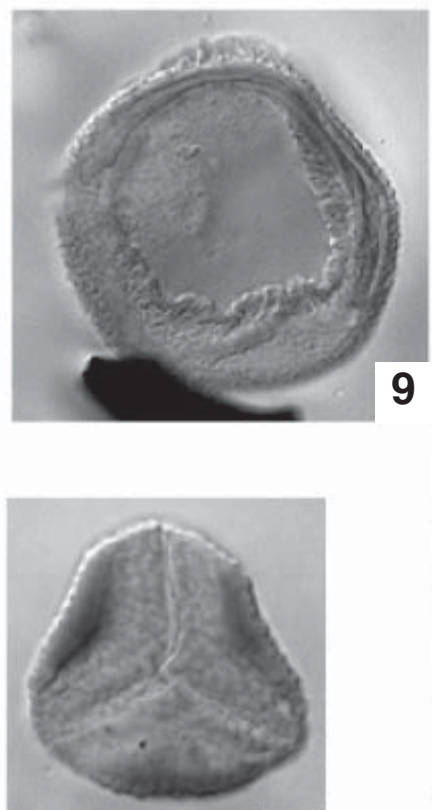

12

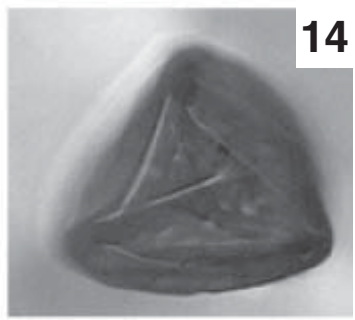

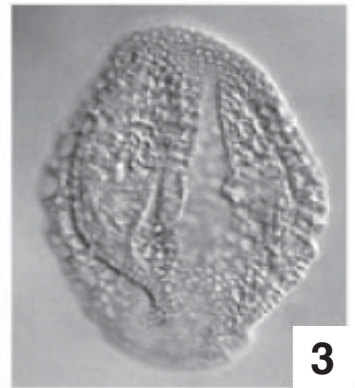

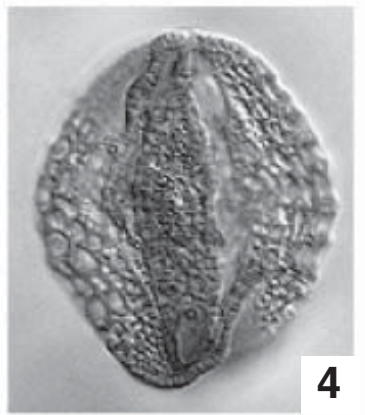

4
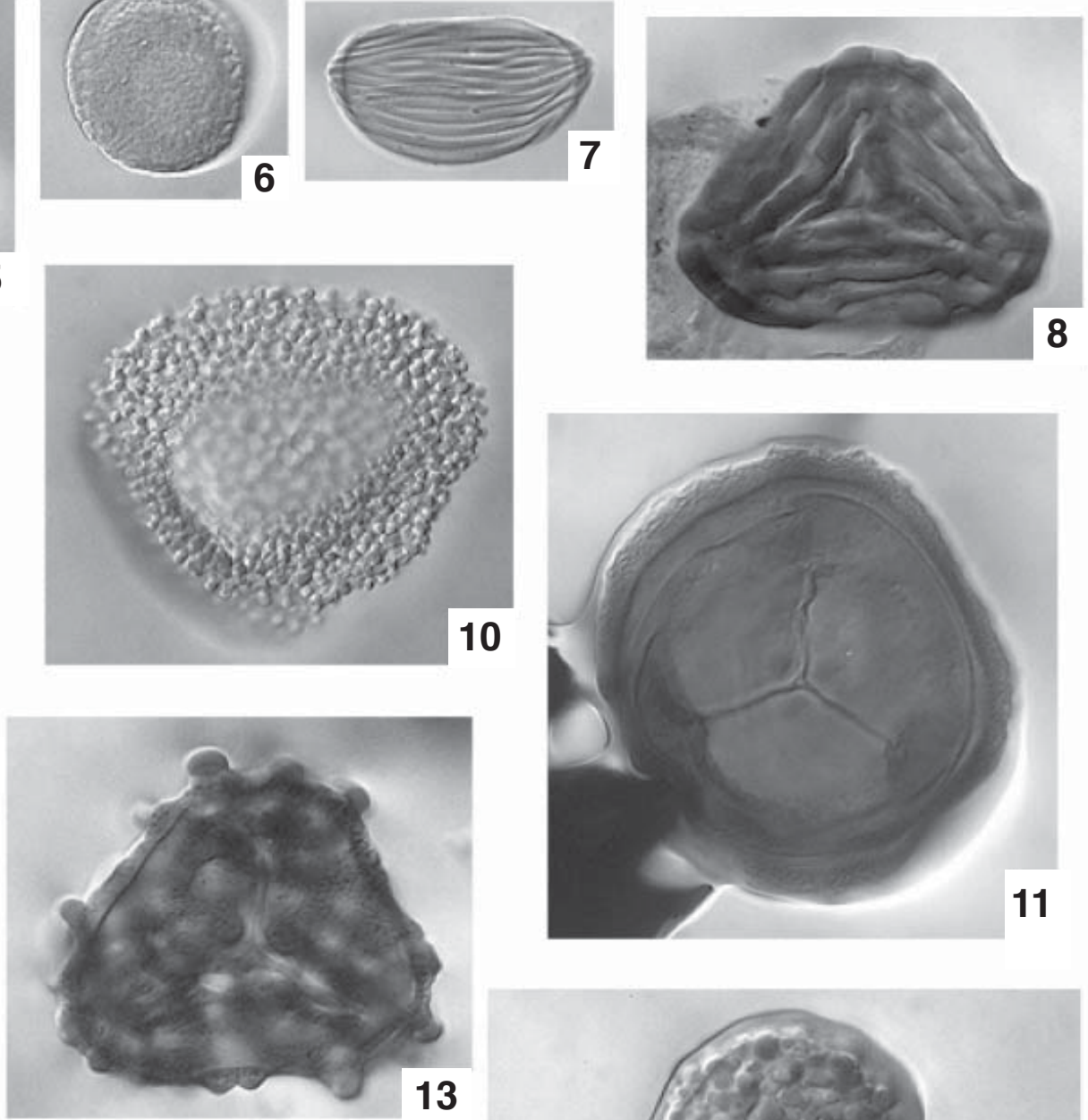

13

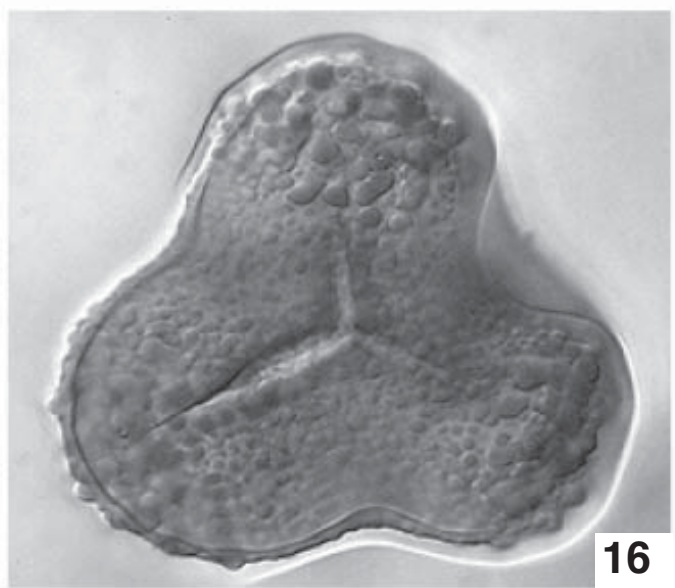

Current Research in Earth Sciences, Bulletin 258, part 2 (http://www.kgs.ku.edu/Current/2010/Ludvigson/index.html) 